Florida International University

FIU Digital Commons

$3-25-2020$

\title{
Adoption, Stringency and Impact of Performance Management Systems: The Case of U.S. Public Higher Education
}

\author{
Lilia Silverio Minaya \\ Florida International University, Isilveri@fiu.edu
}

Follow this and additional works at: https://digitalcommons.fiu.edu/etd

Part of the Public Affairs Commons

\section{Recommended Citation}

Silverio Minaya, Lilia, "Adoption, Stringency and Impact of Performance Management Systems: The Case of U.S. Public Higher Education" (2020). FIU Electronic Theses and Dissertations. 4422.

https://digitalcommons.fiu.edu/etd/4422

This work is brought to you for free and open access by the University Graduate School at FIU Digital Commons. It has been accepted for inclusion in FIU Electronic Theses and Dissertations by an authorized administrator of FIU Digital Commons. For more information, please contact dcc@fiu.edu. 


\title{
FLORIDA INTERNATIONAL UNIVERSITY
}

Miami, Florida

\section{ADOPTION, STRINGENCY AND IMPACT OF PERFORMANCE MANAGEMENT SYSTEMS: THE CASE OF U.S. PUBLIC HIGHER EDUCATION}

A dissertation submitted in partial fulfillment of

\author{
the requirements for the degree of \\ DOCTOR OF PHILOSOPHY \\ in
}

PUBLIC AFFAIRS

by

Lilia Silverio-Minaya

2020 
To: Dean John F. Stack, Jr.

Steven J. Green School of International and Public Affairs

This dissertation, written by Lilia Silverio-Minaya, and entitled Adoption, Stringency and Impact of Performance Management Systems: The Case of U.S. Public Higher

Education, having been approved in respect to style and intellectual content, is referred to you for judgment.

We have read this dissertation and recommend that it be approved.

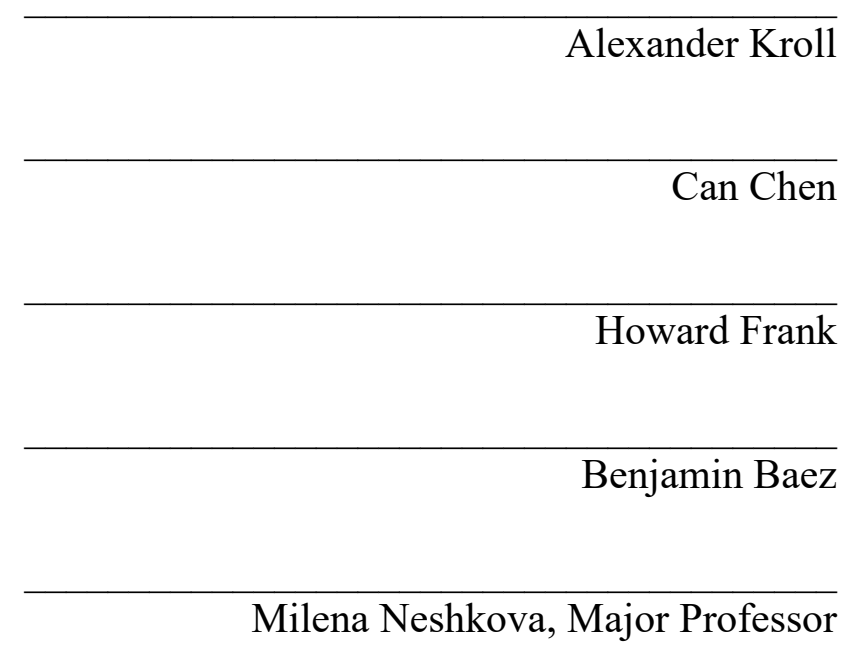

Date of Defense: March 25, 2020

The dissertation of Lilia Silverio-Minaya is approved.

Dean John F. Stack, Jr. Steven J. Green School of International and Public Affairs

Andrés G. Gil Vice President for Research and Economic Development and Dean of the University Graduate School

Florida International University, 2020 
(C) Copyright 2020 by Lilia Silverio-Minaya

All rights reserved. 


\section{DEDICATION}

I dedicate this dissertation first and foremost to God, who allowed me the strength and perseverance not to give up and to keep pushing myself to be the best version of myself. To my husband, Jhonny, and our children, Fernando and Lia. Jhonny, thanks for all the support, for always being there since day one, and for encouraging me to keep going. I thank you, Fernando and Lia, for all the time I needed to be away taking courses, presenting at conferences, and for all the weekends we had to stay home so that I could stay on top of the deadlines and projects.

I also dedicate this dissertation to my mother, mi mami (Norma). From the bottom of my heart, this work is dedicated to you, for not giving up on me when I was a child, and for having had the vision to bring us to this wonderful country, which has allowed me to embark in this scholarly adventure. Tia Ylsa, your welcoming and unconditional support made this dissertation a reality, because whenever I was without options, you were there and still are.

Jhonny, I dedicate this to work to you and us because you have been the support I needed to have peace of mind, to know everything is taken care of, and to be able to focus my attention and time to write this dissertation.

Fernando and Lia, you are both my best work. The highlight of my life. I dedicate this dissertation to you and urge you to embark in the pursuit of your dreams. I want to earn a PhD because I know that, with it, I can show you that education enables you to discover the world, to reach the unimaginable.

*Note: the list is not exhaustive. 


\section{ACKNOWLEDGMENTS}

I would like to thank everyone who supported me throughout the past five years. I am grateful for the support of Florida International University. This institution has shaped my professional career and my research interests. The employee tuition waiver benefit, as well as the great benefit of professional development leave, allowed me to complete this PhD degree while being able to balance my full-time position. In addition, I would like to especially acknowledge my supervisor and friend, Dean Brian Schriner. I am appreciative of his support, flexibility, professional development guidance, and unconditional belief in me.

I would like to direct very warm appreciation toward my major professor, Dr. Milena Neshkova, who played a significant role in pushing me to think about this research topic from the first day I joined the program. One of my main take-aways from this program is being able to call Milena a friend and colleague. Special thanks to Dr. Alex Kroll, for entertaining my research and providing thoughtful feedback throughout this process. To all the committee members, for not hesitating to be part of this journey. A critical part of my support program is my "dream team," Ana and Evelyn. Thanks for sharing this ride with me and for providing me with interesting insights. You will be my two academic friends!

The encouragement of many individuals allowed me to reach this important milestone. I have many people to be grateful to: my brother and his wife, for looking after Fernando and Lia when I was away at conferences. My work family, Sunem and Rashida, who supported me throughout and were my cheerleaders.

*Note: the list is not exhaustive. 


\section{ABSTRACT OF THE DISSERTATION \\ ADOPTION, STRINGENCY AND IMPACT OF PERFORMANCE MANAGEMENT SYSTEMS: THE CASE OF U.S. PUBLIC HIGHER EDUCATION}

by

\section{Lilia Silverio-Minaya}

Florida International University, 2020

Miami, Florida

\section{Professor Milena Neshkova, Major Professor}

This dissertation contributes to a better understanding of performance management systems (PMS) by examining adoption, stringency, and impact of performance-based funding (PBF) in public institutions of higher education within the United States. The public sector has been under increasing pressure to be more accountable to stakeholders - that is, to perform better at lower cost. Yet, tracking the effectiveness of performance systems has been challenging, given the host of factors that affect results. Because of the growing use of performance systems, it is important to understand what factors affect the adoption and stringency of such systems, as well as their effectiveness.

Currently, 39 American states have adopted PBF models to hold public institutions of higher education accountable for reaching state-mandated goals. To assess the stringency of PBF models, the present study develops a novel measure: the Performance Funding Uncertainty Index (PFUI). This index consists of five components reflecting the major elements of PBF models adopted across the nation. Analyzing 15 years of panel data from research institutions of higher education in 39 states the study 
finds that adoption and stringency of the performance systems are not determined by the same factors. While PBF adoption is more likely in politically conservative states with underperforming education systems, it does not spread in a geographical pattern as diffusion theory predicts. Republican-led state legislatures tend to implement more stringent PBF models. Yet, PBF systems do not gradually become more stringent over time. Rather, the systems reach a saturation point and eventually stagnate. Using a difference-in-differences analysis, the study also finds that the PBF adoption and operation failed to deliver on its main goal - that is, to increase graduation rates of public universities. 


\section{TABLE OF CONTENTS}

CHAPTER

PAGE

CHAPTER 1 The Need for a Performance Management System: The Case of Higher Education . 1

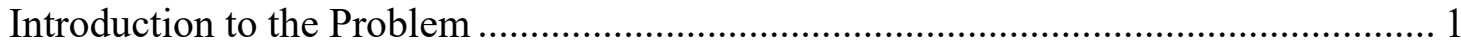

Performance Management Systems in the Public Sector ........................................... 4

Performance Management Systems in Higher Education ........................................... 5

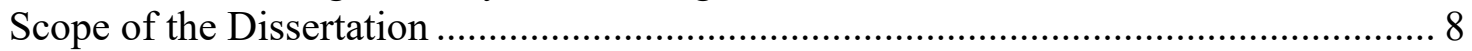

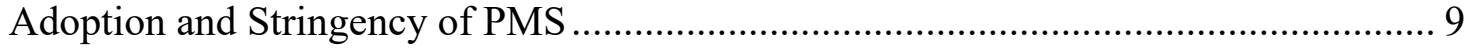

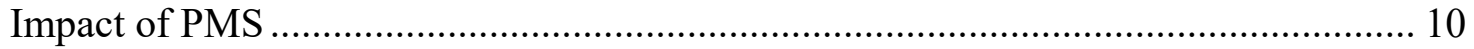

Significance of the Study .................................................................................. 12

CHAPTER 2 A Systematic Review of the Literature on Performance Management

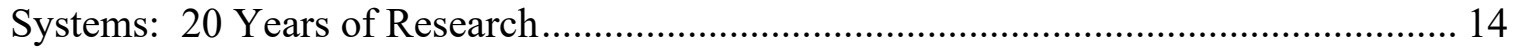

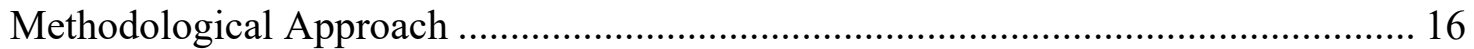

Literature Search..................................................................................... 16

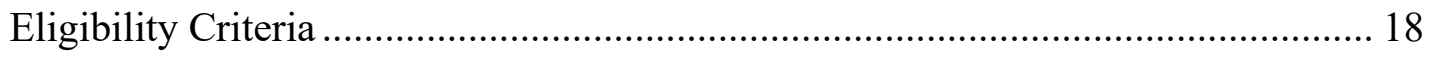

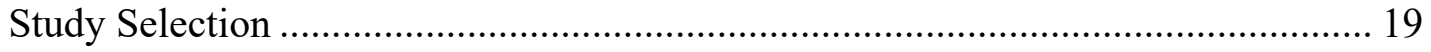

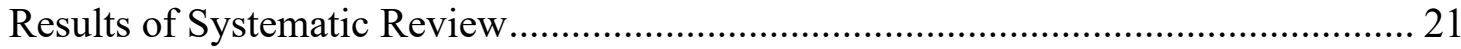

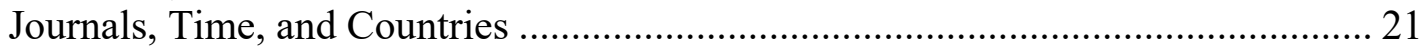

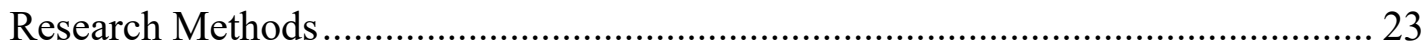

Public Sector Fields ................................................................................... 24

Analysis of Research Questions............................................................................. 24

Definitions of a Performance Management System ............................................. 24

Types of Performance Management Systems ....................................................... 26

Goals of Performance Management Systems ........................................................ 27

Themes in Performance Management Systems Research ...................................... 29

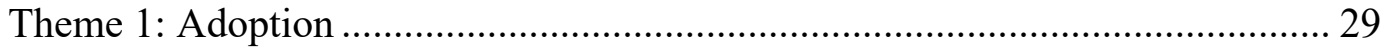

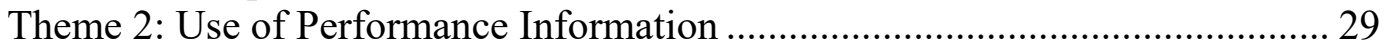

Theme 3: Impact of Performance Management Systems .................................. 30

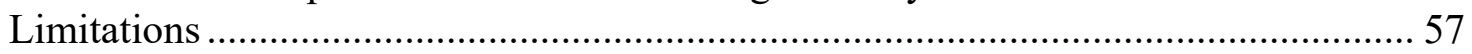

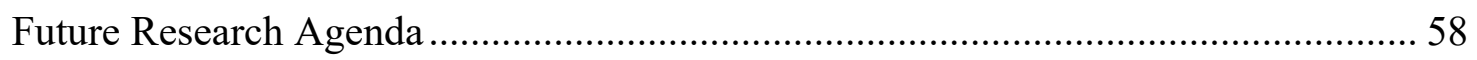

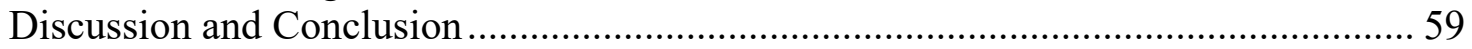

CHAPTER 3 A Theory of the Adoption and Stringency of Performance Systems: The

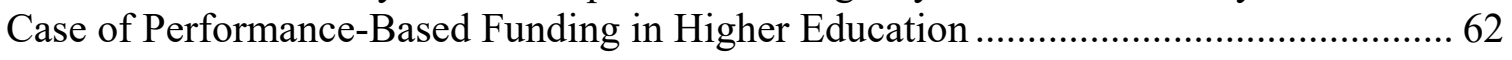

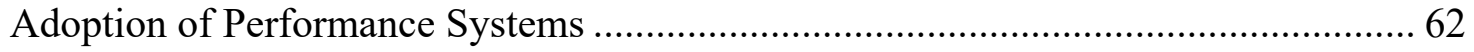

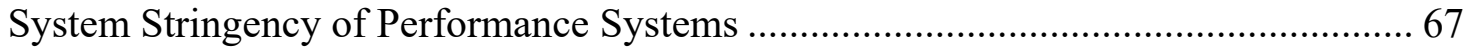

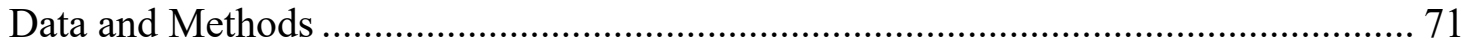

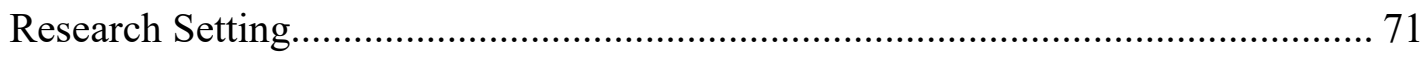

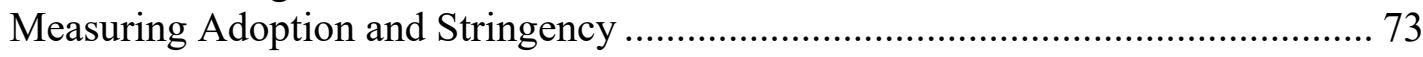

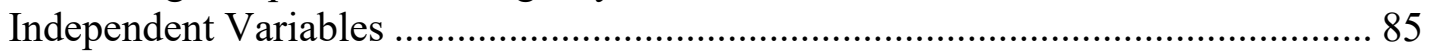

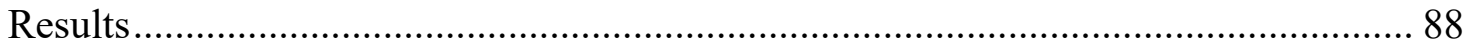




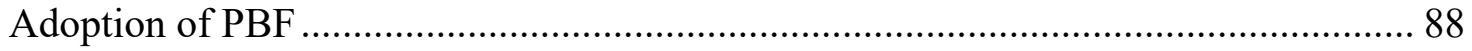

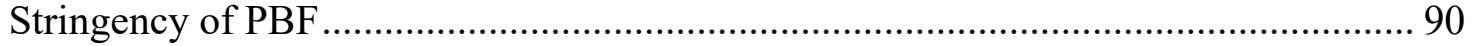

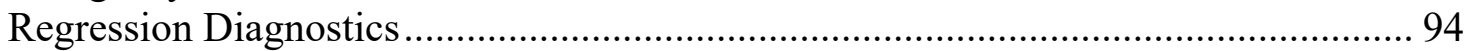

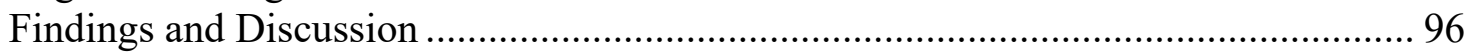

Limitations and Future Research ............................................................................ 99

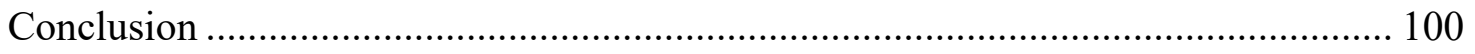

CHAPTER 4 The Impact of Performance-based Funding in Higher Education ............ 102

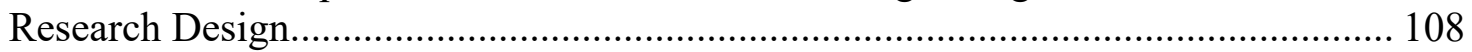

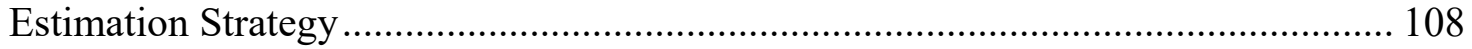

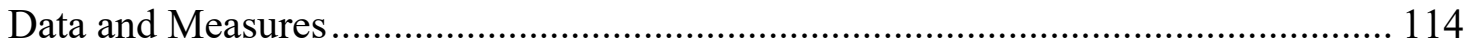

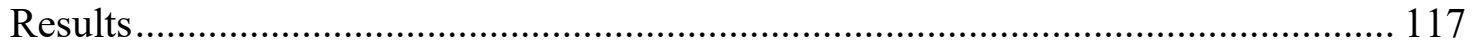

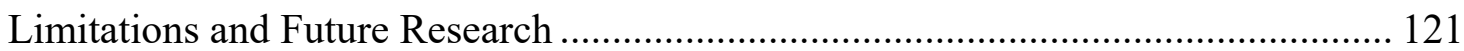

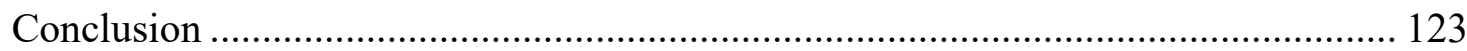

CHAPTER 5 Discussion, Implications, and Conclusions ............................................ 125

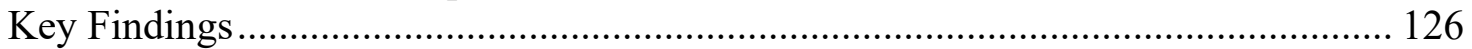

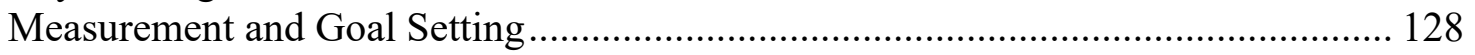

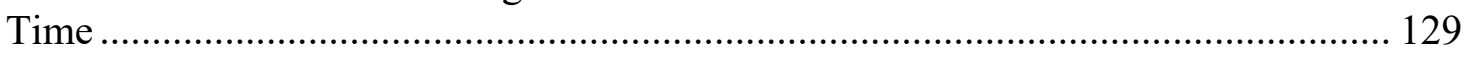

Are we willing to engage in the trade-off between PMS and values? ....................... 130

Implications for Public Policy Making and Management .......................................... 131

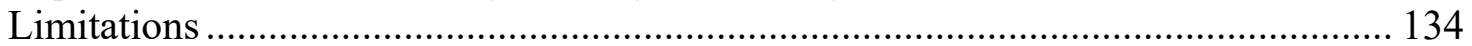

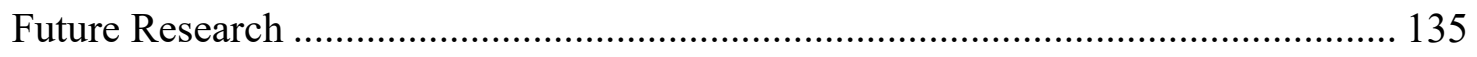

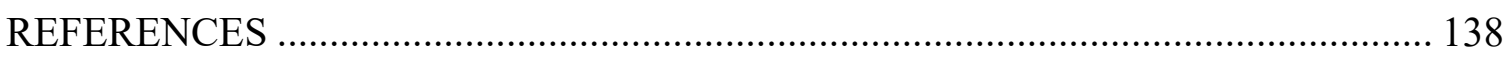

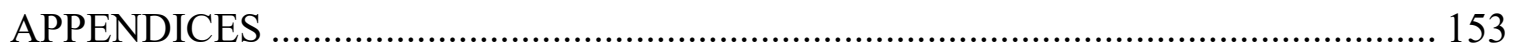

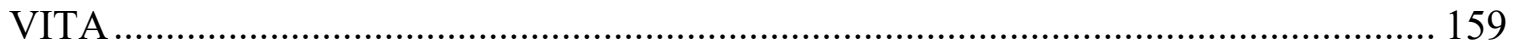




\section{LIST OF TABLES}

TABLE

PAGE

Table 1. Systematic Literature Review Search Summary ......................................... 17

Table 2. Performance Management System Track Record ….................................... 31

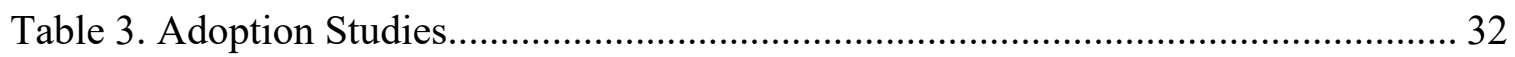

Table 4. Use of Performance Information Studies...................................................... 35

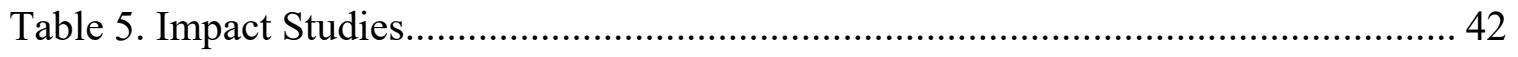

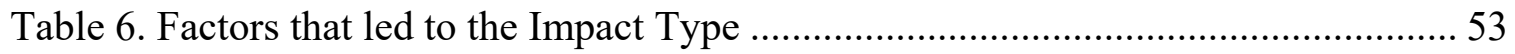

Table 7. PFUI: Performance-based funding Dimensions ............................................ 74

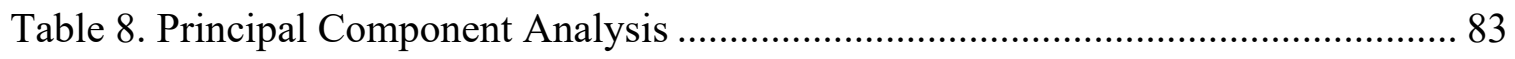

Table 9. Descriptive Statistics, Adoption and Stringency Models ................................ 87

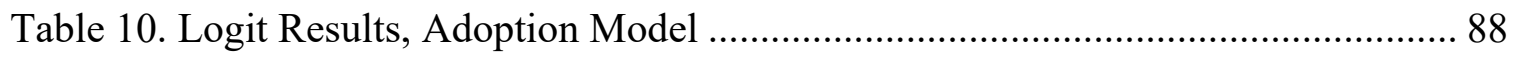

Table 11. Regression Results, Stringency Model ................................................... 91

Table 12. Descriptive Statistics, Impact Model ....................................................... 119

Table 13. Regression Results, Impact Model ......................................................... 120 


\section{LIST OF FIGURES}

FIGURE

PAGE

Figure 1. Performance Management Systems' Cycle and Overlaps ................................ 11

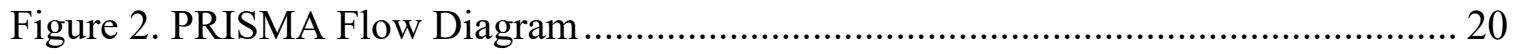

Figure 3. Performance Management Systems Research 2000-2019 _........................... 22

Figure 4. Performance Management Systems Goals ................................................ 28

Figure 5. States with PBF as of 2015 by Year of Adoption ....................................... 73

Figure 6. Predictive Margins: Anticipated trajectory of Stringency Level vs. Time........ 93

Figure 7. Parallel Trends Minority Enrollment....................................................... 113

Figure 8. Parallel Trends Graduation Rate within 150\% ..................................... 113

Figure 9. Parallel Trends Hispanic And African American Graduation Rate ................ 114 


\section{ABBREVIATIONS AND ACRONYMS}

ARRA

BLS

CSPIA

DID

GPRA

IPEDS

JTPA

KPI

NCSL

NPM

NASBO

OLS

PART

PBF

PFUI

PMS

PRISMA

SHEF
American Recovery and Reinvestment Act

Bureau of Labor Statistics

Child Support Performance and Incentive Act

Differences in differences analysis

Government Performance and Results Act

Integrated Postsecondary Education Data Systems

Job Training Partnership Act

Key Performance Indicator

National Conference of State Legislatures

New Public Management

National Association of State Budget Officers

Ordinary Least Squares

Program Assessment Rating Tool

Performance based funding

Performance Funding Uncertainty Index

Performance Management Systems

Preferred Reporting Items for Systematic Review and MetaAnalyses

State of Higher Education Finance 


\section{CHAPTER 1}

\section{The Need for a Performance Management System: The Case of Higher Education}

\section{Introduction to the Problem}

Soon after I began my PhD program, I became interested in performance fundingbased models. My interest stems from working at a public institution of higher education: Florida International University. After completing my Bachelor's degree in 2005, I worked as an accountant at my alma mater, which allowed me to witness, first-hand, how quickly the university's business activities changed as directed by our Provost, to stay laser on meeting the success metrics and goals that were established by the Florida Board of Governors. The better we performed, they said, the more funding the university would be entitled to receive.

What I witnessed was not unique to the State University System of Florida. In fact, many jobs within higher education were evolving at the beginning of the 2000's because of the need to adjust to a new funding environment. The new environment came as a result of increased scrutiny of institutions of higher education. Under the new environment, administrators were constantly reassessing priorities in order to remain aligned with the priorities of lawmakers. As I became immersed in the field of public administration through my core doctoral coursework, I soon realized that the increasing focus on PBF in public higher education was a phenomenon that also impacted the overall public sector.

Public American institutions of higher education are experiencing fundamental changes to their funding mechanisms. The initial design of these mechanisms did not 
produce significant results in terms of increasing educational attainment. These structures were initially known for highlighting inputs—-that is, the number of enrolled students. The initial funding mechanisms were enrollment-based funding models. The more students the institutions enrolled, the more funding they received. The problem with this formula is that while students were admitted, controls were not installed to ensure that universities fulfilled their obligations to graduate and retain students. Under this model, public higher education institutions did not have a system of checks and balances. They received funds based on the number of students they enrolled, but they were not held accountable for ensuring that those students completed their degree programs and graduated.

In my view, new funding models appeared in response to this dilemma. I was motivated to complete a dissertation on this topic so that I could support the model with literature, data, and analytics techniques. In this dissertation, I sought to investigate the factors that affect the adoption of a performance funding system and the configuration of such as system. In addition, I sought to explore its impact. That is, are these funding models able to positively impact students as the outputs and outcomes intended?

Several factors provoked the adoption of performance funding in higher education. The state's political climate is a factor at the top of the list. In the case of higher education, the political climate became increasingly hostile toward public universities and colleges (Rabovsky \& Rutherford, 2016). The hostility was not without reason - universities were not delivering results, particularly in reference to their inability to produce employable graduates. In addition, in the late 1990s, there was an increased demand to hold the schools accountable, coupled with calls for new funding models 
(Crow \& Shangraw, 2016; Rabovsky, 2014a). This was not an environment unique to public higher education, it was the common sentiment toward state services in general. This movement is in line with New Public Management (NPM) reforms. NPM is a school of thought that replaces traditional rules based-system with market-based, competitiondriven approaches where the citizens are considered customers of public services (Kettl, 2005).

Well-known organizations played an important role in the adoption of performance-based funding models in higher education. These included organizations such as the National College Completion Agenda, the Public Accountability Movement, the Bill \& Melinda Gates Foundation, and the Lumina Foundation, and Complete College (Li \& Kennedy, 2018). These factors resulted in a fiscal shift from an input-based model to an output-based model. The new funding models were initiated as a way to enhance accountability and transparency in higher education (Frølich, 2011). These funding models emphasize institutions' outputs and outcomes related to student performance. The rationale for the new funding mechanisms is that public universities qualify for state funding based on their success in student retention, graduation, and subsequent employment. These new funding mechanisms are commonly known as performancebased funding $(\mathrm{PBF})$.

For many reasons, higher education provides a great setting to examine this wave of changes. There are approximately 710 public four-year colleges or universities in the United States serving almost nine million students (U.S. Department of Education, 2018). Higher education budgets are roughly the third largest category in state budgets, preceded only by Medicaid and K-12 education, costing U.S. states a total of $\$ 78$ billion (Pew 
Research Center, 2019). Due to the increased emphasis on results that comes with PBF, institutions of higher education have been forced to adapt quickly. This dissertation significantly contributes to the literature on performance management systems by providing further evidence of the impacts generated by this policy instrument, which continues to be used throughout the United States.

\section{Performance Management Systems in the Public Sector}

The wide use of performance management systems (PMS) has a fundamental premise: organizational performance can be boosted by establishing performance goals, which can be achieved through effective management practice (Moynihan, 2006; Moynihan \& Pandey, 2005; Poister, 2003). Performance systems not only influence the behavior of public organizations by increasing their accountability (Meier \& O'Toole, 2006; Thomas, 2011; Rabovsky, 2014a), but also allow agencies to reassess the principles that drive their missions (Moynihan, 2005). Initial reforms in the American government were a result of efforts from the progressive movement to foster systematic scrutiny of government activities and operations (Melkers \& Willoughby, 2001). Reforms promised to raise awareness of performance among public managers (Moynihan \& Lavertu, 2012), who would have otherwise not have focused on this aspect.

Since 2010, performance management systems have been on the rise in most areas within the public sector. These systems were adopted for various reasons, including: to make informed choices and to better direct scarce resources (Bischoff \& Blaeschke, 2016; Sohn \& Bae, 2018; Vogel \& Hatke, 2018), to keep organizations accountable for efficient and effective performance (Favero \& Rutherford, 2019), and to enhance the quality of public services (Patrick \& Rollins, 2015; Walker, Damanpour \& 
Devece, 2011). Broadly, internal and external factors explain the adoption of performance systems. Political ideology and performance deficiencies are among the most common internal factors, with Republicans being more likely to institute policies that are indirectly skeptical of public bureaucracy than Democrats (McLendon, Hearn, \& Deaton, 2006). Other internal factors include generating cost savings, improving communications and program effectiveness, changing appropriation levels, decreasing duplicate services, and responding to citizen demands (Melkers \& Willoughby, 2001; Folz, Abdelrazek, \& Chung, 2009). Externally, the adoption of a performance system might be a perceived as a spillover resulting from adoption in another state.

\section{Performance Management Systems in Higher Education}

Performance-based funding (PBF) models are a type of performance management system (PMS). PBF emerged from the New Public Management (NPM) movement, which advocated the use of performance measures to allocate resources, to empower public employees to engage in continuous improvement of public programs, and to draw from the lessons on advantages of markets to produce greater efficiency in the public sector (Pollitt, 2000). NPM emphasizes efficiency, economies of scale, rationalization, development of greater market responsiveness, and increased private contributions in the case of public universities (Guthrie \& Neumann, 2007). Some of the practices associated with NPM implementation are auditing, constant reporting, performance funding, among others (Kettl, 2005).

Prior to PBF, there were different funding types, such as ones in which institutions received additional funds only, while in other cases the funding is reduced, or a combination of both. Although the idea of PBF in higher education is not new, only a 
few states utilized it prior to 2009. However, the number of states considering PBF models has been on the rise; since 2011, approximately 26 states have adopted—or are transitioning toward adopting-PBF models in higher education. As of 2015, 32 states had adopted. Of the 32 states, 65\% implemented the model from 2011 to 2016 (National Conference of State Legislatures, 2016). The underlying premise of the performancebased funding model is compelling: enhanced accountability. In other words, the overarching goal is to make universities more accountable to society by ensuring that they fulfill their commitments, particularly those relating to student graduation rates. PBF mechanisms are designed to directly tie institutional funding to benchmark indicators on student outcomes (Burke \& Henrick, 2003). The new state funding models focus on the institutions' outputs to determine the amount of funding an institution is entitled to receive. For certain institutions, the PBF is sometimes the only source of incremental funding from the state. Incremental funding are increases to an institution's base budget in excess of the prior year's base budget. In an era where budgets are tight and incremental funding opportunities are rare, PBF is critical for university administrators.

In the context of higher education, several factors have been identified as predictors of the PBF adoption. I classify these factors as mission-related, fiscal, local/state, and national. From a mission angle, there is a need to align university objectives with the states' goals and priorities (National Conference of State Legislatures, 2016) due to the overall state and federal government's lack of confidence in universities' performance (Ferlie, Musselin, \& Andresani, 2008). The fiscal aspect refers to the states' funding and the way in which universities manage their budgets in an environment where 
resources are scarce. For this reason, the declining state support for higher education is also an often-cited factor predicting PBF adoption (Birdsall, 2019).

At the state level, socioeconomic factors, state political-party composition, and legislative professionalism and regional diffusion (Birdsall, 2019) have been found to play a role in PBF policies. Local factors include ineffective teaching practices and substandard teachers without accountability (Birdsall, 2018). From a national perspective, the persistent decline in graduation rates at most community colleges, and the decline in retention rates from first to second year (McKinney \& Hagedorn, 2015), reflect poorly on United States programs. Notably, President Obama raised concerns about America's declining level of educational attainment (Hanes, 2017). Typically, PBF programs are adopted as a result of multiple factors occurring simultaneously.

The idea behind PBF is to produce quantifiable data that provide meaningful information about program outcomes (Melkers \& Willoughby, 2001). The implementation of PBF continues to expand. However, the operationalization of PBF often differs from its original conceptualization. In fact, the initial motivations to adopt PBF have faded over the years (Compagni \& Tediosi, 2012). While PBF was intended to increase accountability and transparency, it has become - in many cases - window dressing (Bischoff \& Blaeschke, 2016). In other words, the adoption of a PBF system is often only done for the symbolic benefits associated with its adoption.

Higher education is one of the many areas within the public sector that has experienced a shift in funding and performance evaluation. A much larger wave of reforms is currently occurring within different areas of government. The next section 
describes the movement of performance management systems from the broader lens of the entire public sector.

\section{Scope of the Dissertation}

This dissertation examines three interrelated research questions. The first question explores why some states adopt PBF for their public higher education systems, while others do not. The second question explores why some states opt for more stringent PBF models than others. The third research question seeks to investigate whether the advertised goals of PMS have been realized in the practice of PBF for public higher education. In summary, the current research will study three aspects of a PMS: adoption, stringency, and impact.

The dissertation utilizes a three-essay approach, where each essay serves a distinct purpose. The first essay (Chapter 2) provides a systematic review of prior research on performance management systems published in the last 20 years-from 2000 to 2019. The purpose of the literature review is to define the main terms related to performance management systems, to classify and define types of PMS identified in the literature, and to document the instances in which PMS have achieved outlined goals. The systematic literature review yielded a set of 185 paper published between 2000 and 2019. After removing duplicates and articles that did not meet the eligibility criteria, 59 articles were fully reviewed. I identified three dimensions that encompassed the definition of a performance management system. They are: goal setting, measurement, and performance information. Further, I find that the most prevalent type of performance management systems entails performance-based funding. Additionally, despite differences in how goals were articulated, the overall goal associated with the adoption of a performance 
management system is to enhance performance. The literature is mixed with regard to the effectiveness of PMS. A review of the literature provides support for the study of factors that affect adoption, as well as for studies that explore the impact of the PMS - topics that are covered in Chapters 3 and 4, respectively.

\section{Adoption and Stringency of PMS}

The second essay (Chapter 3) examines why some states adopt PFM for their higher education while others do not, and why some legislatures opt for very stringent models compared to others. Prior research has produced valuable insights linking the adoption of performance systems to factors such as performance pressure, ideology, and isomorphism. However, in Chapter 3, I argue that these are much less helpful in understanding different configurations of performance systems, or the stringency of the implemented systems. By and large, adoption is a result of pressure to "do something," and it is often used as a symbolic tool to show constituencies and the general public that an action was taken to address a problem that is salient and/or controversial. However, such pressure provides little direction on what system should be implemented in practice and how stringent it will be. In an attempt to address this gap in the literature, I developed an index that assesses the stringency of PBF: the Performance Funding Uncertainty Index (PFUI). The index consists of five dimensions reflecting the major features of the PBF models adopted across the states. The analysis shows that the stringency of performance systems is a function of learning over time through use. Systems may become more stringent at first (to address strategic behavior and performance lapses) but will eventually stagnate and rarely reach maximum stringency level. The theoretical framework to analyze these questions includes New Public Management, policy 
diffusion, and the principal agent. Ordinary Least Squares (OLS) regressions and Logit models were estimated using data from performance-based funding systems in higher education.

\section{Impact of PMS}

The third essay (Chapter 4) seeks to assess the impact of PBF models. The research literature on PMS effectiveness has produced mixed results (Gerrish, 2016; Kroll, 2017; Moynihan \& Pandey, 2006). Some scholars argue it works (Gerrish \& Spreen, 2017; Heinrich \& Marschke, 2010; Ho, 2011; Hong, 2018; Poister, Pasha, \& Edwards, 2013), while others argue that it does not (Adriano, 2014; Andersen, 2008; Angiola \& Bianchi, 2015; Gerrish, 2016; Vogel \& Hattke, 2018). There is too little research on actual impact of policies such as PBF. At best, the research on the effectiveness of performance management systems is inconclusive. Many studies report no results (Heinrich, 2002; Li \& Kennedy, 2018; Yang \& Kassekert, 2010); others find either positive or negative effects (Pasha, 2018; Walker, Damanpour, \& Devece, 2011; Wang \& Yeung, 2019).

This dissertation contributes to the body of research on the effects of performance-based policies by drawing on the example of public higher education and testing what effects, if any, the PBF funding models have produced. The hypotheses presented in Chapter 4 explore all three possibilities: no effect, positive effect, and negative effect. The analysis uses OLS regressions and the difference-in-differences technique.

The concluding Chapter 5 cross-analyzes all chapters by discussing all three studies with the objective of synthesizing the findings, providing recurring themes, and 
tracing an agenda for future research while acknowledging the study's limitations. Figure 1 below represents the overlap among key aspects of PMS addressed by different chapters of this dissertation. The findings of this study reveal that adoption, stringency, and impact are interrelated and share many commonalities - though each is unique in certain aspects. Among the relevant contributions from this dissertation are the issues found related to time, goal setting, incentives, and measurement.

Figure 1. Performance Management Systems' Cycle and Overlaps

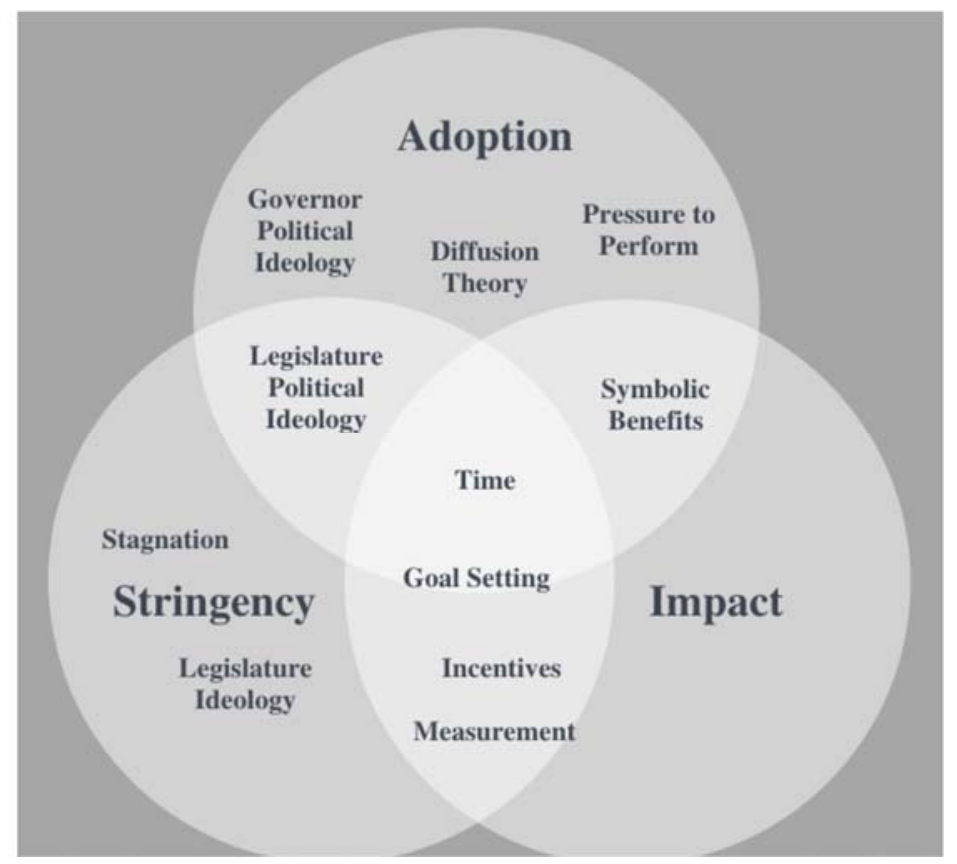

The dissertation utilized quantitative data to test the hypotheses. The empirical analysis was based on a panel data set which includes data from 2000 to 2015. Using panel data has several advantages over other data analytics tools, such as cross-sectional data. Hsiao (2007) outlined some of these advantages. Specifically, panel data usually allow for more degrees of freedom and more sample variability; panel data has greater capacity to capture the complexities associated with behavioral hypotheses; lastly, panel data allow for controlling the impact of omitted variables. 
The data were derived from various sources, including the Integrated PostSecondary Education Data System (IPEDS), National Conference of State Legislatures (NCSL), U.S. Census Bureau Data, and the U.S. Bureau of Labor Statistics, among others. The sample population consists of 4-year public, doctoral-degree granting institutions, with a designation of Carnegie Very High Research Universities, R1. I chose this group of universities as a way to control for the mission aspect. The mission of an institution of higher education is its reason for being, it defines its purpose and it represents the field of the organization (Ozdem, 2011). In the case of R1 universities, the assumption was that all institutions under this classification share significant commonalities (e.g., research expenditures, $\mathrm{PhD}$ degrees awarded). $\mathrm{R} 1$ institutions are striving institutions. O’Meara (2007) conceptualized striving as the "pursuit of prestige within the academic hierarchy" (p. 122). The total sample resulted in 82 universities. The university was the unit of analysis for the impact study; whereas the state was the unit of analysis for my examination of determinants of PBF adoption and stringency.

\section{Significance of the Study}

This dissertation contributes to the body of literature in multiple ways. First, it challenges current knowledge on PBF, which equates the factors explaining adoption and stringency of performance systems. I argue that these are two separate processes that are only loosely connected. Second, I provide a new theoretical explanation of how adopted performance systems evolve over time. Third, I develop a new measure to assess the stringency of performance systems in higher education. To produce the index, the features of performance-based funding systems in all 39 states were explored over time. The Performance Funding Uncertainty Index (PFUI) consists of five dimensions. The 
PFUI contributes to the research literature by allowing comparison of PBF models and how they are configured. Understanding the factors that affect the adoption and stringency of performance systems has clear implications for the theory and practice of public management.

This dissertation contributes to the research literature by providing further evidence of the impacts generated by $\mathrm{PBF}$ - a policy instrument that continues to be used across the United States. Currently, 39 states and 210 four-year state universities have employed performance-based funding (National Conference of State Legislatures, 2016). The trend has been part of the broader performance management movement in public administration and its effectiveness in practice, as well as the unintended consequences from its use, which are still too early in the process to be fully understood. This study is relevant to three identifiable stakeholders:

- State legislators and policymakers are concerned about universities' return on investment because of the millions of dollars allocated annually to higher education institutions via state appropriations and federal government and agencies. This dissertation will help state legislators by providing insight into the success of accountability mechanisms. Higher education is the third largest category for states' spending, reaching $\$ 78$ billion combined in 2013 (Pew Charitable Trusts, 2019). While higher education is a small portion of the federal budget, it still represents a significant dollar amount: $\$ 3.98$ trillion for the fiscal year 2017 (Pew Charitable Trusts, 2019). 
- The study is relevant to university administrators because it will allow them to learn from the impact of this policy tool. This, in turn, will help them to manage implementation of performance-based funding models at their own institutions.

- Public universities provide opportunities to the overall society, especially for individuals from lower socio-economic backgrounds.

The study contributes to the research literature on the applications of performance management systems in the public sector—specifically in public institutions of higher education.

\section{CHAPTER 2}

\section{A Systematic Review of the Literature on Performance Management Systems: 20 Years of Research}

This chapter offers a systematic review of the literature on performance management systems (PMS) published between 2000 and 2019. The research sought to accomplish several objectives. The first objective was to identify research themes in the PMS literature. My second objective was to provide a definition of PMS, common types of PMS and their goals, and a review of the literature on the factors that led to adoption of PMS. Lastly, a review of the literature covering the effectiveness of PMS is included. The third objective was to set an agenda for future research. The insights stemming from this review will aid with the identification of potential gaps in the literature and will, therefore, provide direction in the establishment of a robust research agenda.

This analysis was guided by the following research questions: 
1. What definitions of performance management systems are identified in the literature?

2. What specific types of performance management systems are identified in the literature?

3. What goals have been attributed to a performance management system?

4. What are the impacts of various performance management systems as identified by the literature?

5. What limitations are found by the studies analyzed?

6. What avenues of future research are proposed in the literature?

In developing the systematic literature review, I adhered to the widely used Preferred Reporting Items for Systematic Review and Meta-Analyses (PRISMA). The systematic literature review yielded a set of 185 papers published between 2000 and 2019. After removing duplicates and articles that did not meet eligibility criteria, 59 articles were fully reviewed. I identified three key dimensions of a performance management system: setting, measurement, and performance information. Further, I found that the most prevalent type of performance management system is performance-based funding. Additionally, despite differences in how goals were articulated, the overall goal associated with the adoption of a performance management system was to enhance performance. Regarding the effectiveness of PMS, the literature was mixed. This review of the literature provides directions for future research, as well as limitations of current studies.

The chapter proceeds as follows. First, an overview of the methodological approach is presented. Then, the results of the systematic review are provided. This is followed by an 
analysis of the research questions. Finally, the conclusions and future research implications are provided.

\section{Methodological Approach}

\section{Literature Search}

Cooper (2010) identified four strategies to conduct a systematic literature review. The objective of this review was to provide a thorough analysis of the current state of the literature and an overview of the evolution of studies in this area. For this reason, I selected the period from 2000 to 2019, a 20-year period. An illustration of the number of articles resulting from each keyword search is included in Table 1. Two of Cooper's four strategies were used in this review. First, I conducted a search using Google Scholar. The keywords used were "performance management system," "performance management system adoption," "performance management system effects," "performance management system outcomes" in "public administration." This search, which generated 152 results, was performed on August $31^{\text {st }}$, 2019. Another term often utilized and perceived as a synonym of performance management is "management for results." For this reason, an additional search was performed using the keywords "management for results," "management for results adoption," "management for results impact," "management for results effects," and "management for results outcomes" in "public administration." The selection of these terms was done in consultation with members of the search and screen committee and my major professor. This search generated 20 results and was conducted on September $1^{\text {st }}, 2019$.

Finally, a search was done using the keywords "performance-based funding," "performance-based funding adoption," "performance-based funding impact," 
"performance-based funding effects," and "performance-based funding outcomes" in "public administration." This search generated 76 results and was done on September $1^{\text {st }}$, 2019. The term public administration was used to exclude literature results related to the private sector.

Table 1. Systematic Literature Review Search Summary

\begin{tabular}{|l|c|c|c|c|}
\hline \multicolumn{1}{|c|}{ Keyword } & $\begin{array}{c}\text { Performance } \\
\text { Management } \\
\text { System }\end{array}$ & $\begin{array}{c}\text { Management } \\
\text { for Results }\end{array}$ & $\begin{array}{c}\text { Performance } \\
\text { Based Funding }\end{array}$ & TOTAL \\
\hline $\begin{array}{l}\text { American Review of Public } \\
\text { Administration }\end{array}$ & 0 & 1 & 1 & 2 \\
\hline Google Scholar & 152 & 20 & 76 & 248 \\
\hline JSTOR & 463 & 5 & 870 & 1338 \\
\hline $\begin{array}{l}\text { Journal of Policy Analysis } \\
\text { and Management }\end{array}$ & 16 & 8 & 3 & 27 \\
\hline $\begin{array}{l}\text { Journal of Public } \\
\text { Administration, Research } \\
\text { and Theory }\end{array}$ & 18 & 24 & 2 & 44 \\
\hline Public Administration & 20 & 20 & 7 & 47 \\
\hline $\begin{array}{l}\text { Public Administration } \\
\text { Review }\end{array}$ & 35 & 29 & 8 & 72 \\
\hline Public Management Review & 19 & 18 & 6 & 43 \\
\hline TOTAL & $\mathbf{7 2 3}$ & $\mathbf{1 2 5}$ & $\mathbf{9 7 3}$ & $\mathbf{1 8 2 1}$ \\
\hline \hline
\end{tabular}

As a second strategy, I searched for journal articles on performance management in journals in Public Administration using JSTOR. These journals included Public Administration Review, Public Administration Quarterly, Journal of Policy Analysis and Management, Journal of Public Administration, Research and Theory, and Public Performance and Management Review. The same key words that I used in Google Scholar were used here, and a total of 1,338 journals were identified. The searches were performed on August 31, 2019. JSTOR journal publication dates were not up-to date: Public Administration Review was only available through 2013; Public Administration 
Quarterly through 2016; Journal of Policy Analysis and Management through 2013; Journal of Public Administration, Research and Theory through 2013; and, Public Performance and Management Review through 2011. To account for publications not included in JSTOR, an additional search was conducted using the Florida International University Green Library search engine in these journals. The search in Public Administration Review generated 72 results; the Journal of Policy Analysis and Management generated 27 results; the Journal of Public Administration Research and Theory resulted in 44 articles. Three additional journals were included in this search because they were not available through the library search engine. They are: Public Management Review, American Review of Public Administration, and Public Administration. The search in Public Management Review yielded 43 articles, while the search in American Review of Public Administration generated 2 results. The search in Public Administration produced 47 results.

\section{Eligibility Criteria}

I adhered to the widely used Preferred Reporting Items for Systematic Review and Meta-Analyses (PRISMA). Studies from my original searches were only included in the systematic review if they met all of the following inclusion criteria:

- Field: Studies must be in the field of performance management in the public sector.

- Topic: The following keywords must be included in the title or abstract of the article: "management for results," "performance-based funding," "performance management system," "performance management," "performance funding," 
"performance-based budgeting," "performance system," or "performance budgeting."

- Study design: Only empirical, quantitative studies were included in this analysis because I was interested in rendering a comprehensive accounting of how performance management was understood using quantitative analytical tools.

- Publication year: Studies that were published between 2000 and 2019 were included. This covered a 20 -year period, which would allow me to develop a full understanding of advancements in the literature on performance management, as well as develop avenues for future research.

- Language: Only records written in English were included.

- Publication status: Studies must have been conducted by at least one researcher at the $\mathrm{PhD}$ student-level. Studies were only included when they had a reference to the place of dissemination (journal, academic conference).

\section{Study Selection}

In total, I screened approximately 2,000 articles. Based on the eligibility criteria, I eventually included 59 articles. My selection process is depicted in Figure 2. 
Figure 2. PRISMA Flow Diagram

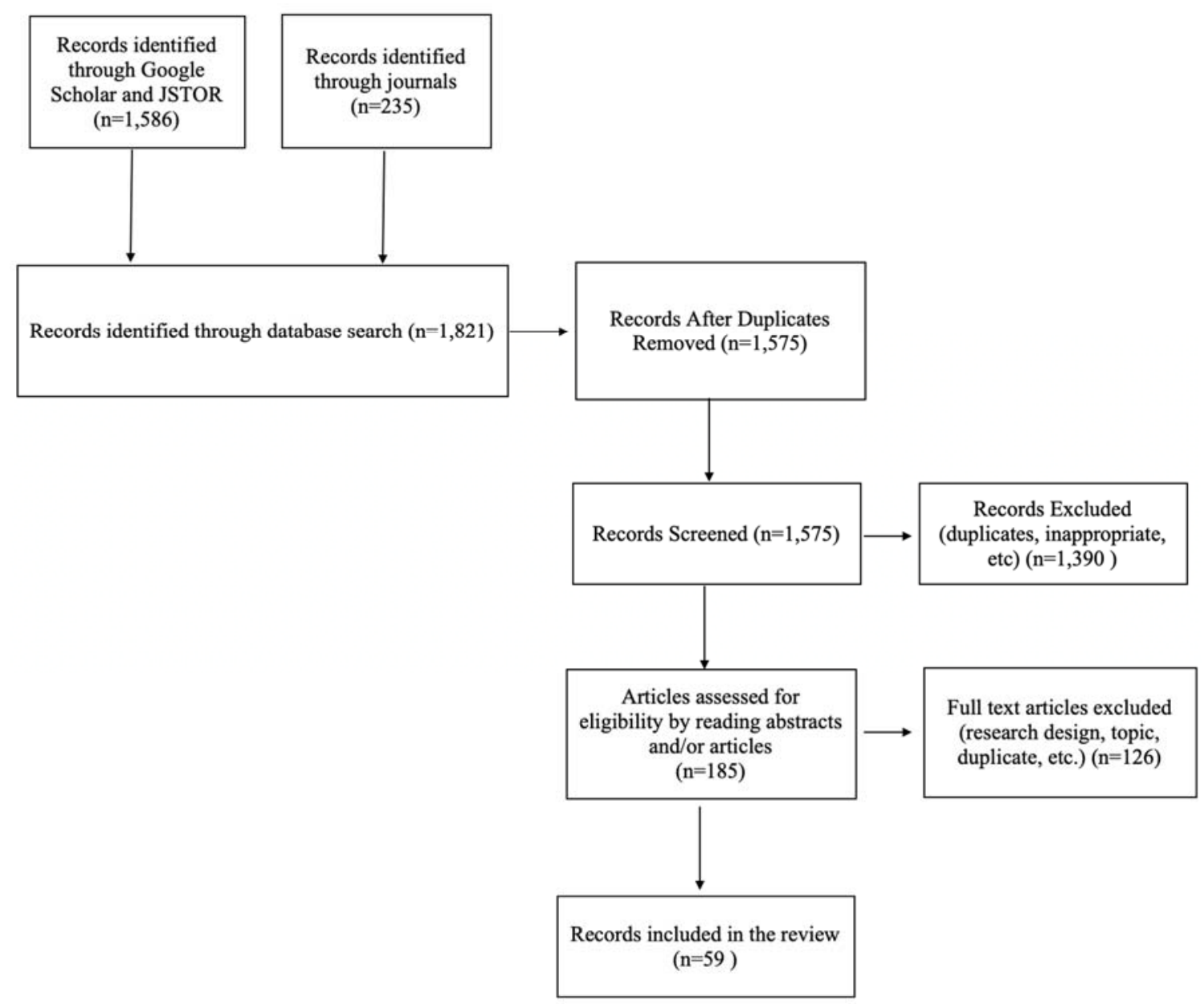

First, I screened the studies by scanning the abstracts and titles. For this purpose, I checked the articles against the eligibility criteria as previously outlined (topic, language, year, etc.) to determine if they would be included in the review. For example, a selection criterion was the inclusion of "performance management" in the title. Articles were not selected if the title included only "performance." This allowed me to eliminate many articles in other disciplines (e.g., Human Resources). The field was another important selection criterion. Articles were excluded if they were not specific to the field of public administration. This first step also allowed for the exclusion of articles that were duplicates. 
In the second step, articles were screened by reading the full text. Here, I excluded studies primarily because they used qualitative techniques (e.g. Bianchi \& Tomaselli, 2015; Cosenz, 2018) or because they were not relevant to the topic (e.g., Eremin, Wolf, \& Woodard, 2010; Lavertu \& Moynihan, 2012b). This was a timeintensive process as the relevance to the study was not always obvious from the abstract and required reading the complete article to fully understand its scope.

For each study selected, I developed a data extraction form to summarize the author, publication year, title, journal, volume and issue, methods used, objective of the study, definitions used, antecedents of the performance management system, type of performance management, theoretical framework utilized for the study, goals of the performance management system, area of government, population and main variables, as well as the study conclusion, limitations, and avenues for future research. I then categorized each study based on scope-specifically, whether the study investigated: the impact of a performance management system, the adoption of PMS, or the use of performance information. Further, if the studies focused on the impact of a PMS, themes were created in order to group the material into four categories. The first category demonstrated that a PMS produced mixed results, the second determined whether it had positive effects, the third negative effects, and the fourth no effects.

\section{Results of Systematic Review}

\section{Journals, Time, and Countries}

The 59 articles included in the systematic review were published in 15 different journals. More than half were published in two: Public Administration Review (17) and the Journal of Public Administration Research and Theory (16). The third journal with 
the most publications was the Public Performance Management Review (6). The majority of journals were specific to the Public Administration field. It is worth noting, however, that 3 journals were specific to education policy: Community College Review, Educational Evaluation and Policy Analysis, and Research in Higher Education. One publication appeared in a more general journal that focuses on social sciences in particular: American Behavioral Scientist. While most papers were published in peerreviewed journals, some were PhD dissertations (2) or books chapters (2).

The vast majority of papers were published in the last 10 years (72\%), during the period of 2011-2019. From 2000-2010, only 17 papers were published, and only 5 papers were published during 2000-2005. (See Figure 3.)

Figure 3. Performance Management Systems Research 2000-2019

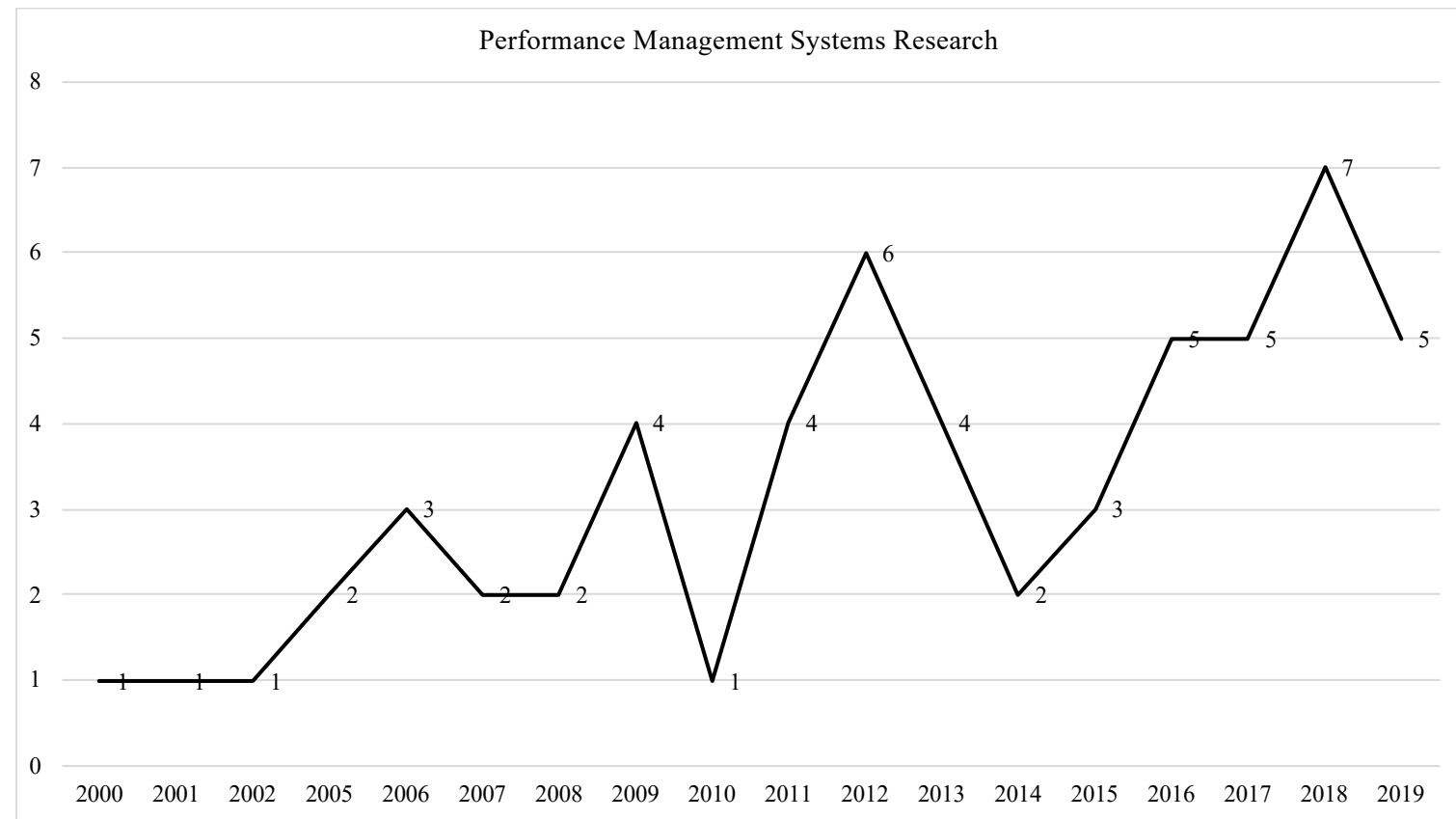

While this literature review focuses on publication years between 2000 and 2019, some of the articles examined performance management systems during periods prior to the year 2000 (e.g., Heinrich, 2000; Melkers, 2006). The period most frequently studied 
was during the first five years of the decade, from 2000-2005 (29\%). There were 10 articles (17\%) that examined the period 2006-2010, and 10 articles that examined performance management systems during the period between 2011 and 2015. Only one article investigated the period between 2015 and 2019. Lastly, 9 articles covered more than 10 years in their study (e.g., Hillman, Tandberg, \& Fryar, 2015; Gerrish, 2017; Birdsall, 2018).

Many of the included studies were conducted in the context of the United States (76\%). Other studies focused on Italy (7\%), Denmark (5\%), England (3\%), and Korea (3\%). The remaining articles each focused on other countries [e.g., China (1), New Zealand (1), and Taiwan (1)].

Donald Moynihan was the most frequently cited author in the articles. This researcher was either solo author or co-author in seven of the articles included in this review. Ed Gerrish, with three articles, was the next author whose work was most cited as part of this review. Other authors worth mentioning — because they participated in more than one of the articles included in this review—were: Birdsall, Gilmour and Lewis, Heinrich, Hillman, Kroll, Melkers, Lavertu, Pasha, Poister, Rabovsky, Willoughby, and Yang.

\section{Research Methods}

As specified in the selection criteria, all of the included studies used quantitative techniques. The majority of analytical methods were either difference-in-differences (7), ordinary least squares (OLS) multiple regression (13), panel interrupted time series using regression analysis (3), and PROBIT (4). Some articles used more advanced techniques, 
such as Montecarlo simulation (Favero \& Rutherford, 2019), multilevel structure (Holm, 2018; Heinrich, 2002), and structural equation modeling (Yang \& Hsieh, 2007).

\section{Public Sector Fields}

Due to the increased emphasis on PMS adoption across the public sector, it was important to identify the industry field within the public sector that was the basis for each article. The federal government was the study area within government that was most prevalent ( $36 \%$ of reviewed articles). This was followed by education (31\%). I subdivided studies focusing on education into K-12 (12\%) and higher education (19\%) because they significantly differ. Local government (19\%) has also been explored. A small portion of the articles focused on health (5\%). Other areas of government studied included police and transit, among others.

\section{Analysis of Research Questions}

\section{Definitions of a Performance Management System}

In this section, I aimed to consolidate the definitions of a performance management system. Moynihan (2008) defined a performance management system as one that produces performance information via strategic planning and performance measurement processes. This information was associated with decision venues - where, ideally, the information impacts a variety of potential decisions. Moynihan's definition has been used by several authors included in this review (e.g., Gerrish, 2016; Gerrish, 2017; Pasha, 2018). This was not the only definition, however. To that end, I have classified the definitions into three dimensions:

1. Goal setting (e.g., Andersen, 2008; Dimitrijevska-Markoski \& French, 2013; Kroll, 2017; Poister et al., 2013): In order for a performance management system 
to exist, clear goals must be established. A certain level of performance must be targeted as desirable to achieve.

2. Measurement (e.g., Barnow, 2000; Bourdeaux \& Chikoto, 2008; DimitrijevskaMarkoski \& French, 2019; Gerrish \& Spreen, 2017; Lam \& Wang, 2014): The goals must be measured to track improvement (Kroll, 2017). The measurement of performance helps focus on the achievement of the goals (Poister, 2003).

3. Performance information (e.g., Angiola \& Bianchi, 2015; Birdsall, 2018; Rabovsky, 2014a; Gerrish, 2017): This is a predominant theme in the literature on performance management systems. Thirty-four (43\%) of the included papers focused on the use of performance information (e.g., Bourdeaux \& Chikoto, 2008; Follz et al., 2009; Moynihan, 2006; Moynihan \& Lavertu, 2012). The use of performance information is considered the fundamental objective of a performance management system (Lavertu \& Moynihan, 2012b). The most obvious definition of performance information use is the analysis of information acquired through a performance management system (Ammons, 2001; Van Dooren, Bouckaert, \& Halligan, 2010). A much more novel definition, though, was suggested by Moynihan and Pandey (2010), who defined performance information as "a form of organizational behavior. Like other forms of organizational behavior, employees have discretion about whether, and the degree to which they engage in it, but are influenced by the social context and formal systems in which they work" (p. 852).

Therefore, a performance management system is a policy innovation tool that requires the establishment of goals and the subsequent tracking and measurement of progress 
made toward reaching those goals. The information generated through the tracking of the progress toward goals is called performance information. A performance management system requires the establishment of goals, and their tracking. The use of tracking information may determine whether or not the goals have been fulfilled. The present research revealed that, typically, a PMS is adopted at an institution without regard to its effectiveness or usefulness.

\section{Types of Performance Management Systems}

The way in which different sectors have operationalized the concept of a performance management system varies significantly. Annual performance reports, annual steering documents, company contracts, and measurement of workload and output are examples of the more traditional systems. Other systems are more sophisticated, such as the federal government Program Assessment Rating Tool (PART). Six studies on PART were included in this dissertation (Moynihan \& Kroll, 2017; Moynihan \& Lavertu, 2012; Lavertu \& Moynihan, 2012a; Moynihan, Lavertu, \& Kanensky, 2012; Moynihan, 2006). Other similar programs, which have become emblematic of the American government, are the Child Support Performance and Incentive Act (CSPIA) (Gerrish, 2017), the Job Training Partnership Act (JTPA) (Heinrich, 2002), the U.S. No Child Left Behind Act (e.g. Heinrich, 2009), and the Government Performance and Results Act (GPRA) (e.g., Moynihan \& Lavertu, 2012). All of these programs seek to reform the federal government by standardizing performance information, which will in turn lead to better decision making (Moynihan, 2006).

Performance management systems have become a primary tool to establish state appropriations and overall agency budgets. The type of performance system that was 
most often found in the reviewed articles was the performance-based-funding system (as described by Lu, Willoughby, \& Arnett, 2009; Hanes, 2017). In the context of higher education, Heinrich (2017) defined performance-based funding as a pre-determined formula to connect institutional funding to performance measures. Lu et al. (2009) defined it broadly as a "code that stipulates measurement of government performance and the application of such measurement to the budgeting” (p. 270). Performance-based funding management systems have been considered to be among the strongest accountability policies (Burke, 2002) because institutional funding is directly connected to the attainment of performance indicators.

\section{Goals of Performance Management Systems}

As previously explained, goal setting is an important dimension of a performance management system. The overarching goal of any PMS, notwithstanding any other factors which may affect policy-decision, is to enhance performance. However, these goals may be articulated differently—depending on the organization's field. Figure 4 presents a word-cloud that is based on the goals articulated in the papers in this systematic review. Managers and management are central to the performance management system. Some of the most common themes include: improve, performance, incentives, achieving, improving, decision making, goals, and results. 
Figure 4. Performance Management Systems Goals

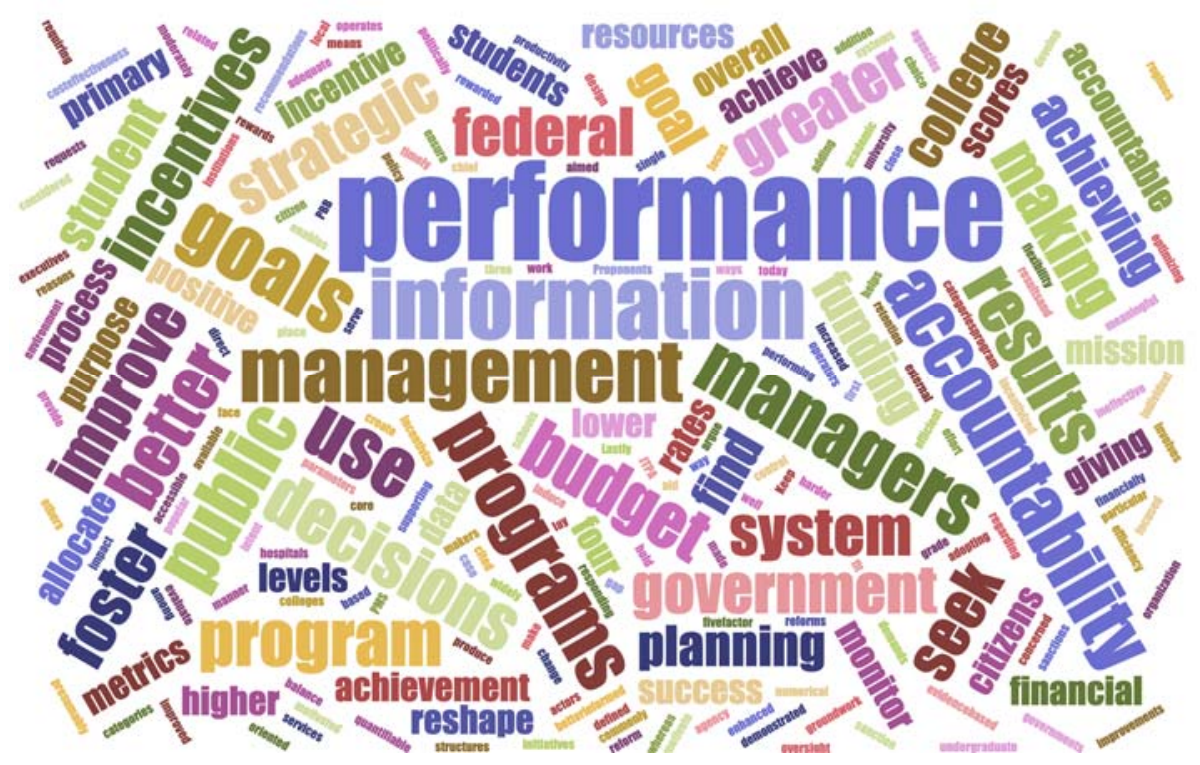

I analyzed the goals based on the area of government where the performance management system was utilized. In the case of the federal government, the goals of the performance management system seek to monitor lower levels of government to develop scores for management categories, to allocate budget resources, to determine strengths and weaknesses of federal programs, and to foster performance information in decision making (Barnow, 2000; Gilmour \& Lewis, 2005; Lavertu \& Moynihan, 2012b; Moynihan, 2006; Moynihan \& Lavertu, 2012; Sohn \& Bae, 2018). For higher education, the goals of the PMS are to increase accountability, find better ways to enhance student success metrics, and to re-shape incentives (Hillman et al., 2015; Hanes, 2017; Rabovsky, 2012; McKinney \& Hagedorn, 2015; Li \& Kennedy, 2018). Lastly, for performance management systems in local governments, the goals can be described as a way to increase accountability, foster the use of performance information, and to enhance customer satisfaction (Dimitrijevska-Markoski \& French, 2019; Folz et al., 2009; Gerrish \& Spreen, 2017; Marvel \& Marvel, 2007). 


\section{Themes in Performance Management Systems Research}

Studies were coded based on authors' objective - as outlined in the abstract and/or introduction of each article. For this, I created three categories. The first group includes studies that focus on the adoption of a performance management system. The second set focuses on the use of performance information. The third group focuses on the impact of the performance. A total of 15 studies were categorized in group 1; 34 articles analyzed the use of performance information in the second group; 23 articles studied impact, in group 3. Some studies were coded under more than one category (e.g., Folz et al., 2009; Lam \& Wang, 2014).

\section{Theme 1: Adoption}

In 2001, it was reported that the adoption of PMS was progressing slowly (Melkers \& Willoughby, 2001). By 2009, performance management systems were more widespread than ever (Folz et al., 2009). Governing structures, legislatures, partisan preferences, management, external actors, and organizations' current performance were central forecasters of the adoption of a PMS (Birdsall, 2019; Bourdeaux \& Chikoto, 2008; Hvidman \& Andersen, 2013; Rabosky, 2014; Yang \& Hsieh, 2007). Table 3 presents the complete list of articles that were categorized into this theme.

\section{Theme 2: Use of Performance Information}

I discussed the use of performance information above (see Definitions of a Performance Management System section). See Table 4 for a list of complete studies under this theme. The literature reveals that the utilization of performance information is high (Folz et al., 2009; Gill, Kengmama, \& Laking, 2012). Some studies also find the opposite (e.g., Angiola \& Bianchi, 2015). The presence of a PMS alone does not yield 
enhanced performance. It is critical that the information generated by the PMS be used for the PMS to be successful (Gerrish, 2016).

\section{Theme 3: Impact of Performance Management Systems}

Twenty-three of the 59 articles included in this review studied the impact of the performance management system. Table 5 summarizes the findings and provides information on the articles. These articles examined whether or not the PMS resulted in enhanced performance. In general, the studies examined the relationship between the use of public management reforms and performance (Andersen, 2008), the implications of performance funding (Birdsall, 2018; Favero \& Rutherford, 2019), and the overall impact

of a PMS (e.g., Gerrish, 2016; Gerrish, 2017; Gilmour \& Lewis, 2005; Hall \& Handley, 2011).

Studies were coded based on their conclusions: mixed results, positive results, unintended consequences, or no effects. Some studies were coded under more than one category (e.g., Andersen, 2008; Birdsall, 2018). Table 2 illustrates the proportion of studies that were classified under each coding category. Sixty-two percent of the studies were coded as having mixed results, unintended consequences, or no effects. There is ample evidence of studies reporting unintended consequences or warning about the possibility of the existence of unplanned outcomes. Papers were classified as mixed results if some variables within the study improved, while other variables within that study did not change or deteriorated. Mixed results studies represent $23 \%$ of the selected papers. The percentage of studies that did not report positive results was unexpected, given the significant effort and resources that were directed toward PMS adoption. 
Table 2. Performance Management System Track Record

\begin{tabular}{|l|c|c|c|c|}
\hline Impact Studies & $\begin{array}{c}\text { Mixed } \\
\text { Results }\end{array}$ & Positive & Unintended & No Effects \\
\hline Percentage of Total & $23 \%$ & $38 \%$ & $19 \%$ & $19 \%$ \\
\hline
\end{tabular}


Table 3. Adoption Studies

\begin{tabular}{|l|l|l|l|}
\hline Author(s) & $\begin{array}{l}\text { Publication } \\
\text { Year }\end{array}$ & \multicolumn{1}{|c|}{ Title } & \multicolumn{1}{c|}{ Conclusion } \\
\hline 1. Birdsall & 2019 & $\begin{array}{l}\text { Policy Adoption, Innovation, and } \\
\text { Performance Management: The Case of } \\
\text { Performance Funding Policies in State } \\
\text { Postsecondary Education }\end{array}$ & $\begin{array}{l}\text { State higher education governing structures, } \\
\text { increases in public tuition, and educational } \\
\text { attainment are important predictors of adoption. }\end{array}$ \\
$\begin{array}{l}\text { 2. Compagni } \\
\text { and Tediosi }\end{array}$ & 2012 & $\begin{array}{l}\text { Implementing Performance-Based } \\
\text { Funding for Health Research: When } \\
\text { Governance and Procedural Fairness } \\
\text { Matter }\end{array}$ & $\begin{array}{l}\text { Implementation of performance-based funding } \\
\text { has persisted, but it has been implemented } \\
\text { differently from what had been imagined. }\end{array}$ \\
\hline $\begin{array}{l}\text { Follz, } \\
\text { and Chung }\end{array}$ & 2009 & $\begin{array}{l}\text { The Adoption, Use, and Impacts of } \\
\text { Performance Measures in Medium-Size } \\
\text { Cities: Progress Toward Performance } \\
\text { Management }\end{array}$ & $\begin{array}{l}\text { Improving the decisions made by managers, } \\
\text { supporting budget recommendations and } \\
\text { decisions, and responding to citizen demands for } \\
\text { greater accountability are the three reasons most } \\
\text { commonly cited by chief executives for adopting } \\
\text { performance measures in the first place. }\end{array}$ \\
\hline $\begin{array}{l}\text { 4. Gilmour } \\
\text { and Lewis }\end{array}$ & 2006 & $\begin{array}{l}\text { Examination of the Office of } \\
\text { Management and Budget's PART Scores } \\
\text { Does Performance }\end{array}$ & $\begin{array}{l}\text { Notwithstanding increasing enthusiasm for } \\
\text { performance budgeting, many problems limit its } \\
\text { implementation. The most important of these is } \\
\text { the unfeasibility of devising unbiased means of } \\
\text { translating performance information directly into } \\
\text { budgeting allocations. }\end{array}$ \\
\hline
\end{tabular}




\begin{tabular}{|c|c|c|c|}
\hline Author(s) & $\begin{array}{c}\text { Publication } \\
\text { Year }\end{array}$ & Title & Conclusion \\
\hline $\begin{array}{l}\text { 5. Hall and } \\
\text { Handley }\end{array}$ & 2011 & $\begin{array}{l}\text { City Adoption of Federal Performance } \\
\text { Measurement Requirements: Perspectives } \\
\text { from Community Development Block } \\
\text { Grant Program Administrators }\end{array}$ & $\begin{array}{l}\text { Partisan preferences play a role in the adoption of } \\
\text { a performance management system. }\end{array}$ \\
\hline 6. Hanes & 2017 & $\begin{array}{l}\text { Institutional Characteristics That Lead to } \\
\text { Increased Student Success Points for } \\
\text { Community Colleges In Texas }\end{array}$ & $\begin{array}{l}\text { Two institutional characteristics do significantly } \\
\text { affect the number of student success points } \\
\text { received by community colleges. }\end{array}$ \\
\hline $\begin{array}{l}\text { 7. Lam and } \\
\text { Wang }\end{array}$ & 2014 & $\begin{array}{l}\text { The Cognitive Foundation of a Co- } \\
\text { Production Approach to Performance } \\
\text { Measurement: How Do Officials and } \\
\text { Citizens Understand Government } \\
\text { Performance in China? }\end{array}$ & $\begin{array}{l}\text { Citizens' opinions are relevant when it comes to } \\
\text { the adoption of a PMS. }\end{array}$ \\
\hline $\begin{array}{l}\text { 8. Lu, } \\
\text { Willoughby, } \\
\text { and Arnett }\end{array}$ & 2009 & $\begin{array}{l}\text { Legislating Results: Examining the Legal } \\
\text { Foundations of PBB Systems in The } \\
\text { States }\end{array}$ & $\begin{array}{l}\text { States that do not use performance information } \\
\text { are less likely to adopt a PBF law. }\end{array}$ \\
\hline $\begin{array}{l}\text { 9. McKinney } \\
\text { and } \\
\text { Hagedorn }\end{array}$ & 2015 & $\begin{array}{l}\text { Performance-Based Funding for } \\
\text { Community Colleges in Texas: Are } \\
\text { Colleges Disadvantaged by Serving The } \\
\text { Most Disadvantaged Students? }\end{array}$ & Funding allocation associated with PBF matters. \\
\hline $\begin{array}{l}\text { 10. Melkers and } \\
\text { Willoughby }\end{array}$ & 2001 & $\begin{array}{l}\text { Budgeters' Views of State Performance- } \\
\text { Budgeting Systems: Distinctions Across } \\
\text { Branches }\end{array}$ & $\begin{array}{l}\text { Implementation of performance-based budgeting } \\
\text { systems is happening gradually. Results show } \\
\text { that opposing views of use and achievement } \\
\text { among budget players, particularly across } \\
\text { branches of government, impacts the adoption of } \\
\text { a PBF. }\end{array}$ \\
\hline
\end{tabular}




\begin{tabular}{|c|c|c|c|}
\hline Author(s) & $\begin{array}{c}\text { Publication } \\
\text { Year }\end{array}$ & Title & Conclusion \\
\hline 11. Rabovsky & 2012 & $\begin{array}{l}\text { Accountability in Higher Education: } \\
\text { Exploring Impacts on State Budgets and } \\
\text { Institutional Spending Patterns }\end{array}$ & $\begin{array}{l}\text { In order to understand organizational } \\
\text { performance, it is important to understand } \\
\text { connections between policy design and } \\
\text { administrative processes. }\end{array}$ \\
\hline 12. Rabovsky & 2014 & $\begin{array}{l}\text { Support for Performance-Based Funding: } \\
\text { The Role of Political Ideology, } \\
\text { Performance, And Dysfunctional } \\
\text { Information Environments }\end{array}$ & $\begin{array}{l}\text { The partisanship of the state legislature, } \\
\text { organizational performance, and the political } \\
\text { ideology of university presidents are relevant } \\
\text { factors leading up to adoption of PBF. }\end{array}$ \\
\hline $\begin{array}{l}\text { 13. Sohn and } \\
\text { Bae }\end{array}$ & 2018 & $\begin{array}{l}\text { Do Public Employees "Game" } \\
\text { Performance Budgeting Systems? } \\
\text { Evidence from the Program Assessment } \\
\text { Rating Tool in Korea }\end{array}$ & $\begin{array}{l}\text { Executing a performance management system } \\
\text { using the carrot and stick approach, care must be } \\
\text { taken, in particular, on the stick approach. }\end{array}$ \\
\hline $\begin{array}{l}\text { 14. Walker, } \\
\text { Damanpour, } \\
\text { and Devece }\end{array}$ & 2011 & $\begin{array}{l}\text { Management Innovation and } \\
\text { Organizational Performance: The } \\
\text { Mediating Effect of Performance } \\
\text { Management }\end{array}$ & $\begin{array}{l}\text { The effect of management innovation on } \\
\text { organizational performance is fully mediated by } \\
\text { performance management. }\end{array}$ \\
\hline $\begin{array}{l}\text { 15. Yang and } \\
\text { Hsieh }\end{array}$ & 2007 & $\begin{array}{l}\text { Managerial Effectiveness of Government } \\
\text { Performance Measurement: Testing A } \\
\text { Middle Range Model }\end{array}$ & $\begin{array}{l}\text { External political support affects performance } \\
\text { measurement adoption indirectly through } \\
\text { organizational support and technical training. }\end{array}$ \\
\hline
\end{tabular}


Table 4. Use of Performance Information Studies

\begin{tabular}{|c|c|c|c|}
\hline Author(s) & $\begin{array}{c}\text { Publication } \\
\text { Year }\end{array}$ & Title & Conclusion \\
\hline $\begin{array}{l}\text { 1. Angiola and } \\
\text { Bianchi }\end{array}$ & 2015 & $\begin{array}{l}\text { Public Managers' Skills } \\
\text { Development for Effective } \\
\text { Performance Management. } \\
\text { Empirical Evidence from Italian } \\
\text { Local Governments. }\end{array}$ & The level of performance utilization was not very high. \\
\hline $\begin{array}{l}\text { 2. Bischoff } \\
\text { and } \\
\text { Blaeschke }\end{array}$ & 2016 & $\begin{array}{l}\text { Performance Budgeting: } \\
\text { Incentives and Social Waste } \\
\text { from Window Dressing }\end{array}$ & PB induces massive social waste from window dressing. \\
\hline $\begin{array}{l}\text { 3. Bourdeax } \\
\text { and Chikoto }\end{array}$ & 2008 & $\begin{array}{l}\text { Legislative Influences on } \\
\text { Performance Management } \\
\text { Reform }\end{array}$ & $\begin{array}{l}\text { Professional legislatures and the quality of legislative } \\
\text { involvement results in higher utilization. }\end{array}$ \\
\hline $\begin{array}{l}\text { 4. Dimitrijevsk } \\
\text { a-Markoski } \\
\text { and French }\end{array}$ & 2019 & $\begin{array}{l}\text { Determinants of Public } \\
\text { Administrators' Use of } \\
\text { Performance Information: } \\
\text { Evidence from Local } \\
\text { Governments in Florida }\end{array}$ & $\begin{array}{l}\text { Institutionalization of performance measurement has the } \\
\text { strongest statistically significant positive association with } \\
\text { the use of performance information. }\end{array}$ \\
\hline $\begin{array}{l}\text { 5. Follz, } \\
\text { Abdelrazek, } \\
\text { and Chung }\end{array}$ & 2009 & $\begin{array}{l}\text { The Adoption, Use, and } \\
\text { Impacts of Performance } \\
\text { Measures in Medium-Size } \\
\text { Cities: Progress Toward } \\
\text { Performance Management }\end{array}$ & $\begin{array}{l}\text { This study finds that among mid-sized U.S. } \\
\text { municipalities, the use of performance measures is more } \\
\text { pervasive than ever. }\end{array}$ \\
\hline
\end{tabular}




\begin{tabular}{|c|c|c|c|}
\hline Author(s) & $\begin{array}{c}\text { Publication } \\
\text { Year }\end{array}$ & Title & Conclusion \\
\hline $\begin{array}{l}\text { 6. Gerrish and } \\
\text { Spreen }\end{array}$ & 2017 & $\begin{array}{l}\text { Does Benchmarking Encourage } \\
\text { Improvement or Convergence? } \\
\text { Evaluating North Carolina's } \\
\text { Fiscal Benchmarking Tool }\end{array}$ & $\begin{array}{l}\text { Local governments respond to financial performance } \\
\text { information by giving in to isomorphic pressures. }\end{array}$ \\
\hline 7. Gerrish & 2017 & $\begin{array}{l}\text { The Effect of the Child Support } \\
\text { Performance and Incentive Act } \\
\text { of } 1998 \text { on Rewarded and } \\
\text { Unrewarded Performance Goals }\end{array}$ & $\begin{array}{l}\text { Performance incentives do result in the improvement of } \\
\text { public sector performance. It also suggests that reforming } \\
\text { performance systems in response to perceived problems } \\
\text { may create unintended consequences, such as adverse } \\
\text { behavior to alter results. }\end{array}$ \\
\hline $\begin{array}{l}\text { 8. Gill, } \\
\text { Kengmama, } \\
\text { and Laking }\end{array}$ & 2012 & $\begin{array}{l}\text { Statistical Analysis of the } \\
\text { Managing for Organizational } \\
\text { Performance Survey }\end{array}$ & $\begin{array}{l}\text { The survey respondents make extensive use of numerical } \\
\text { and organizational information for managing } \\
\text { performance. }\end{array}$ \\
\hline $\begin{array}{l}\text { 9. Gilmour } \\
\text { and Lewis }\end{array}$ & 2005 & $\begin{array}{l}\text { Assessing Performance } \\
\text { Budgeting at OMB: The } \\
\text { Influence of Politics, } \\
\text { Performance, and Program Size }\end{array}$ & $\begin{array}{l}\text { Performance and results do not play as obvious a role as } \\
\text { might be anticipated. }\end{array}$ \\
\hline $\begin{array}{l}\text { 10. Gilmour } \\
\text { and Lewis }\end{array}$ & 2006 & $\begin{array}{l}\text { Does Performance Budgeting } \\
\text { Work? An Examination of the } \\
\text { Office of Management and } \\
\text { Budget's PART Scores }\end{array}$ & $\begin{array}{l}\text { Notwithstanding increasing enthusiasm for performance } \\
\text { budgeting, many problems limit its implementation. The } \\
\text { most important of these is the unfeasibility of devising } \\
\text { unbiased means of translating performance information } \\
\text { directly into budgeting allocations. }\end{array}$ \\
\hline 11. Heinrich & 2002 & $\begin{array}{l}\text { Outcomes-Based Performance } \\
\text { Management in the Public } \\
\text { Sector: Implications for } \\
\text { Government Accountability and } \\
\text { Effectiveness }\end{array}$ & $\begin{array}{l}\text { The use of administrative data in performance } \\
\text { management is improbable in generating precise } \\
\text { estimations of accurate program impacts. But these data } \\
\text { can still produce valuable information for public managers } \\
\text { about policy levers that can be employed to advance } \\
\text { organizational performance. }\end{array}$ \\
\hline
\end{tabular}




\begin{tabular}{|c|c|c|c|}
\hline Author(s) & $\begin{array}{c}\text { Publication } \\
\text { Year }\end{array}$ & Title & Conclusion \\
\hline 12. Heinrich & 2009 & $\begin{array}{l}\text { Third-Party Governance Under } \\
\text { No Child Left Behind: } \\
\text { Accountability and } \\
\text { Performance Management } \\
\text { Challenges }\end{array}$ & $\begin{array}{l}\text { Accurately measuring the performance of individual } \\
\text { providers in increasing student achievement is very } \\
\text { difficult to accomplish in practice. }\end{array}$ \\
\hline 13. Но & 2011 & $\begin{array}{l}\text { PBB in American Local } \\
\text { Governments: It's More than a } \\
\text { Management Tool }\end{array}$ & $\begin{array}{l}\text { PBB can be perceived more positively and generally as an } \\
\text { essential part of a management and budgeting reform with } \\
\text { real program and service appeal. }\end{array}$ \\
\hline 14. Hong & 2018 & $\begin{array}{l}\text { A Behavioral Model of Public } \\
\text { Organizations: Bounded } \\
\text { Rationality, Performance } \\
\text { Feedback, and Negativity Bias }\end{array}$ & $\begin{array}{l}\text { The results show that providing performance feedback } \\
\text { may have a noteworthy influence on public organizations' } \\
\text { motivation for future performance improvement. }\end{array}$ \\
\hline $\begin{array}{l}\text { 15. Hvidman } \\
\text { and } \\
\text { Andersen }\end{array}$ & 2013 & $\begin{array}{l}\text { Impact of Performance } \\
\text { Management in Public and } \\
\text { Private Organizations }\end{array}$ & $\begin{array}{l}\text { Management matters differently in public and private } \\
\text { organizations. }\end{array}$ \\
\hline 16. Kroll & 2017 & $\begin{array}{l}\text { Can Performance Management } \\
\text { Foster Social Equity? } \\
\text { Stakeholder Power, Protective } \\
\text { Institutions, And Minority } \\
\text { Representation }\end{array}$ & $\begin{array}{l}\text { Performance information use is more likely to benefit } \\
\text { disadvantaged groups if these groups are large and } \\
\text { influential. It is less probable to hurt underprivileged } \\
\text { interests if formal shielding institutions exist that } \\
\text { decision-makers consider relevant. }\end{array}$ \\
\hline $\begin{array}{l}\text { 17. Lavertu and } \\
\text { Moynihan }\end{array}$ & 2012 & $\begin{array}{l}\text { Agency Political Ideology and } \\
\text { Reform Implementation: } \\
\text { Performance Management in } \\
\text { the Bush Administration }\end{array}$ & $\begin{array}{l}\text { Managers who report greater participation in the PART } \\
\text { review process also report greater use of performance } \\
\text { information. }\end{array}$ \\
\hline
\end{tabular}




\begin{tabular}{|c|c|c|c|}
\hline Author(s) & $\begin{array}{c}\text { Publication } \\
\text { Year }\end{array}$ & Title & Conclusion \\
\hline $\begin{array}{l}\text { 18. Lu, } \\
\text { Willoughby, } \\
\text { and Arnett }\end{array}$ & 2009 & $\begin{array}{l}\text { Legislating Results: Examining } \\
\text { the Legal Foundations of PBB } \\
\text { Systems in the States }\end{array}$ & $\begin{array}{l}\text { States that make robust use of performance information } \\
\text { for resource allocation decisions tend to establish legal } \\
\text { foundations that stipulate how measurement will be } \\
\text { incorporated into the budget process. }\end{array}$ \\
\hline 19. Holm & 2018 & $\begin{array}{l}\text { Successful Problem Solvers? } \\
\text { Managerial Performance } \\
\text { Information Used to Improve } \\
\text { Low Organizational } \\
\text { Performance }\end{array}$ & Performance gains require constant perseverance. \\
\hline $\begin{array}{l}\text { 20. Marvel and } \\
\text { Marvel }\end{array}$ & 2007 & $\begin{array}{l}\text { Outsourcing Oversight: A } \\
\text { Comparison of Monitoring for } \\
\text { In-House and Contracted } \\
\text { Services }\end{array}$ & $\begin{array}{l}\text { Services provided internally by a government's own } \\
\text { employees are indeed monitored intensively by the } \\
\text { contracting government. }\end{array}$ \\
\hline 21. Melkers & 2006 & $\begin{array}{l}\text { On the Road to Improved } \\
\text { Performance: Changing } \\
\text { Organizational Communication } \\
\text { through Performance } \\
\text { Management }\end{array}$ & $\begin{array}{l}\text { Real progress has been made in terms of changing } \\
\text { organizational cultures in state and local governments to } \\
\text { make use of performance measurement. }\end{array}$ \\
\hline 22. Moynihan & 2006 & $\begin{array}{l}\text { What Do We Talk about When } \\
\text { We Talk about Performance? } \\
\text { Dialogue Theory and } \\
\text { Performance Budgeting }\end{array}$ & $\begin{array}{l}\text { Performance information is used, but the connotations } \\
\text { allocated to such data are biased and will be construed and } \\
\text { discussed among diverse actors in accordance with their } \\
\text { principles, education, incentives, partisan preferences, and } \\
\text { cognitive features. }\end{array}$ \\
\hline $\begin{array}{l}\text { 23. Moynihan } \\
\text { and Kroll }\end{array}$ & 2016 & $\begin{array}{l}\text { Performance Management } \\
\text { Routines that Work? An Early } \\
\text { Assessment of the GPRA } \\
\text { Modernization Act }\end{array}$ & $\begin{array}{l}\text { The Modernization Act is associated with the purposeful } \\
\text { use of performance data to manage programs and } \\
\text { employees and pinpoint and solve problems }\end{array}$ \\
\hline
\end{tabular}




\begin{tabular}{|c|c|l|l|}
\hline Author(s) & $\begin{array}{c}\text { Publication } \\
\text { Year }\end{array}$ & \multicolumn{1}{|c|}{ Title } & \multicolumn{1}{c|}{ Conclusion } \\
\hline $\begin{array}{c}\text { 24. Moynihan } \\
\text { and Lavertu }\end{array}$ & 2012 & $\begin{array}{l}\text { Does Involvement in } \\
\text { Performance Management } \\
\text { Routines Encourage } \\
\text { Performance Information Use? } \\
\text { Evaluating } \\
\text { GPRA and PART }\end{array}$ & $\begin{array}{l}\text { Managerial involvement in GPRA and PART has had a } \\
\text { direct impact on relatively few aspects of performance } \\
\text { information use. }\end{array}$ \\
$\begin{array}{c}\text { 25. Moynihan } \\
\text { and Pandey }\end{array}$ & 2005 & $\begin{array}{l}\text { Testing How Management } \\
\text { Matters in an Era of } \\
\text { Government by Performance } \\
\text { Management }\end{array}$ & $\begin{array}{l}\text { Management matters to performance, and it is reasonable } \\
\text { to expect managers to undertake actions to enhance } \\
\text { performance. }\end{array}$ \\
\hline $\begin{array}{c}\text { 26. Moynihan } \\
\text { and Pandey }\end{array}$ & 2010 & $\begin{array}{l}\text { The Big Question for } \\
\text { Performance Management: } \\
\text { Why Do Managers Use } \\
\text { Performance Information? }\end{array}$ & $\begin{array}{l}\text { Performance information use is more likely to be driven } \\
\text { by altruism rather than self-interest among government } \\
\text { office. }\end{array}$ \\
\hline $\begin{array}{c}\text { 27. Moynihan, } \\
\text { Lavertu, and } \\
\text { Kamensky }\end{array}$ & 2012 & $\begin{array}{l}\text { Does Involvement in } \\
\text { Performance Management } \\
\text { Routines Encourage } \\
\text { Performance Information Use? } \\
\text { Evaluating GPRA and PART } \\
\text { [with Commentary] }\end{array}$ & $\begin{array}{l}\text { GPRA and PART have been most effective in } \\
\text { encouraging passive forms of performance information } \\
\text { use. }\end{array}$ \\
\hline
\end{tabular}




\begin{tabular}{|c|c|c|c|}
\hline Author(s) & $\begin{array}{c}\text { Publication } \\
\text { Year }\end{array}$ & Title & Conclusion \\
\hline $\begin{array}{l}\text { 28. Onesti, } \\
\text { Nunzio, and } \\
\text { Bianchi }\end{array}$ & 2016 & $\begin{array}{l}\text { Learning by Using Performance } \\
\text { Measures in Local } \\
\text { Governments: The perspective } \\
\text { of Public Managers }\end{array}$ & $\begin{array}{l}\text { Executives in municipalities with a higher percentage of } \\
\text { enforcement measures are likely to be more mindful of the } \\
\text { significance of measuring and analyzing past performance } \\
\text { in order to reduce further potential financial losses. }\end{array}$ \\
\hline 29. Rabovsky & 2012 & $\begin{array}{l}\text { Accountability in Higher } \\
\text { Education: Exploring Impacts } \\
\text { on State Budgets and } \\
\text { Institutional Spending Patterns }\end{array}$ & $\begin{array}{l}\text { The link between performance information and funding } \\
\text { may already be more substantial than many observers are } \\
\text { currently aware. }\end{array}$ \\
\hline 30. Rabovsky & 2014 & $\begin{array}{l}\text { Using Data to Manage for } \\
\text { Performance at Public } \\
\text { Universities }\end{array}$ & $\begin{array}{l}\text { Organizational use of performance data is strongly related } \\
\text { to the political ideology of agency leaders. }\end{array}$ \\
\hline $\begin{array}{l}\text { 31. Rivenbank, } \\
\text { Fasiello, } \\
\text { and Adamo }\end{array}$ & 2019 & $\begin{array}{l}\text { Exploring Performance } \\
\text { Management in Italian Local } \\
\text { Government: The Necessity of } \\
\text { Outcome }\end{array}$ & $\begin{array}{l}\text { Local officials are more likely to engage in performance } \\
\text { data use when they embrace outcome measures and when } \\
\text { they increase the level of citizen participation. }\end{array}$ \\
\hline $\begin{array}{l}\text { 32. Soss, } \\
\text { Fording, } \\
\text { and Schram }\end{array}$ & 2011 & $\begin{array}{l}\text { The Organization of Discipline: } \\
\text { From } \\
\text { Performance Management to } \\
\text { Perversity and } \\
\text { Punishment }\end{array}$ & $\begin{array}{l}\text { Strong performance pressures promote the use of } \\
\text { sanctions to discipline the poor because they are a form of } \\
\text { coercive power. }\end{array}$ \\
\hline
\end{tabular}




\begin{tabular}{|c|c|l|l|}
\hline Author(s) & $\begin{array}{c}\text { Publication } \\
\text { Year }\end{array}$ & \multicolumn{1}{|c|}{ Title } & \multicolumn{1}{c|}{ Conclusion } \\
\hline $\begin{array}{c}\text { 33. Vogel and } \\
\text { Hattke }\end{array}$ & 2018 & $\begin{array}{l}\text { How is the Use of Performance } \\
\text { Information Related to } \\
\text { Performance of } \\
\text { Public Sector Professionals? } \\
\text { Evidence } \\
\text { from the Field of Academic } \\
\text { Research }\end{array}$ & $\begin{array}{l}\text { The publication output of researchers does not } \\
\text { significantly vary with the perceived use of performance } \\
\text { information in their institutions }\end{array}$ \\
$\begin{array}{c}\text { 34. Wang and } \\
\text { Yeung }\end{array}$ & $\begin{array}{l}\text { Testing the Effectiveness of } \\
\text { "Managing for } \\
\text { Results": Evidence from an } \\
\text { Education Policy } \\
\text { Innovation in New York City }\end{array}$ & $\begin{array}{l}\text { EZ reform that gave } \\
\text { principals more managerial authority and autonomy in } \\
\text { return for accountability significantly improved some } \\
\text { performance measures of public schools; the effect of } \\
\text { MFR is not constant over time. }\end{array}$ \\
\hline
\end{tabular}


Table 5. Impact Studies

\begin{tabular}{|c|c|c|c|c|c|}
\hline Author(s) & $\begin{array}{l}\text { Publicatio } \\
\text { n Year }\end{array}$ & Title & Impact Type & Conclusion & $\begin{array}{l}\text { Factors that contributed } \\
\text { to the type of impact }\end{array}$ \\
\hline 1. Andersen & 2008 & $\begin{array}{l}\text { The Impact of } \\
\text { Public } \\
\text { Management } \\
\text { Reforms on } \\
\text { Student } \\
\text { Performance in } \\
\text { Danish Schools }\end{array}$ & $\begin{array}{l}\text { Mixed results } \\
\text { Unintended } \\
\text { consequences }\end{array}$ & $\begin{array}{l}\text { Minimal support to the } \\
\text { expectation that } \\
\text { performance management } \\
\text { systems improve } \\
\text { performance measured as } \\
\text { exam scores, but highly } \\
\text { significant effects on } \\
\text { inequity. } \\
\text { Monitor the potential side- } \\
\text { effects of adopting } \\
\text { performance management } \\
\text { systems. }\end{array}$ & $\begin{array}{l}\text { Contradictions and } \\
\text { dilemmas } \\
\text { decentralization/centraliz } \\
\text { ation and } \\
\text { autonomy/control that are } \\
\text { inherent in performance } \\
\text { management reforms. } \\
\text { Ambiguity in terms of } \\
\text { implementation. } \\
\text { Not enough time has } \\
\text { passed to evaluate the } \\
\text { impact. }\end{array}$ \\
\hline 2. Barnow & 2000 & $\begin{array}{l}\text { Exploring the } \\
\text { Relationship } \\
\text { Between } \\
\text { Performance } \\
\text { Management and } \\
\text { Program Impact: A } \\
\text { Case Study of The } \\
\text { Job Training } \\
\text { Partnership Act }\end{array}$ & Weak results & $\begin{array}{l}\text { There is only a weak } \\
\text { correspondence between the } \\
\text { two performance measures. }\end{array}$ & $\begin{array}{l}\text { Sample not large enough. } \\
\text { Measures of performance } \\
\text { and impact may not be } \\
\text { accurate. }\end{array}$ \\
\hline
\end{tabular}




\begin{tabular}{|c|c|c|c|c|c|}
\hline Author(s) & $\begin{array}{l}\text { Publicatio } \\
\text { n Year }\end{array}$ & Title & Impact Type & Conclusion & $\begin{array}{l}\text { Factors that contributed } \\
\text { to the type of impact }\end{array}$ \\
\hline 3. Birdsall & 2018 & $\begin{array}{l}\text { Performance } \\
\text { Management in } \\
\text { Public Higher } \\
\text { Education: } \\
\text { Unintended } \\
\text { Consequences and } \\
\text { The Implications } \\
\text { of Organizational } \\
\text { Diversity }\end{array}$ & $\begin{array}{l}\text { Mixed results } \\
\text { Unintended } \\
\text { consequences }\end{array}$ & $\begin{array}{l}\text { Effects vary depending on } \\
\text { institutions' dependence on } \\
\text { state funding. } \\
\text { Institutions may fulfil } \\
\text { performance improvements } \\
\text { at the expense of other } \\
\text { significant values. }\end{array}$ & $\begin{array}{l}\text { Organizational } \\
\text { differences (mission, } \\
\text { culture, and resources). } \\
\text { State dependence on } \\
\text { performance funding } \\
\text { affects responses to } \\
\text { performance funding. }\end{array}$ \\
\hline $\begin{array}{l}\text { 4. Bischoff } \\
\text { and } \\
\text { Blaeschke }\end{array}$ & 2016 & $\begin{array}{l}\text { Performance } \\
\text { Budgeting: } \\
\text { Incentives and } \\
\text { Social Waste from } \\
\text { Window Dressing }\end{array}$ & $\begin{array}{l}\text { Symbolic } \\
\text { purposes }\end{array}$ & $\begin{array}{l}\text { PB induces massive social } \\
\text { waste from window } \\
\text { dressing. }\end{array}$ & $\begin{array}{l}\text { Imperfect performance } \\
\text { measures. } \\
\text { Proxy information. }\end{array}$ \\
\hline $\begin{array}{l}\text { 5. Favero and } \\
\text { Rutherford }\end{array}$ & 2019 & $\begin{array}{l}\text { Will the Tide Lift } \\
\text { All Boats? } \\
\text { Examining the } \\
\text { Equity Effects of } \\
\text { Performance } \\
\text { Funding Policies } \\
\text { in U.S. Higher } \\
\text { Education }\end{array}$ & $\begin{array}{l}\text { Mixed results } \\
\text { Unintended } \\
\text { consequences }\end{array}$ & $\begin{array}{l}\text { Performance funding } \\
\text { policies result in } \\
\text { improvement of overall } \\
\text { degree production but have } \\
\text { no statistically significant } \\
\text { association with graduation } \\
\text { or retention rates. The } \\
\text { distributional effects of } \\
\text { performance funding } \\
\text { policies across institutions } \\
\text { should be considered with } \\
\text { regard to winners and } \\
\text { losers. }\end{array}$ & $\begin{array}{l}\text { Data availability. } \\
\text { Coding. } \\
\text { Institutional } \\
\text { characteristics. More } \\
\text { selective schools benefit } \\
\text { more. } \\
\text { Incentives/rewards } \\
\text { granted to top } \\
\text { performers. }\end{array}$ \\
\hline
\end{tabular}




\begin{tabular}{|c|c|c|c|c|c|}
\hline Author(s) & $\begin{array}{l}\text { Publicatio } \\
\text { n Year }\end{array}$ & Title & Impact Type & Conclusion & $\begin{array}{l}\text { Factors that contributed } \\
\text { to the type of impact }\end{array}$ \\
\hline & & & & & $\begin{array}{l}\text { Measurement: to find a } \\
\text { way to capture all the } \\
\text { factors that would } \\
\text { increase the institution's } \\
\text { ability to hit the } \\
\text { benchmarks. }\end{array}$ \\
\hline $\begin{array}{l}\text { 6. Gerrish and } \\
\text { Spreen }\end{array}$ & 2017 & $\begin{array}{l}\text { Does } \\
\text { Benchmarking } \\
\text { Encourage } \\
\text { Improvement or } \\
\text { Convergence? } \\
\text { Evaluating North } \\
\text { Carolina's Fiscal } \\
\text { Benchmarking To } \\
\text { ol }\end{array}$ & $\begin{array}{l}\text { Unintended } \\
\text { consequences }\end{array}$ & $\begin{array}{l}\text { Be mindful of the } \\
\text { unintended consequences } \\
\text { associated with } \\
\text { fiscal benchmarking and } \\
\text { performance information. }\end{array}$ & $\begin{array}{l}\text { Lack of guidance about } \\
\text { how to use performance } \\
\text { information. }\end{array}$ \\
\hline 7. Gerrish & 2016 & $\begin{array}{l}\text { The Impact of } \\
\text { Performance } \\
\text { Management on } \\
\text { Performance in } \\
\text { Public } \\
\text { Organizations: A } \\
\text { Meta-Analysis }\end{array}$ & $\begin{array}{l}\text { Small but } \\
\text { positive } \\
\text { Gaming } \\
\text { behavior } \\
\text { Time matters }\end{array}$ & $\begin{array}{l}\text { Performance management } \\
\text { systems tend to have a small } \\
\text { but positive average impact } \\
\text { on performance in public } \\
\text { organizations. Because of } \\
\text { changing organizational } \\
\text { goals or gaming behavior, } \\
\text { performance management } \\
\text { systems must evolve over } \\
\text { time to keep pace. }\end{array}$ & $\begin{array}{l}\text { Use of performance } \\
\text { management best } \\
\text { practices. }\end{array}$ \\
\hline
\end{tabular}




\begin{tabular}{|c|c|c|c|c|c|}
\hline Author(s) & $\begin{array}{l}\text { Publicatio } \\
\text { n Year }\end{array}$ & Title & Impact Type & Conclusion & $\begin{array}{l}\text { Factors that contributed } \\
\text { to the type of impact }\end{array}$ \\
\hline 8. Gerrish & 2017 & $\begin{array}{l}\text { The Effect of the } \\
\text { Child Support } \\
\text { Performance and } \\
\text { Incentive Act Of } \\
1998 \text { on Rewarded } \\
\text { and Unrewarded } \\
\text { Performance Goals }\end{array}$ & $\begin{array}{l}\text { Mixed results } \\
\text { Gaming } \\
\text { response }\end{array}$ & $\begin{array}{l}\text { The Child Support } \\
\text { Performance Incentive Act } \\
\text { (CSPIA) has had little } \\
\text { impact on Child Support } \\
\text { Enforcement (CSE) } \\
\text { performance; two of the } \\
\text { explicit performance } \\
\text { measures increased } \\
\text { modestly after CSPIA, } \\
\text { while one of the child } \\
\text { support outcomes saw a } \\
\text { substantial decline, } \\
\text { suggesting a gaming } \\
\text { response. }\end{array}$ & $\begin{array}{l}\text { First, state organizations } \\
\text { may not use performance } \\
\text { information effectively, } \\
\text { or financial rewards } \\
\text { reduce the intrinsic or } \\
\text { public service motivation } \\
\text { of state child support } \\
\text { officials. } \\
\text { Additionally, state } \\
\text { introspection on in-state } \\
\text { cases has apparently } \\
\text { hampered interstate } \\
\text { cooperation, resulting in } \\
\text { a decline in interstate } \\
\text { collections. }\end{array}$ \\
\hline $\begin{array}{l}\text { 9. Gilmour } \\
\text { and Lewis }\end{array}$ & 2005 & $\begin{array}{l}\text { Assessing } \\
\text { Performance } \\
\text { Budgeting At } \\
\text { OMB: The } \\
\text { Influence of } \\
\text { Politics, } \\
\text { Performance, and } \\
\text { Program Size }\end{array}$ & Small impact & $\begin{array}{l}\text { The "results" component } \\
\text { of PART scores has a } \\
\text { smaller impact on budget } \\
\text { decisions than the } \\
\text { "program purpose" } \\
\text { component, a finding that } \\
\text { tends to contradict the goal } \\
\text { of performance budgeting to } \\
\text { redirect resources to } \\
\text { programs that produce } \\
\text { results. }\end{array}$ & $\begin{array}{l}\text { Shortage of good } \\
\text { performance measures. } \\
\text { Lack of good measures } \\
\text { for results. }\end{array}$ \\
\hline
\end{tabular}




\begin{tabular}{|c|c|c|c|c|c|}
\hline Author(s) & $\begin{array}{l}\text { Publicatio } \\
\text { n Year }\end{array}$ & Title & Impact Type & Conclusion & $\begin{array}{l}\text { Factors that contributed } \\
\text { to the type of impact }\end{array}$ \\
\hline $\begin{array}{l}\text { 10. Gilmour } \\
\text { and Lewis }\end{array}$ & 2006 & $\begin{array}{l}\text { Does Performance } \\
\text { Budgeting Work? } \\
\text { An Examination of } \\
\text { The Office of } \\
\text { Management and } \\
\text { Budget's PART } \\
\text { Scores }\end{array}$ & Mixed & $\begin{array}{l}\text { The Bush Administration's } \\
\text { management scores were } \\
\text { positively correlated with } \\
\text { proposed budgets for } \\
\text { programs housed in } \\
\text { traditionally Democratic } \\
\text { departments but not in other } \\
\text { departments. }\end{array}$ & $\begin{array}{l}\text { The impossibility of } \\
\text { devising an automatic or } \\
\text { impartial means of } \\
\text { translating performance } \\
\text { information directly } \\
\text { into budgeting } \\
\text { allocations. } \\
\text { Political preferences may } \\
\text { interfere in budget } \\
\text { allocations. }\end{array}$ \\
\hline 11. Heinrich & 2009 & $\begin{array}{l}\text { Third-Party } \\
\text { Governance Under } \\
\text { No Child Left } \\
\text { Behind: } \\
\text { Accountability and } \\
\text { Performance } \\
\text { Management } \\
\text { Challenges }\end{array}$ & Positive & $\begin{array}{l}\text { No Child Left Behind } \\
\text { (NCLB) advanced stronger } \\
\text { accountability for student } \\
\text { performance as the primary } \\
\text { management process } \\
\text { requiring Supplemental } \\
\text { Educational Services (SES) } \\
\text { providers that failed to } \\
\text { increase students' academic } \\
\text { achievement over a 2-year } \\
\text { period. }\end{array}$ & $\begin{array}{l}\text { Clear-cut and widely } \\
\text { accepted measures by } \\
\text { which to evaluate } \\
\text { program effectiveness. }\end{array}$ \\
\hline 12. Hillman & 2018 & $\begin{array}{l}\text { The Equity } \\
\text { Implications of } \\
\text { Paying for } \\
\text { Performance in } \\
\text { Higher Education }\end{array}$ & $\begin{array}{l}\text { Unintended } \\
\text { consequences }\end{array}$ & $\begin{array}{l}\text { The findings presented } \\
\text { show that in some of the } \\
\text { nation's most aggressive } \\
\text { performance funding states, } \\
\text { racial/ethnic minority }\end{array}$ & $\begin{array}{l}\text { States rarely embed } \\
\text { bonuses for serving } \\
\text { students of color. }\end{array}$ \\
\hline
\end{tabular}




\begin{tabular}{|c|c|c|c|c|c|}
\hline Author(s) & $\begin{array}{l}\text { Publicatio } \\
\text { n Year }\end{array}$ & Title & Impact Type & Conclusion & $\begin{array}{l}\text { Factors that contributed } \\
\text { to the type of impact }\end{array}$ \\
\hline & & & & $\begin{array}{l}\text { serving institutions tend to } \\
\text { lose funding. }\end{array}$ & \\
\hline $\begin{array}{l}\text { 13. Hillman, } \\
\text { Tandberg, } \\
\text { and Fryar }\end{array}$ & 2015 & $\begin{array}{l}\text { Evaluating the } \\
\text { Impacts of "New" } \\
\text { Performance } \\
\text { Funding in Higher } \\
\text { Education }\end{array}$ & No effects & $\begin{array}{l}\text { The performance of } \\
\text { Washington community and } \\
\text { technical colleges was often } \\
\text { not different from } \\
\text { the performance of colleges } \\
\text { in other states that were } \\
\text { never subject to similar } \\
\text { accountability policies. }\end{array}$ & $\begin{array}{l}\text { Underestimation of } \\
\text { factors that affect the } \\
\text { performance outcomes. } \\
\text { Lack of internal capacity } \\
\text { at the home institutions. } \\
\text { Steps necessary to } \\
\text { improve outcomes are } \\
\text { complex. } \\
\text { Financial incentives with } \\
\text { performance system were } \\
\text { low. }\end{array}$ \\
\hline $\begin{array}{l}\text { 14. Lam and } \\
\text { Wang }\end{array}$ & 2014 & $\begin{array}{l}\text { The Cognitive } \\
\text { Foundation of a } \\
\text { Co-Production } \\
\text { Approach to } \\
\text { Performance } \\
\text { Measurement: } \\
\text { How Do Officials } \\
\text { and Citizens } \\
\text { Understand }\end{array}$ & Positive & $\begin{array}{l}\text { Both citizens and officials } \\
\text { agreed that there were } \\
\text { enhancements in the } \\
\text { performance of the } \\
\text { environmental protection } \\
\text { agencies and the education } \\
\text { agencies in the three cities. }\end{array}$ & $\begin{array}{l}\text { Citizens assessed } \\
\text { performance by intuition, } \\
\text { not by the actual } \\
\text { performance measures. }\end{array}$ \\
\hline
\end{tabular}




\begin{tabular}{|c|c|c|c|c|c|}
\hline Author(s) & $\begin{array}{l}\text { Publicatio } \\
\text { n Year }\end{array}$ & Title & Impact Type & Conclusion & $\begin{array}{l}\text { Factors that contributed } \\
\text { to the type of impact }\end{array}$ \\
\hline & & $\begin{array}{l}\text { Government } \\
\text { Performance in } \\
\text { China? }\end{array}$ & & & \\
\hline $\begin{array}{l}\text { 15. Li and } \\
\text { Kennedy }\end{array}$ & 2018 & $\begin{array}{l}\text { Performance } \\
\text { Funding Policy } \\
\text { Effects on } \\
\text { Community } \\
\text { College Outcomes: } \\
\text { Are Short-Term } \\
\text { Certificates on The } \\
\text { Rise? }\end{array}$ & No changes & $\begin{array}{l}\text { Performance funding } \\
\text { produced no significant } \\
\text { changes in completions of } \\
\text { any of the three credentials. }\end{array}$ & $\begin{array}{l}\text { Policies that are more } \\
\text { likely to produce changes } \\
\text { are those that have } \\
\text { distributed funding for } \\
\text { more than } 2 \text { fiscal years, } \\
\text { tie a higher proportion of } \\
\text { base state funding } \\
\text { to performance } \\
\text { outcomes, differentiate } \\
\text { performance metrics by } \\
\text { college mission, cover } \\
\text { 2- and 4-year sectors, } \\
\text { and/or incorporate } \\
\text { metrics that account for } \\
\text { different populations } \\
\text { served. }\end{array}$ \\
\hline 16. Pasha & 2018 & $\begin{array}{l}\text { Can Performance } \\
\text { Management Best } \\
\text { Practices Help } \\
\text { Reduce Crime? }\end{array}$ & Positive & $\begin{array}{l}\text { Performance management is } \\
\text { significantly related to } \\
\text { improvement in police } \\
\text { performance. }\end{array}$ & $\begin{array}{l}\text { Performance dimensions } \\
\text { that are amenable to } \\
\text { control. } \\
\text { Data manipulation. }\end{array}$ \\
\hline
\end{tabular}




\begin{tabular}{|c|c|c|c|c|c|}
\hline Author(s) & $\begin{array}{l}\text { Publicatio } \\
\text { n Year }\end{array}$ & Title & Impact Type & Conclusion & $\begin{array}{l}\text { Factors that contributed } \\
\text { to the type of impact }\end{array}$ \\
\hline $\begin{array}{l}\text { 17. Patrick and } \\
\text { Rollins }\end{array}$ & 2015 & $\begin{array}{l}\text { Assessing Public } \\
\text { Sector } \\
\text { Performance } \\
\text { Reforms and The } \\
\text { Plight of } \\
\text { Disadvantaged } \\
\text { Citizens }\end{array}$ & Positive & $\begin{array}{l}\text { Performance reforms } \\
\text { holding educators } \\
\text { accountable result in } \\
\text { enhancing performance. }\end{array}$ & $\begin{array}{l}\text { States previously had a } \\
\text { performance } \\
\text { management system in } \\
\text { place. }\end{array}$ \\
\hline $\begin{array}{l}\text { 18. Poister, } \\
\text { Pasha, and } \\
\text { Edwards }\end{array}$ & 2013 & $\begin{array}{l}\text { Does Performance } \\
\text { Management Lead } \\
\text { to Better } \\
\text { Outcomes? } \\
\text { Evidence from The } \\
\text { U.S. Public Transit } \\
\text { Industry }\end{array}$ & Positive & $\begin{array}{l}\text { More extensive use of } \\
\text { performance management } \\
\text { practices does in fact } \\
\text { contribute to increased } \\
\text { effectiveness in } \\
\text { the transit industry. }\end{array}$ & $\begin{array}{l}\text { Engaging more } \\
\text { proactively in what have } \\
\text { become conventional } \\
\text { performance } \\
\text { management practices. }\end{array}$ \\
\hline $\begin{array}{l}\text { 19. Poister, } \\
\text { Pasha, } \\
\text { DeGroff, } \\
\text { and } \\
\text { Royalty }\end{array}$ & 2018 & $\begin{array}{l}\text { The Impact of } \\
\text { Performance- } \\
\text { Based Grants } \\
\text { Management on } \\
\text { Performance: The } \\
\text { Centers for } \\
\text { Disease Control } \\
\text { and Prevention's } \\
\text { National Breast } \\
\text { and Cervical } \\
\text { Cancer Early } \\
\text { Detection Program }\end{array}$ & Positive & $\begin{array}{l}\text { These results tentatively } \\
\text { support the argument of } \\
\text { goal-setting theory that } \\
\text { establishing challenging } \\
\text { goals is helpful for } \\
\text { performance improvement. }\end{array}$ & $\begin{array}{l}\text { Political and public } \\
\text { attention. }\end{array}$ \\
\hline
\end{tabular}




\begin{tabular}{|c|c|c|c|c|c|}
\hline Author(s) & $\begin{array}{l}\text { Publicatio } \\
\text { n Year }\end{array}$ & Title & Impact Type & Conclusion & $\begin{array}{l}\text { Factors that contributed } \\
\text { to the type of impact }\end{array}$ \\
\hline 20. Rabovsky & 2012 & $\begin{array}{l}\text { Accountability in } \\
\text { Higher Education: } \\
\text { Exploring Impacts } \\
\text { on State Budgets } \\
\text { and Institutional } \\
\text { Spending Patterns }\end{array}$ & No effect & $\begin{array}{l}\text { The results failed to find } \\
\text { any substantial evidence } \\
\text { that performance-funding } \\
\text { policies have had significant } \\
\text { impacts on state budgets' } \\
\text { institutional priorities. }\end{array}$ & $\begin{array}{l}\text { Financial incentives are } \\
\text { not enough. } \\
\text { Variations in the nature } \\
\text { and content of the } \\
\text { performance } \\
\text { management system. }\end{array}$ \\
\hline $\begin{array}{l}\text { 21. Walker, } \\
\text { Jung, and } \\
\text { Boyne }\end{array}$ & 2013 & $\begin{array}{l}\text { Marching to } \\
\text { Different } \\
\text { Drummers? The } \\
\text { Performance } \\
\text { Effects of } \\
\text { Alignment } \\
\text { between Political } \\
\text { and Managerial } \\
\text { Perceptions of } \\
\text { Performance } \\
\text { Management }\end{array}$ & Positive & $\begin{array}{l}\text { Performance management is } \\
\text { associated with } \\
\text { better organizational } \\
\text { performance. }\end{array}$ & $\begin{array}{l}\text { High degree of role } \\
\text { flexibility and high trust } \\
\text { between politician and } \\
\text { officers. }\end{array}$ \\
\hline $\begin{array}{l}\text { 22. Wang and } \\
\text { Yeung }\end{array}$ & 2019 & $\begin{array}{l}\text { Testing the } \\
\text { Effectiveness of } \\
\text { "Managing for } \\
\text { Results": Evidence } \\
\text { from An Education } \\
\text { Policy Innovation } \\
\text { In New York City }\end{array}$ & Mixed Results & $\begin{array}{l}\text { EZ reform that gave } \\
\text { principals more managerial } \\
\text { authority and autonomy in } \\
\text { return for accountability } \\
\text { significantly improved some } \\
\text { performance measures of } \\
\text { public schools; the effect } \\
\text { was not constant over time. }\end{array}$ & $\begin{array}{l}\text { More managerial } \\
\text { autonomy and authority. } \\
\text { Performance targets give } \\
\text { managers a clear } \\
\text { direction to go and } \\
\text { motivate them to work } \\
\text { toward achieving targets. }\end{array}$ \\
\hline
\end{tabular}




\begin{tabular}{|c|c|l|l|l|l|}
\hline Author(s) & $\begin{array}{c}\text { Publicatio } \\
\text { n Year }\end{array}$ & \multicolumn{1}{|c|}{ Title } & Impact Type & Conclusion & $\begin{array}{l}\text { Factors that contributed } \\
\text { to the type of impact }\end{array}$ \\
\hline & & & $\begin{array}{l}\text { Organizational cheating } \\
\text { or gaming might be a } \\
\text { side effect. }\end{array}$ \\
\begin{tabular}{|l} 
23. Yang and \\
Kassekert
\end{tabular} & \multirow{2}{*}{2010} & $\begin{array}{l}\text { Linking } \\
\text { Management } \\
\text { Reform with } \\
\text { Employee Job } \\
\text { Satisfaction: } \\
\text { Evidence from } \\
\text { Federal Agencies }\end{array}$ & Positive & $\begin{array}{l}\text { Managing for results is } \\
\text { positively related to job } \\
\text { satisfaction. }\end{array}$ & $\begin{array}{l}\text { The same NPM-type of } \\
\text { logic: with more } \\
\text { personnel management } \\
\text { flexibility agencies and } \\
\text { managers can improve } \\
\text { performance and } \\
\text { satisfaction. }\end{array}$ \\
\hline
\end{tabular}


Table 6 summarizes the factors that influenced the impact type of the selected papers. The studies were categorized based on impact type and were coded based on the factors that led to this impact. The factors were identified following inductive reasoning. Creswell and Plano Clark (2007) defined an inductive researcher as "someone who works from the bottom-up, using the participant's views to build broader themes and generate a theory interconnecting themes" (p. 23). Inductive reasoning is a qualitative research attribute because it shifts from very clear-cut observations to much more extensive generalizations (Soiferman, 2010). In the case of the present study, measurement emerged as an important factor-several papers cited measurement as a factor, and several cited it under different impact types. In addition, incentives associated with the PMS and political support were among the most cited factors in more than one impact type.

For cases with mixed results impact, the factors affecting impact varied widely. They were related to the configuration of the PMS (e.g., ambiguity, coding, and incentives), political and state factors, and organizational factors (e.g., mission, culture, and management). For cases in which impact was categorized as purely symbolic or weak, the factors were related to the PMS scope (such as measurement and data). Not surprisingly, for cases in which impact was categorized as yielding unintended consequences, the factors were lack of direction and absence of incentives. These were all external factors and not specific to the organization. In terms of no effect, the factors were primarily related to the system itself (e.g., incentives, model variations, funding). Finally, positive results ranged widely—from quality of the measures, which is a PMS characteristic, to data manipulation and citizen perceptions. It is not a coincidence that 
factors leading to positive results are much broader than for the other impact types. If researchers and officials had a concrete understanding of the factors that resulted in positive results, the research literature would be indicative of positive results. As this research shows, this is not the case. The literature is overwhelmingly lacking evidence of positive results.

Table 6. Factors that led to the Impact Type

Impact Type

\begin{tabular}{|c|c|}
\hline $\begin{array}{l}\text { Mixed Results } \\
\text { (Anderen, 2008; Birdsall, 2018; Favero } \\
\text { \& Rutherford, 2019; Gerrish, 2017; } \\
\text { Gilmour \& Lewis, 2006; Wang \& } \\
\text { Yeung, 2019) }\end{array}$ & $\begin{array}{l}\text { - Contradictions and dilemmas of } \\
\text { - } \text { decentralization/centralization } \\
\text { - Not enough time has passed to } \\
\text { - } \text { - Orgaluate impact } \\
\text { culture and resources) } \\
\text { - State dependence on performance } \\
\text { - } \text { funding } \\
\text { - Codita availability and measurement } \\
\text { - Incentives, rewards } \\
\text { - State introspection } \\
\text { - Political preferences }\end{array}$ \\
\hline
\end{tabular}




\begin{tabular}{|c|c|}
\hline & $\begin{array}{l}\text { - Difficulty using performance } \\
\text { information and performance } \\
\text { information bias } \\
\text { - More managerial autonomy and } \\
\text { authority is needed } \\
\text { - Organizational cheating or gaming }\end{array}$ \\
\hline $\begin{array}{l}\text { Symbolic and/or Weak } \\
\text { (Barnow, 2000; Bischoff \& Blaeschke, } \\
\text { 2016) }\end{array}$ & $\begin{array}{l}\text { - } \text { Imperfect performance measures } \\
\text { - } \quad \text { Proxy information } \\
\text { - } \quad \text { Sample not large enough }\end{array}$ \\
\hline $\begin{array}{l}\text { Unintended consequences } \\
\text { (Gerrish \& Spreen, 2017; Hillman, } \\
2018\end{array}$ & $\begin{array}{l}\text { - Lack of guidance about how to use } \\
\text { performance information } \\
\text { - No incentives to foster good } \\
\text { performance of underrepresented } \\
\text { populations }\end{array}$ \\
\hline $\begin{array}{l}\text { Positive } \\
\text { (Gerrish, 2016; Gilmour \& Lewis, }\end{array}$ & $\begin{array}{l}\text { - Use of performance management best } \\
\text { practices }\end{array}$ \\
\hline 2005; Heinrich, 2009; Lam \& Wang, & - Shortage of good measures \\
\hline $\begin{array}{l}\text { 2014; Pasha, 2018; Patrick \& Rollins, } \\
\text { 2015; Positer, Pasha, \& Edwards, 2013; }\end{array}$ & $\begin{array}{l}\text { - } \quad \text { Good measures } \\
\text { - Citizen perceptions }\end{array}$ \\
\hline Poister, Pasha, DeGroff, \& Royalty, & - Data manipulation \\
\hline
\end{tabular}


Impact Type

2018; Walker, Jung, \& Boyne, 2013;

Yang \& Kassekert, 2010)

\section{Factors}

- There was a PBF in place before

- Engaging proactively

- Political and public attention

- Role flexibility

- Management flexibility

- High trust between politicians and officers

- Underestimation of factors that affect performance

- Lack of capacity

No Effect

(Hillman, Tandberg, \& Fryar, 2015; Li

\& Kennedy, 2018; Rabovsky, 2012)
- Insufficient incentives

- Need more than financial incentives

- Variations in the models

- Longevity

- Higher proportion of funding is necessary

Absence of positive results has commonly occurred in performance management research (Gerrish, 2016). Notwithstanding the popularity of PMS in the public sector, PMS often do not meet the expectation that adoption and implementation will foster performance. A clear cause and effect relationship may not exist between the adoption of 
a performance management system and organizational performance; however, PMS adoption may still be valuable in that the establishment of goals will provide further clarity to the organization and its constituents. As a result, performance standards may have delivered unexpected results, not necessarily because performance was enhanced, but because of other benefits (Barnow, 2000; Hall \& Handley, 2011). For instance, the effects of using performance information have been: increasing awareness among organizations, enhancing internal department communication, and better understanding performance (Melkers, 2006).

Without unified verification that PMS fulfills its promises, we must consider unintended consequences (Andersen, 2008; Birdsall, 2018; Favero \& Rutherford, 2019; Gerrish, 2017; Gerrish \& Spreen, 2017; Hillman, 2018; Moynihan, 2008; Sohn \& Bae, 2018). Other motives (e.g., symbolic purposes) have been associated with the adoption of a PMS (Birdsall, 2019; Bischoff \& Blaeschke, 2016; Rabovsky, 2012). The shortage of a unified perception on the effectiveness of PMS might also be related to the time factor. It appears that the immediate effect of PMS is to impact the easily achievable targets; however, it becomes more difficult for the program to produce long term changes due to the inherent evolution in organizations and the time required for the PMS to adjust (Gerrish, 2016). The achievement of performance goals requires perseverance and learning and understanding of the context (Andersen, 2008; Holm, 2018; Melkers, 2006; Moynihan \& Kroll, 2016). 


\section{Limitations}

In this section, I summarized the documented limitations found in the studies included in this review. These are the common themes found in the literature on PMS included in this review:

- Time: reforms required more than six years to produce observable changes, performance management systems results based on year-to-year reports will not be able to perceive significant improvements (Andersen, 2008). In addition, even when multiple years of data are available, tracking data over time is difficult and requires sophisticated longitudinal analysis (Walker, Damanpour, \& Devece, 2011).

- Limited population: the scope of certain studies with small samples limits their ability to be conclusive or generalizable (Angiola \& Bianchi, 2015; Barnow, 2000; Birdsall, 2018; Dimitrijevska-Markoski \& French, 2019; Rivenbark, Fasiello, \& Adamo, 2019; Soss, Fording, \& Schram, 2011; Vogel \& Hattke, 2018).

- Measurement: performance management systems may not be able to show strong correspondence with positive impacts because of inaccurate measures (Barnow, 2000; Birdsall, 2019; Gilmour \& Lewis, 2005; Rabovsky, 2014a; Vogel \& Hattke, 2018; Wang \& Yeung, 2018).

- Some studies may not have accounted for all variables (Favero \& Rutherford, 2019; Gerrish, 2016; Sohn \& Bae, 2018).

- Other events may have influenced the performance measures (Hillman et al., 2015). 
- Reverse causality (Kroll, 2017): the adoption of performance management systems may have been a response to increases or decreases in performance indicators.

\section{Future Research Agenda}

The following common ideas emerged from the articles included in this review.

- Considering organizational characteristics and differences: researchers have shown that factors such as age, size, culture, and trust relations can affect adoption of a management system; a natural future venue of exploration is how a PMS can affect performance (e.g., Andersen, 2008; Angiola \& Bianchi, 2015; Birdsall, 2018).

- Utilize better measures (e.g., Barnow, 2000; Gilmour \& Lewis, 2005; Lavertu \& Moynihan, 2012a; Bischoff \& Blaeschke, 2016) and account for measures to examine how policymakers use performance information (Moynihan, 2006).

- Reverse causality - investigate if outcomes of the adoption are related to the efficacy of PMS (see Birdsall, 2019).

- Validate studies by using larger samples and more control variables (e.g., Dimitrijevska-Markoski \& French, 2019; Favero \& Rutherford, 2019; Gilmour \& Lewis, 2005).

- Public administration research and practice may benefit from using other contexts — within and beyond public administration — to understand how PMS are being designed, implemented, and managed (e.g., Gerrish, 2016; Moynihan \& Pandey, 2010; Patrick \& Rollins, 2015; Poister et al., 2018). 
- Examine other events that may influence changes in performance (e.g., Li \& Kennedy, 2018).

\section{Discussion and Conclusion}

This review of the literature on performance management systems revealed that the lessons learned rely heavily on the United States context—which crucially informs our understanding of PMS. Simultaneously, due to the lack of cross-country references, potential issues with external validity must be considered. Advanced quantitative techniques, under widely known theoretical frameworks, have been utilized in the literature. The most common theoretical framework used is New Public Management, as well as general management literature.

A limitation of this literature review is the lack of multi-disciplinary scope that stems from limiting the search key words to articles in public administration. This may have resulted in not capturing research in higher-education, economic journals and other journals in areas from which important lessons can be learned.

One objective of this chapter was to provide a conceptualization of performance management systems. I defined PMS as a three-dimensional concept: goal setting, measurement, and performance information. Each dimension is fundamental to the lifespan of a PMS. Setting goals would allow for the proper system to be in place, whereas the measurement of these goals would result in the generation of information that will be used to track effectiveness of the PMS. Because the establishment of goals is a vital component of the PMS, I expected the PMS literature to include a theme that concerns this dimension. This is not the case. Future research in the area of PMS goal establishment and measurement will be vital to further our understanding of performance 
management systems. Understanding why measurement is cited as a factor in nearly every impact type is important, and researchers should aim to isolate the factors in measurement that lead to non-positive results.

The federal government has been subject to many reform efforts that attempt to create a culture of performance management. The body of research in this review has studied these programs in depth. Higher education has also been investigated. This sector characterizes the use of performance-based funding systems. Related to providing a definition of a performance management system, I also aimed to provide a comprehensive analysis of goals that are achieved through a PMS. PMS have a common goal: to enhance performance. I identified the following keywords as goals in the literature: accountability, effectiveness, incentives, management, results, better, achieve, improvement, planning, and success.

Three recurring themes in PMS were also identified: adoption, use of performance information, and impact of the PMS. The research is tilted considerably toward studies in the use of performance information. Findings on the impact of PMS support the perception that performance management systems are not as effective as their proponents claim them to be. The use of performance information has been studied extensively. More research should focus on the impact of PMS to clarify the effectiveness of these programs. In addition, more studies should examine factors that lead to adoption. Understanding factors that lead to adoption is important. After factors are identified, then factors that yield no results can be eliminated.

In addition, understanding the factors - or combination of factors - that would lead to enhanced performance is important. Similarly, researchers should investigate why 
measurement could lead to different impacts. Determining effective approaches will enable policymakers to devise a PMS that will foster performance.

In summary, I encourage researchers in this field to explore three aspects of PMS:

organizational factors and how they affect PMS ability to foster performance, system configuration (e.g., measurement, data availability, and incentives), and factors (e.g., political, geographical, socio-economic) that are external to the organization that influence the organization's decision to adopt a PMS. 


\section{CHAPTER 3}

\section{A Theory of the Adoption and Stringency of Performance Systems: The Case of Performance-Based Funding in Higher Education}

Prior research has explained the adoption of performance systems as a result of performance pressure, ideology, and isomorphism. Isomorphism is defined as a force that makes one entity mirror an entity with similar features (DiMaggio \& Powell, 2000). However, I argue that these processes are less helpful in understanding different configurations of performance systems implemented in practice. I theorize that the stringency of performance systems is a function of learning over time through use. Systems may be initially stringent (when used to address strategic behavior and performance lapses), but stagnate later-rarely reaching the maximum stringency level. To test this theory, I examine the adoption and stringency of performance-based funding in public higher education.

\section{Adoption of Performance Systems}

The decision to adopt a new policy rarely results from one factor. Rather, it stems from a combination of factors. Prior research distinguishes between internal and external factors (McLendon et al., 2006). Internal factors are unique to the particular entity that is adopting a new policy. Examples of internal factors to an organization are its culture, communication, employee motivation, among others (Bashir \& Verma, 2019). Other factors might be external to the entity. When the adopting entity is a state, the external factors are commonly referred to as interstate factors. Understanding how each of these factors affect the decision to adopt a performance system will allow researchers to depict a more comprehensive picture of the process. 
In the past few decades, New Public Management (NPM) reforms have placed increased emphasis on performance as a means of instilling greater accountability in the public sector. This emphasis has resulted in a shift away from processes and structures to organizational results and outcomes (Kettl, 2005). Performance systems have been adopted to make organizations more business-like in an overall effort to enhance public service delivery (Walker, Boyne, \& Avellaneda, 2011).

NPM principles have inspired multiple policies at different levels of government. At the federal level, policies such as the National Performance Review (NPR) and the Government Performance and Results Act (GPRA) require that all federal agencies adopt strategic plans and performance goals and then report on their achievements. NPMinspired initiatives at the local level included customer satisfaction surveys, focus groups with users and representatives, joint decision-making between citizens and agencies, privatization, contracting, and outsourcing (Walker, Damanpour \& Deveece, 2011). Other NPM policies used performance data to inform budgetary allocations, known as performance-based budgeting (PBB) policies (Kioko, Marlow, Markin, Moody, Smith, \& Zhao, 2011). The research literature on the actual effectiveness of performance systems has produced mixed evidence. Some studies found that institutions that engage in performance management practices do perform better (Sun \& Van Ryzin, 2014; Patrick \& Rollins, 2015), while other studies detected no noticeable increase in institutional performance (Shin, 2010). Yet, undoubtedly, the overall impetus behind the adoption of performance systems is to improve the performance of public organizations (Newcomer \& Caudle, 2011; Rabovsky, 2012). In this sense, underperformance of public institutions 
should be viewed as a precursor to the adoption of a performance system. This rationale led to the following hypothesis:

\section{$\mathbf{H}_{1}$ : Achievement deficits are associated with the adoption of a performance} system.

Performance systems in the public sector are adopted through the enactment of specific laws or other formal legal requirements. In the United States, Republicans are consistently associated with conservative ideology, championing smaller and less active government, noninterventionist economic policies, and unrestricted commercial markets. In this sense, legislatures dominated by members of the Republican Party are more likely to adopt policies that are indirectly skeptical of state bureaucracy. By contrast, Democrats are associated with more liberal ideology that advocates for government programs to alleviate social disparities. Thus, legislatures dominated by members of the Democratic Party tend to have higher levels of state spending on public education and welfare (Treier \& Hillygus, 2009; Lupton, Myers, \& Thornton, 2017; McLendon et al., 2006). In general, conservative policymakers (i.e., Republicans) are cautious about expanding the role of government, whereas liberals (i.e., Democrats) hesitate to rely on market-based policies (Butler, Volden, Dunes, \& Shor, 2017). Therefore, performance systems - NPM-inspired policies that emphasize market principles - are likely to be popular among conservative policy-makers (Lapenta, Fattore, \& Dubois 2012).

For the purposes of this research, I will use the classical definition of political ideology which is an orientation to political parties or interests (Martin, 2015). Prior research has produced extensive evidence on the role of ideology on policy outcomes. Examples include health insurance coverage (Cummins, 2011), biotechnology (Harris, 
2015), and state lotteries (Jensen, 2003). In state politics, the ideological affiliation of the Governor often accurately predicts the types of policies adopted in that state. A study by Julnes and Mixcoatl (2006) demonstrated how state governors were the most influential political figures in the state due to their authority over budget allocations, selection of key employees, and setting of policy and program priorities, a finding that is consistent with previous studies (King, Zeckhauser, \& Kim, 2002). Thus, the second hypothesis of the present study tests the effect of another internal factor: the ideology of state-elected public officials. Given that NPM emphasizes enhanced performance by injecting market mechanisms into public service delivery, and that conservative policymakers favor small government that avoids intervening in the market, we expect that legislatures dominated by conservative elected officials are more likely to adopt performance management systems.

$\mathbf{H}_{2}$ : A conservative ideology is associated with the adoption of performance systems.

In addition to internal factors, policy adoption might be determined by external factors created by geographical policy diffusion. Policy diffusion refers to the situation, where "one government's policy choices [are] being influenced by the choices of other governments" (Shipan \& Volden, 2012, p. 789). In the classic view of policy diffusion, at the state level, policy adoption is influenced by geographically bordering states that previously adopted that policy (Walker, 1969). The concept was further developed by Berry and Berry (1990), who defined policy adoption resulting from regional diffusion (i.e., the influence of next-door or geographic neighbors) as horizontal diffusion.

The policy diffusion theory has been widely used in different contexts. For instance, the likelihood of adopting antismoking policies has increased as a result of 
neighboring states passing such policies (Shipan \& Volden, 2006). Other policy areas where the geographical diffusion pattern has been studied include state lottery policies (Berry \& Berry, 1990; Mooney, 2001), electronic-government (i.e., "the government's use of technology to enhance the access and delivery of government and services to citizens, business partners, employees, other agencies and entities"; Layne \& Lee, 2001, p. 123) (Norris \& Moon, 2005; Lee, Chang, \& Berry, 2011), and climate change (Matisoff, 2008). In the context of education reforms, external factors (e.g., regional diffusion) have proven to be positively associated with policy adoption (Mintrom \& Vergari, 1998).

The prevalent diffusion of performance systems is considered to be among the most noteworthy advances in public administration in the 20 years since the 1968 Minnowbrook Conference (Monhiyan, Fernandez, Kim, LeRoux, Piotrowski, Wright, \& Yang, 2011). Berry (1994) found a positive relationship between the adoption of strategic planning for states when neighboring states adopted such a policy. Diffusion of performance innovation has been shown to be positively correlated with the transfer of public managers (Yi, Berry, \& Chen, 2019). More recently, however, research in the context of higher education has revealed a negative relationship between adoption in a state when neighboring states have installed the policy (Li, 2017).

This chapter's third hypothesis draws from horizontal diffusion theory (Walker, 1969; Berry \& Berry, 1990). The logic behind the horizontal diffusion theory is that public policies spread among states where a regional leader adopts a given policy first and neighboring states within the geographic region follow. 
$\mathbf{H}_{3}$ : Adoption of a performance system is more likely if there is a prior adopter in the proximity.

In summary, internal and external factors affect the decision to adopt a new policy (McLendon et al., 2006). The present study sought to test two internal factors: performance deficiency and political ideology. Specifically, I expected that lapses in performance, and prevalence of conservative political ideology among elected officials, would be positively associated with the adoption of a performance system. The present study also tested the effect of one external factor-geographical diffusion, which assumes that a state will be more likely to adopt a policy if neighboring states have previously adopted a similar policy.

\section{System Stringency of Performance Systems}

After a PMS is adopted, what factors affect the stringency of the performance systems? A performance system establishes performance goals for the program or agency (Moynihan, 2006). Therefore, the factors affecting the stringency of the performance criteria (i.e., the system configuration) are important. The level of stringency of a performance system will impact how performance information is framed, which will then impact the success of the entire system (Battaglio \& Hall, 2018).

I drew from principal-agent theory to formulate expectations about the degree of stringency of a performance system. In general, the theory describes a contractual relationship between a principal and an agent, where the principal establishes specific terms and conditions about agent behavior (Perrow, 1986). In the case of performance systems in the public sector, the principal is the politically conservative elected official who adopts an NPM-inspired policy, whereas the agent is the government entity being 
subject to the performance system. Performance management guarantees the recovery of the control over policy-making for elected officials (Moynihan, 2008).

Researchers have applied the principal-agent model in various contexts, including examination of a job-training program in the United States (Courty \& Marshcke, 2003), evaluation of the pharmaceutical-patient relationship (Chressanthis, Dahan, \& Fandl, 2015), and assessment of e-government innovations (Heeks \& Santos, 2009), to name a few. This theoretical framework has also been used extensively in performance literature: Tandberg and Hillman (2014) utilized the model to explain the impact of performancebased funding in higher education. Ferris (1992) analyzed educational performance; Selviaridis and Norrman (2015) explored its effect on performance-based contracts. Cavalluzzo and Ittner (2004) studied results-oriented performance measurements in the federal government.

Principal-agent theory is multifaceted. The one pertinent to performance systems in public higher education relates to information asymmetry. The principal's access to information is limited and the actions of the agent must be closely monitored, which is costly and subject to time constraints (Jacobides \& Croson, 2001). Given the costs associated with monitoring agent behavior, the states rely on few performance indicators to measure agent performance without capturing true output (Nisar, 2015). The principal can change the measurement system as new information becomes available after a measure has been enacted (Courty \& Marshchke, 2003).

In other words, the principal might make the system more stringent over time. Prior research shows that the level of stringency of a performance system increases, in particular, when the principal realizes that the agent is "gaming the system". Gaming is a 
practice that refers to manipulative actions that aim create the appearance that outcomes have been achieved" (Legge, 2016). This practice has been recognized as a concern in a performance system (Durant, 2009). Gaming occurs after the agent discovers ways to manipulate the system (Heinrich \& Marschke, 2010). Therefore, time is a key aspect of the principal's reaction to performance of the agent.

My hypothesis was that stringency is a function of experience with the system rather than something static that is predefined in the adoption phase. As time passes, both principal and agent learn more about the system. The agent discovers ways to game the rules; the principal, in turn, responds by tightening the monitoring standard. Thus, the expectation was that the stringency of performance systems will increase over time due to learning effects.

$\mathbf{H}_{4}$ : The stringency of a performance system increases with the duration of use. Although the principal could continuously adjust the system's stringency, will this process last indefinitely? The diffusion of a policy adoption follows an S-curve, which is characterized by a slow beginning, rapid expansion, and tapering off (Glick \& Hayes, 1991). I argue that the adjustment does not continue forever and, in fact, reaches a climax. For elected officials and public managers, the performance systems have "symbolic benefits": performance systems allow officials and managers to demonstrateto a diverse group of constituencies - that government is being managed in a "rational, efficient, and results-oriented way and that bureaucrats are being held accountable for their performance” (Moynihan, 2005, p. 227). Similarly, Feldman, and March (1981, p. 182) discussed symbolic benefits of performance information for the decision-makers: “information use symbolizes a commitment to rational choice" (p. 182). In other words, 
the acquisition of performance data gives legitimacy to the decision-making process because a conscious effort to make the right decision occurs, regardless of whether or not the data are actually being used.

Based on the literature on symbolic effects of policies, I anticipated that stringency of performance systems will eventually stagnate. The are many plausible reasons for this to happen, for instance, the policy may have been poorly designed from its inception. Another reason is that the policy may be highly contested and loses its momentum once the contestations disappear. For the purposes of this research, the reason I will assume is that the reasons stagnation takes place is that politicians stop directing efforts to reconfigure the system and simply choose to retain it to demonstrate that the government is acting to address the problem. Another explanation is that the issue at hand might become less salient among the citizenry. This could occur because the citizens feel satisfied and pressure to resolve the issue diminishes, or because there is a competing issue to which they must direct their attention. Thus, most systems never reach the maximum stringency level. I expected that the relationship between years of use and system stringency would be nonlinear and eventually reach a saturation point. To reach a tipping point means to reach a point where people involved see the need to reframe the issue or take another course (Gladwell, 2000). Such point occurs when policy initiators feel that they have satisfied the requirement to act or turn to other, more pressing issues, and let the system stagnate.

H5: The stringency of performance systems reaches a saturation point. In sum, I anticipated that the stringency level would change over time. As principal-agent theory suggests, it is likely that stringency will increase with the years of 
use. The expectation was that the principal would tighten the performance standard to counter the possible gaming behavior of the agent. I also predicted that the adjustments would reach a tipping point, based on the symbolic benefits rationale.

\section{Data and Methods}

\section{Research Setting}

The above hypotheses have been tested in the context of performance-based funding in higher education. In the United States, there are more than 700 public fouryear colleges or universities serving over eight million students (U.S. Department of Education, 2018). The significant impact of universities on the economic well-being of the individual and on the overall evolution of society has been discussed extensively (Gooden, 2014; Crow \& Shangraw, 2016). Pittsburgh, Seattle, and Boston are examples of communities where institutions of higher education have played a pivotal role in economic development through invention and commercialization of new technologies and partnerships between universities and local governments (Gordon, 2010).

Many factors influence adoption of new funding mechanisms in universities. These include: globalization, movements to reinvent government, competing financial objectives in state budgets, $\mathrm{K}-12$ reforms that intensified focus on the education sector, changes in state political leadership, and failure to deliver under the previous funding model systems (McLendon et al., 2006). The output model relies on business value, such as return on investment, efficiency, and competitiveness (Todd \& Anderson, 2016), which became inevitable.

The quantitative analysis in the present study draws on data from all 4-year, public, doctoral-degree granting universities in the United States that are classified as 
Carnegie-Highest-Research activity (R1). The Carnegie Classification system has been the leading framework for acknowledging, describing, and labeling institutional diversity in U.S. higher education for more than 45 years (Shulman, 2001). R1 institutions are universities that graduate at least 20 doctoral students and have a minimum of $\$ 5$ million in research expenditures. Public R1 institutions were selected to ensure that the institutions shared similar characteristics and mission, which helped me avoid issues related to sample bias. The sample consists of data from 40 states with 82 institutions amassed from 2000 to 2015. Given that performance-based funding was adopted at the state level, the unit of analysis is the state. Figure 5 presents the states with a performance-based funding (PBF) program as of 2015, along with each state's year of adoption. The data for the analysis came from different sources, including the Integrated Postsecondary Education Data System, National Conference of State Legislatures, and the State Higher Education Finance, among others. 
Figure 5. States with PBF as of 2015 by Year of Adoption

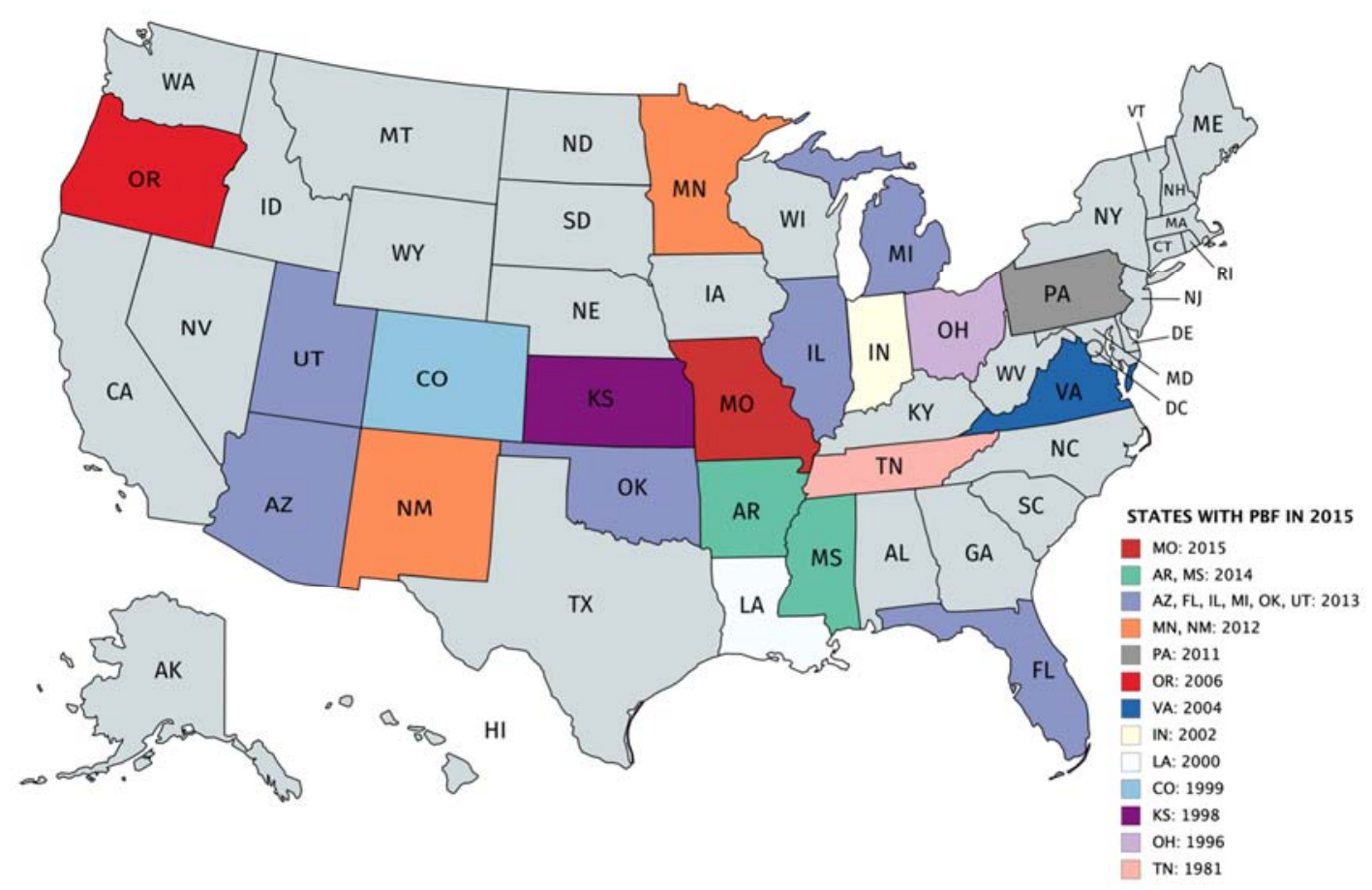

\section{Measuring Adoption and Stringency}

The dependent variable in the adoption model is dichotomous: the variable assumes a value of 1 for the years when the state had a PBF in place and as 0 otherwise. To operationalize the stringency of the adopted PBF model in a state, I developed an additive index, called the Public Funding Uncertainty Index (PFUI). The index consists of five dimensions. I reviewed all performance-based systems currently installed to arrive at the dimensions. Each dimension is discussed in detail below and described in Table 7. 
Table 7. PFUI: Performance-based funding Dimensions

\begin{tabular}{|c|c|c|c|}
\hline Dimension & Definition & Sub-Categories & States (as of 2015) \\
\hline \multirow{3}{*}{ I. Benchmarking } & \multirow{3}{*}{$\begin{array}{l}\text { refers to the comparisons } \\
\text { that the PBF relies on to } \\
\text { gauge the eligibility of an } \\
\text { institution for funding }\end{array}$} & $\begin{array}{l}\text { a. basic: compares institutions } \\
\text { over time and only considers their } \\
\text { own past performance }\end{array}$ & $\begin{array}{l}\text { Arizona, Colorado, Illinois, Indiana, } \\
\text { Louisiana, Michigan, Minnesota, } \\
\text { Mississippi, New Mexico, Ohio, } \\
\text { Oregon, Tennessee, Utah, and } \\
\text { Virginia }\end{array}$ \\
\hline & & $\begin{array}{l}\text { b. industry-standard: performance } \\
\text { goals are based on what are } \\
\text { considered possible outcomes for } \\
\text { institutions based on certain } \\
\text { criteria }\end{array}$ & Missouri and Pennsylvania \\
\hline & & $\begin{array}{l}\text { c. dynamic: includes other factors } \\
\text { in addition to the institution's } \\
\text { own performance }\end{array}$ & Arkansas, Florida, and Oklahoma \\
\hline \multirow[t]{3}{*}{$\begin{array}{l}\text { II. Funding } \\
\text { Methodology }\end{array}$} & \multirow[t]{3}{*}{$\begin{array}{l}\text { captures the methodology } \\
\text { used to allocate dollars for } \\
\text { an institution's budget on a } \\
\text { performance basis }\end{array}$} & a. fixed percentage & $\begin{array}{l}\text { Arkansas, Arizona, Colorado, } \\
\text { Florida, Illinois, Indiana, Louisiana, } \\
\text { Michigan, Minnesota, Missouri, } \\
\text { Mississippi, New Mexico, Ohio, } \\
\text { Oregon, Pennsylvania, Tennessee, } \\
\text { and Virginia }\end{array}$ \\
\hline & & b. lump sum & Utah \\
\hline & & c. formula & Oklahoma \\
\hline
\end{tabular}




\begin{tabular}{|c|c|c|c|}
\hline Dimension & Definition & Sub-Categories & States (as of 2015) \\
\hline \multirow{3}{*}{ III. Impact to Base } & \multirow{3}{*}{$\begin{array}{l}\text { examines the impact to the } \\
\text { institution's base budget }\end{array}$} & $\begin{array}{l}\text { a. incremental to the institution's } \\
\text { base budget but does not remain } \\
\text { in the base }\end{array}$ & $\begin{array}{l}\text { Arizona, Colorado, Oregon, and } \\
\text { Utah. }\end{array}$ \\
\hline & & $\begin{array}{l}\text { b. incremental and PBF funds } \\
\text { become part of the base }\end{array}$ & $\begin{array}{l}\text { Arkansas, Florida, Illinois, Indiana, } \\
\text { Louisiana, Michigan, Minnesota, } \\
\text { Missouri, Mississippi. New Mexico, } \\
\text { Ohio, Oklahoma, Pennsylvania, and } \\
\text { Tennessee }\end{array}$ \\
\hline & & c. non-dollar based & Virginia \\
\hline \multirow[b]{2}{*}{ IV. Complexity } & \multirow{2}{*}{$\begin{array}{l}\text { based on the total number } \\
\text { of key performance } \\
\text { indicators (KPIs). KPIs are } \\
\text { used to measure the } \\
\text { university's performance }\end{array}$} & a. five KPIs or less & $\begin{array}{l}\text { Arizona, Colorado, Missouri, New } \\
\text { Mexico, Ohio, and Oregon }\end{array}$ \\
\hline & & b. more than five KPIs & $\begin{array}{l}\text { Florida, Illinois, Indiana, Louisiana, } \\
\text { Michigan, Minnesota, Mississippi, } \\
\text { Oklahoma, Pennsylvania, } \\
\text { Tennessee, Utah, and Virginia }\end{array}$ \\
\hline \multirow[b]{2}{*}{$\begin{array}{l}\text { V. Penalty for } \\
\text { Underperformance }\end{array}$} & \multirow[b]{2}{*}{$\begin{array}{l}\text { refers to whether or not } \\
\text { institutions are punished if } \\
\text { they do not meet the } \\
\text { performance requirements, } \\
\text { or if they perform } \\
\text { significantly worse than as } \\
\text { compared to other } \\
\text { institutions }\end{array}$} & a. penalty & Florida \\
\hline & & b. no penalty & $\begin{array}{l}\text { Arkansas, Arizona, Colorado, } \\
\text { Illinois, Indiana, Louisiana, } \\
\text { Michigan. Minnesota, Missouri, } \\
\text { Mississippi. New Mexico, Ohio, } \\
\text { Oklahoma, Oregon, Pennsylvania, } \\
\text { Tennessee, Utah, and Virginia }\end{array}$ \\
\hline
\end{tabular}


The first dimension refers to the mechanism of benchmarking. PBF relies on comparisons to gauge the eligibility of an institution for funding. There are various ways to establish benchmarks, and the choice of a benchmarking mechanism affects the level of budget uncertainty that PBF creates for institutions in each state's higher education system. Some PBF models are based on comparison over time and only consider the institution's past performance. In this case, the degree of uncertainty is low because the institution can predict the level of growth it must achieve in the following year to surpass its performance in the current year. This is the case for most states. For example, in 2015, out of 20 states that had a PBF model installed, 15 followed this benchmarking mechanism. These states were: Arizona, Illinois, Indiana, Kansas, Louisiana, Massachusetts, Michigan, Minnesota, Mississippi, New Mexico, Ohio, Oregon, Tennessee, Utah, and Virginia.

A higher level of uncertainty is associated with performance measures that tie performance of one institution to factors other than its own performance. These states are considered to have a dynamic benchmarking mechanism. In 2015, Florida, Arkansas, Missouri, Oklahoma, and Pennsylvania utilized this approach.

PBF models in Missouri and Pennsylvania introduced a benchmarking system that follows "industry standards": performance goals are based on possible outcomes for the institutions based on certain criteria. Missouri's performance measures are evaluated based on each institution's improvement on performance from the previous year. However, this system also has a component of "sustained excellence," comparing performance to an established benchmark rather than improvement over the previous year (Department of Higher Education and Workforce Development, 2016). Pennsylvania's 
system measures university performance based on institution-specific goals, but also against external comparisons or expectations that are based on national studies (Mansfield University, 2012). The industry-standard benchmarking mechanism introduces an increased level of budget uncertainty, because institutions are not only held to their own performance, but also to the performance of a much larger population of institutions.

The Arkansas PBF model evaluates performance based on the number of bachelor's degrees awarded. The current year's total bachelor's degrees awarded is compared against the institution's own growth from the base-year. This PBF model awards compensatory points for percentage of undergraduate students receiving Pell Grants (State of Arkansas, 2017). Thus, institutions with more students eligible for Pell Grants have an advantage. I consider this to be a source of increased uncertainty, given that the number of students with Pell Grants is beyond an institution's control.

The pre-established benchmark provides an added level of uncertainty because institutions may be set out to be penalized if their results are below this goal. If the preestablished benchmark is unknown or released late, institutions may also have a hard time achieving this goal. Oklahoma's performance funding formula incorporates an equity component. The goal is to help institutions that have historically fallen behind their peers. Therefore, institutions are based on their performance, but they are also compared to their peers within the state to ensure similar institutions reach the same performance levels.

For example, according to the Florida Board of Governors website Florida's PBF measures performance based on each institution's individual improvement, but also based on benchmarks for excellence established by Florida's governing body—based on 
historical performance of the state institutions. States that utilize this dynamic approach to PBF, whereby the funding level is based on a combination of factors rather than solely on the institution's own performance, have introduced more uncertainty into their higher education systems.

The benchmarking mechanism that ties performance to other institutions within the same system contains a higher uncertainty because institutions within a system may be very distinct from one another. Some institutions may have a competitive advantage to perform better due to factors other than the performance itself. The industry-standard benchmarking system, however, does compare institutions that meet certain criteria, which makes the comparisons fair and equitable.

To gauge the level of uncertainty created using different benchmarking systems, a variable with three realizations was used. The benchmarking system is coded as 1 , when performance was measured against an institution's own performance in the past, coded as 2 when performance was based on an "industry-standard," or coded as 3 when the PBF mechanism used a dynamic benchmark tied to performance of other institutions in the system. A value of 0 was used to denote the absence of PBF implementation.

The amount of funding allocated through PBF differs across states, as well as the mechanism used. This affects the ability of institutions to predict their future financial streams. The second PFUI dimension captures the methodology used to allocate dollars on a performance basis. The present research revealed that funds are typically allocated through a percentage of total budget. Indiana, for example, allocates only $5 \%$ of the total budget based on performance, Oregon allocates $1 \%$, Illinois allocates $0.5 \%$, and Michigan allocates $11 \%$, while Tennessee allocates $100 \%$ of the funds to state 
universities based on performance. Other states do not allocate funds based on a fixed percentage — rather, they allocate a lump sum amount. Utah's PBF model, initiated in 2013, began as a $\$ 1$ million pilot bonus - a one-time, performance-based — funding program. This amount was later raised to \$1.5 million in 2014 and \$5 million in 2015 (Utah Foundation, 2014).

To achieve equity between and among all state institutions, Oklahoma uses a "Weight of Performance Measure Multipliers," where each performance indicator is assigned a weight. These indicators can vary from year-to-year for institutions that are below one standard deviation of their peers (Oklahoma State Regents for Higher Education, 2018). Massachusetts PBF program also utilizes a complex formula of metrics and weights (Massachusetts Department of Higher Education, 2015). The PBF in Kansas uses a formula to determine how much new funding each institution is entitled to, based on their progress toward reaching performance goals. Institutions may be entitled to $100 \%, 90 \%, 75 \%$, or no new funding, based on the Board's assessment of the institution's effort toward meeting their goal (Kansas Board of Regents, 2017). These formulas introduce a higher level of uncertainty because institutions may not have access to all the information required to devise the formula.

The lump sum amount is the approach that creates the least degree of uncertainty because institutions know in advance the total dollar amount that could potentially be awarded and could, therefore, decide if it is worthwhile to use time and resources to emphasize performance. The percentage approach increases the uncertainty in the system but still allows institutions to anticipate what amount from their budget will be distributed based on performance. Therefore, it is easy to anticipate what level of funding is at stake. 
The percentage, however, varies depending on the total budget base amount, which is unknown from year-to-year. Lastly, the formula approach provides the most uncertainty. Because there are multiple factors to consider, anticipating the amount of funds allocated based on performance becomes a difficult task.

The second PFUI dimension is coded as 1 if the funds from the PBF are a lump sum amount, coded as 2 if they are based on a percentage, and coded as 3 if they are based on a formula.

The third PFUI dimension captures the impact to the base budget of the institution. The extent to which PBF impacts an institution's budget varies with regard to the institution's base budget. In some states, performance funds are incremental (i.e., in addition to each institution's base budget in subsequent years), but do not remain in the institution's base budget. This is the case for Arizona, Oregon, and Utah. Another possibility is for funds allocated through PBF to be an increase to the new budget year, and to become part of the permanent base budget for the following year, which was the case exhibited most often among the various institutions. Fourteen out of the 20 states had a PBF mechanism in 2015.

Virginia's PBF model is a unique case because the reward for the state's performance is not presented in the form of dollars, but rather in the form of administrative autonomy. Financial benefits are provided on a case-by-case basis (Office of the Washington State Auditor, 2014).

The third PFUI dimension is coded as 0 when there is no PBF; coded as 1 if the model entails one-time funds that are not added to the institution's base budget the following year, and coded as 2 if the funds are incremental and added to the base 
budget. Additionally, the third PFUI dimension was codes as 1.5 for cases in which PBF was a combination of codes 1 and 2 (50-50 distribution) or for cases such as Virginia.

To tackle the level of complexity of the PBF model, a fourth dimension was included — based on the total number of performance indicators. Each state typically establishes its own set of indicators to determine institutions' eligibility for performance funding. Thirteen states, including Florida, Louisiana, Michigan, and Missouri, evaluate more than five indicators, whereas the other seven states examine less than five indicators. These states include Arizona, Ohio, and Massachusetts. Given that a larger number of indicators requires more evaluation and increased effort to assess, systems with a larger number of indictors are considered more stringent. In terms of coding, a value of 1 was assigned to PBF models with up to 5 indicators, and a value of 2 was assigned to models consisting of more than 5 indicators. As before, a value of 0 denotes the lack of PBF in the state.

The last PFUI dimension captures the extent to which states may impose penalties for underperformance. Institutions might be punished if they do not meet the performance requirements, or if they are the lowest performers in the ranking system as compared to other institutions. For example, in the state of Florida, institutions are evaluated based on excellence or improvement for each metric. When an institution does not meet the required number of points and is one of the three lowest performers within the state university system, it is not entitled to the state performance funds, and must therefore contribute funds from its own base budget to make up a pool of performance funds to be distributed between all universities. A dichotomous variable was used to indicate whether or not the state PBF model requires institutions to make funds available to contribute to 
the pool, based on the rules of the model. Institutions were coded as 1 if they are not required to contribute any funds at risk due to underperformance and coded as 2 if they are subject to a penalty for underperformance.

The analysis in the present study utilizes the additive index as the dependent variable in the stringency model. The additive index for the year 2015 reveals that Florida was the state with the highest stringency level of 8 , whereas Arizona and Oregon had the lowest stringency level score of 4.5. This differs from the year 2000, where South Carolina had the most stringent PBF with a score of 7, and Arkansas, Colorado, and New Jersey had the least stringent system, with scores of 3.5 each. In the year 2015, excluding states with no PBF in place (which would score 0 on the index), the mode was 6.5 (for Illinois, Louisiana, Michigan, Minnesota, Missouri, Mississippi, and Tennessee). The mode in 2000 was 3.5 (for Arkansas, Colorado, and New Jersey). This suggests that stringency increased over time. In addition, 30 states scored 0 in the year 2000, while this number decreased to 19 in the year 2015.

The Cronbach's Alpha for the index was 0.9465 . The high alpha suggests the dimensions are measuring the same underlying concept and supports the creation of an additive index. For standardization purposes, the values from the variables for Benchmarking and Percentage were divided by 2 to have the same multiplier (i.e., the same range for minimum and maximum values). An index was also created using the factor analysis principal component technique. The findings yielded the same significant results using the additive index and when using the principal component analysis. Table 8 presents the information from the principal component analysis. 
Table 8. Principal Component Analysis

\begin{tabular}{|c|c|c|c|}
\hline Variable Nam & Variable Definition & $\begin{array}{c}\text { Factor } \\
\text { Loading }\end{array}$ & $\begin{array}{l}\text { Uniqueness } \\
\text { Score }\end{array}$ \\
\hline \multicolumn{2}{|c|}{$\begin{array}{l}\text { BenchmarkingParameters used to measure the performance of the } \\
\text { institutions. } \\
0=\text { no PBF } \\
1=\text { when performance is measured against } \\
\text { institution's own performance in the past } \\
2=\text { when performance is based on an "industry } \\
\text { standard" } \\
3=\text { when performance uses a dynamic benchmark }\end{array}$} & 0.9457 & 0.1057 \\
\hline Percentage & $\begin{array}{l}\text { Methodology used to allocate dollars associated } \\
\text { with the performance system. } \\
0=\text { no PBF } \\
1=\text { if the funds from the PBF are a lump sum } \\
\text { amount; } \\
2=\text { if they are based on a percentage } \\
3=\text { if they are based on a formula }\end{array}$ & 0.9635 & 0.0716 \\
\hline \multicolumn{2}{|c|}{$\begin{array}{l}\text { Impact to base Impact of the funding to the base budget of the } \\
\text { institution. } \\
0=\text { no PBF } \\
1=\text { if the model entails one-time funds that are not } \\
\text { added to the institution's base budget the following } \\
\text { year; } \\
1.5=\text { when there's a combination of both }(50-50 \\
\text { distribution) } \\
2=\text { if the funds are incremental and added to the } \\
\text { base }\end{array}$} & 0.9767 & 0.0461 \\
\hline Complexity & $\begin{array}{l}\text { Captures the number of key performance indicators } \\
\text { used by the system. } \\
0=\text { no PBF } \\
1=\text { if the PBF model entails from } 1 \text { to } 5 \text { indicators } \\
2=\text { if the models consist of more than } 5 \text { indicators }\end{array}$ & 0.9093 & 0.1732 \\
\hline Penalty & $\begin{array}{l}\text { The extent to which states may impose penalties for } \\
\text { underperformance. } \\
0=\text { no PBF } \\
1=\text { if they are not required to put up any funds at risk } \\
\text { due to underperformance } \\
2=\text { if they do have to face a penalty for } \\
\text { underperformance }\end{array}$ & 0.9520 & 0.0937 \\
\hline
\end{tabular}

Eigen Value: 4.5096 


\begin{tabular}{|c|c|c|c|}
\hline Variable Name & Variable Definition & $\begin{array}{c}\text { Factor } \\
\text { Loading }\end{array}$ & $\begin{array}{c}\text { Uniqueness } \\
\text { Score }\end{array}$ \\
\hline
\end{tabular}

The Principal component technique takes into account the information offered by many observations by utilizing a more restricted group of assembled dimensions which become essentially replacements for the variables (Tabachnick \& Fidell, 2001). The reduced number of variables allows for clearer comparisons across samples. It also enhances the consequent statistical analyses and, when using multiple regressions, where there are many explanatory variables, it helps avoid the problem of exploitation of associations by chance (Yang \& Miller, 2008).

Yang and Miller (2008) explained that a shortcoming of using principal component analysis is that it was not invariant as it related to scaling decisions. They explained that the higher the variance of one variable relative to others, the more influence it would have on the direction of the principal component. Because the "percentage" variable is measured differently, and in order to avoid any issues due to measurement, the variables were standardized to create the index using the principal component factor. Because the variables were standardized, principal components with eigenvalues greater than 1.0 were retained (Yang \& Miller, 2008). Therefore, the results from the principal component analysis suggest a solution of one principal component. By using a promax rotation, the factor loadings were obtained. The results suggest the creation of an index based on all five dimensions with high loadings (all greater than $0.90)$. 


\section{Independent Variables}

To determine the number of years the PBF was present, each state's performance system was analyzed for the period of 2000-2015 and coded based on year of adoption and the documents reviewed. To test Hypothesis 1, a proxy for the state's performance system was required. Initially, I planned to use the Measuring Up score. This was an effort from the federal government to create a National Report Card for higher education institutions. However, the score was not available for all the years examined in this dissertation, and thus it was not a viable option. The best indicator found to capture the performance of the state higher education system was the average ranking as measured by the U.S. News Survey report. The survey is administered to top academics (presidents, provosts, and deans of admissions). It seeks to explore the aspects of their peer institutions based on a scale from 1 to 5. During the most recent year (i.e., 2015) this study examined, the top performing state, as measured by U.S. News, was Minnesotawith a score of 3.6. The lowest performing was Mississippi with a score of 2.3. The average performance score was 2.81 , whereas the median and mode were both 2.8 .

To operationalize the dominant ideology in the state legislature, I used the political party affiliation of the governor and the percentage of Republicans in the legislature (Bourdeaux \& Chikoto, 2008; Lavertu \& Moynihan, 2012a). The assumption was that Republicans are the conservative party, while Democrats are the more liberal party. To gauge whether the adoption of PBF was a result of policy diffusion from neighboring states (Hypothesis 3), I included a variable in the model that was derived using the ratio of neighboring states with PBF over the total number of neighboring states. The expectation was that the higher the proportion of surrounding states that have 
adopted a PBF, the higher the probability of the state in question moving to adopt the program. Other studies have used a similar approach (Shipan \& Volden, 2006; Li, 2017; Mintrom \& Vergari, 1998).

To test Hypothesis 5, I included a squared term for the years the performance system was in effect. I argue that the relationship between stringency and the number of years the PBF was in place is nonlinear. The expectation was that the longer the PBF was in place, the less stringent the system would become after it reaches a tipping point.

This analysis also included a number of control variables. I used the total number of legislators to assess the complexity to reach a decision. The larger the number of people involved in decision making, the more complex the process was, and therefore the more stringent the PBF system became. To account for the state's reliance on personal income and sales tax, a ration of these two variables over the total revenue was included. More diversified revenue states with a higher proportion of income tax revenue or sales tax revenue would be less inclined to have a PBF.

Another control variable that was included was the proportion of higher education total expenses over the states' total expenses. The higher the proportion of expenses that were directed toward higher education, the less likely the state was to adopt. Similarly, the higher the proportion of expenses directed toward higher education, the more stringent the systems would be. Finally, the census region and unemployment rates were included. Regression results are shown, including the yearly "fixed effects," to account for unobserved factors that are relatively stable over time, such as recessions and other economic shocks. Appendix A has information regarding the measures and their sources. The descriptive statistics for all variables are listed in Table 9. 
Table 9. Descriptive Statistics, Adoption and Stringency Models

\begin{tabular}{|c|c|c|c|c|c|c|c|c|c|c|c|c|c|c|c|c|c|c|c|c|}
\hline Variable & Mean & SD & Min & Max & Obs & 1 & 2 & 3 & 4 & 5 & 6 & 7 & 8 & 9 & 10 & 11 & 12 & 13 & 15 & 16 \\
\hline PFUI & 1.51 & 2.68 & 0.00 & 8.67 & 624 & 1.00 & & & & & & & & & & & & & & \\
\hline PBF & 0.28 & 0.45 & 0.00 & 1.00 & 624 & 0.91 & 1.00 & & & & & & & & & & & & & \\
\hline US News & 2.93 & 0.32 & 2.20 & 3.90 & 608 & -0.11 & -0.17 & 1.00 & & & & & & & & & & & & \\
\hline $\begin{array}{l}\% \text { of Neighboring } \\
\text { states with } \\
\text { PBF/Total } \\
\text { Neighboring States }\end{array}$ & 0.24 & 0.21 & 0.00 & 1.00 & 624 & -0.01 & -0.06 & -0.20 & 1.00 & & & & & & & & & & & \\
\hline $\begin{array}{l}\text { Republican } \\
\text { Legislature }\end{array}$ & 0.48 & 0.15 & 0.11 & 0.83 & 608 & 0.35 & 0.31 & 0.04 & 0.21 & 1.00 & & & & & & & & & & \\
\hline $\begin{array}{l}\text { Republican } \\
\text { Governor }\end{array}$ & 0.51 & 0.50 & 0.00 & 1.00 & 624 & 0.07 & 0.09 & -0.12 & 0.05 & 0.28 & 1.00 & & & & & & & & & \\
\hline Yrs. PBF Present & 2.25 & 5.36 & 0.00 & 34.00 & 624 & 0.61 & 0.68 & -0.27 & -0.02 & 0.26 & 0.03 & 1.00 & & & & & & & & \\
\hline $\begin{array}{l}\text { Total Number of } \\
\text { Legislators }\end{array}$ & 148 & 44.00 & 49.00 & 253.00 & 624 & 0.00 & -0.06 & 0.04 & 0.00 & 0.01 & 0.04 & -0.09 & 1.00 & & & & & & & \\
\hline $\begin{array}{l}\text { Unemployment } \\
\text { Rate }\end{array}$ & 6.09 & 1.93 & 2.20 & 13.90 & 608 & -.01 & -0.01 & -0.18 & 0.05 & -0.08 & -0.06 & 0.05 & 0.08 & 1.00 & & & & & & \\
\hline $\begin{array}{l}\text { Personal } \\
\text { Income/Total } \\
\text { Revenue }\end{array}$ & 0.41 & 0.18 & 0.00 & 0.87 & 622 & 0.07 & 0.05 & 0.26 & -0.08 & -0.09 & -0.16 & -0.20 & 0.02 & -0.04 & 1.00 & & & & & \\
\hline $\begin{array}{l}\text { Sales Tax } \\
\text { Revenue/Total } \\
\text { Revenue }\end{array}$ & 0.37 & 0.31 & 0.00 & 2.36 & 622 & 0.19 & 0.22 & -0.28 & 0.00 & 0.17 & 0.12 & 0.66 & -0.03 & 0.02 & -0.59 & 1.00 & & & & \\
\hline $\begin{array}{l}\text { Higher Education } \\
\text { Total Expenses }\end{array}$ & 0.13 & 0.04 & 0.03 & 0.28 & 624 & -0.11 & -0.10 & -0.20 & 0.34 & 0.29 & 0.18 & -0.06 & -0.15 & -0.03 & -0.16 & 0.17 & 1.00 & & & \\
\hline West & 0.21 & 0.40 & 0.00 & 1.00 & 624 & -0.01 & 0.03 & 0.12 & -0.09 & -0.7 & -0.07 & -0.06 & -0.50 & 0.07 & 0.04 & -0.04 & -0.11 & 1.00 & & \\
\hline Midwest & 0.26 & 0.44 & 0.00 & 1.00 & 624 & 0.16 & 0.15 & 0.27 & 0.01 & 0.27 & 0.01 & 0.08 & 0.03 & -0.09 & 0.18 & -0.10 & 0.15 & $-0.30 \quad 1.00$ & & \\
\hline Northeast & 0.13 & 0.33 & 0.00 & 1.00 & 624 & -0.12 & -0.15 & 0.08 & -0.30 & -0.31 & -0.03 & -0.14 & 0.40 & 0.00 & 0.13 & -0.15 & -0.56 & -0.190 .23 & 1.00 & \\
\hline South & 0.41 & 0.49 & 0.00 & 1.00 & 624 & -0.06 & -0.06 & -0.40 & 0.27 & 0.03 & 0.06 & 0.07 & 0.10 & 0.03 & -0.28 & 0.22 & 0.34 & $-0.42-0.49$ & -0.32 & 1.00 \\
\hline
\end{tabular}




\section{Results}

\section{Adoption of PBF}

Given the binary nature of our adoption variable, I estimated a series of logit models (Long \& Freese, 2014). Table 10 presents the results for the adoption model. Three variables are significant: the performance of the higher education system, the presence of a Republican governor, and the percentage of Republicans in the legislature. As expected, the performance of the system is negatively related to adoption - states with struggling higher education systems are more likely to adopt performance-based funding. Similarly, having a Republican governor and a legislature dominated by the Republican Party are both positively associated with the decision to adopt performance-based funding. When using the fixed year effects, the diffusion proxy is negatively significant — a surprising finding because it contradicts Walker's (1969) theory, which specifies that the probability of a state adopting a new policy is higher if other states have already adopted the policy.

Table 10. Logit Results, Adoption Model

\begin{tabular}{lccc}
\hline \multicolumn{1}{c}{ ADOPTION } & $\begin{array}{c}\text { Year fixed } \\
\text { effects: no }\end{array}$ & $\begin{array}{c}\text { Year fixed } \\
\text { effects: } \text { yes }\end{array}$ & $\begin{array}{c}\text { Marginal } \\
\text { Effects } \\
\text { dy/dx }\end{array}$ \\
\hline $\begin{array}{l}\text { Average U.S. News } \\
\text { Performance }\end{array}$ & $-7.76^{* *}$ & $-6.09^{* *}$ & -0.74 \\
Republican Governor & $(2.02)$ & $(1.99)$ & $(0.35)$ \\
\hline $\begin{array}{l}\text { Percent of Republican } \\
\text { Legislature }\end{array}$ & $1.07^{* *}$ & $1.06^{*}$ & 0.10 \\
Ratio of Neighboring States & $(0.40)$ & $(0.44)$ & $(0.60)$ \\
with PBF over Total No. of & $6.08^{* *}$ & 4.21 & 0.58 \\
States & $(2.30)$ & $(2.70)$ & $(0.34)$ \\
\hline
\end{tabular}




\begin{tabular}{|c|c|c|c|}
\hline ADOPTION & $\begin{array}{l}\text { Year fixed } \\
\text { effects: no }\end{array}$ & $\begin{array}{l}\text { Year fixed } \\
\text { effects: yes }\end{array}$ & $\begin{array}{c}\text { Marginal } \\
\text { Effects } \\
\text { dy/dx }\end{array}$ \\
\hline Total Number of Legislators & $\begin{array}{l}-0.00 \\
(0.02)\end{array}$ & $\begin{array}{l}-0.01 \\
(0.02)\end{array}$ & $\begin{array}{l}-0.00 \\
(0.00)\end{array}$ \\
\hline Unemployment Rate & $\begin{array}{l}-0.25^{*} \\
(0.10)\end{array}$ & $\begin{array}{l}-0.18 \\
(0.26)\end{array}$ & $\begin{array}{l}-0.02 \\
(0.01)\end{array}$ \\
\hline $\begin{array}{l}\text { Personal Income/Total } \\
\text { Revenue }\end{array}$ & $\begin{array}{l}6.21^{\wedge} \\
(3.35)\end{array}$ & $\begin{array}{c}4.37 \\
(3.77)\end{array}$ & $\begin{array}{c}0.59 \\
(0.41)\end{array}$ \\
\hline Sales Tax/Total Revenue & $\begin{array}{l}5.54 * \\
(2.67)\end{array}$ & $\begin{array}{l}6.86^{\wedge} \\
(3.85)\end{array}$ & $\begin{array}{c}0.53 \\
(0.36)\end{array}$ \\
\hline $\begin{array}{l}\text { Higher Education Total } \\
\text { Expenses }\end{array}$ & $\begin{array}{l}-29.61 * * \\
(7.70)\end{array}$ & $\begin{array}{c}-17.62^{\wedge} \\
(9.73)\end{array}$ & $\begin{array}{l}-2.81 \\
(1.54)\end{array}$ \\
\hline Midwest & $\begin{array}{l}1.88 \\
(2.05)\end{array}$ & $\begin{array}{l}1.91 \\
(2.06)\end{array}$ & $\begin{array}{c}0.26 \\
(0.38)\end{array}$ \\
\hline Northeast & $\begin{array}{l}-3.17 \\
(2.74)\end{array}$ & $\begin{array}{l}-3.14 \\
(2.82)\end{array}$ & $\begin{array}{l}-0.15 \\
(0.10)\end{array}$ \\
\hline South & $\begin{array}{l}-1.92 \\
(2.05)\end{array}$ & $\begin{array}{l}-1.99 \\
(2.06)\end{array}$ & $\begin{array}{l}-0.17 \\
(0.19)\end{array}$ \\
\hline \multirow[t]{2}{*}{ Rho } & 0.74 & 0.75 & \\
\hline & $(0.09)$ & $(0.08)$ & \\
\hline LR test $f$ rho $=0$ : $\operatorname{chibar} 2(01)=$ & 147.31 & 154.25 & \\
\hline $\operatorname{Prob}>=$ chibar $2=$ & 0.000 & 0.000 & \\
\hline Log likelihood= & -170.09 & -157.96 & \\
\hline Wald chi2(12)= & 52.83 & 63.21 & \\
\hline $\mathbf{N}$ & 574 & 574 & \\
\hline${ }^{\wedge} \mathrm{p}<0.10, * \mathrm{p}<0.05, * * \mathrm{p}<0.01$ & & & \\
\hline
\end{tabular}

The results of the logit regression are expressed in terms of odds ratio. For each additional point in the Average U.S. News ranking, the odds of adopting a performance system are 7.76 times lower. Similarly, if a Republican governor is in office and a higher percentage of Republicans are in the legislature, the odds of adopting are 1.07 and 6.08 
larger, respectively. Lastly, when there is a higher proportion of neighboring states with PBF, the odds of adoption decrease by 3.81 times. Logit assumes that all other variables are held constant.

I also explored marginal effects. A marginal effect measures the change in the probability of an outcome for a change in the independent variable, holding all other independent variables constant at specific values (Long \& Freese, 2014). From the marginal effects, I gathered that as performance of the higher education system increases, the probability of adopting decreases -0.74 . Whereas, the other two main independent variables of interest, the presence of a Republican governor and the percentage of Republicans in the legislature, are associated with an increase in the probability of adoption. As in the logit models, the diffusion proxy is associated with a decreased probability of adoption.

\section{Stringency of PBF}

The stringency model was estimated with ordinary least squares (OLS) regression, calculating the effects of each independent variable on of the Performance Funding Uncertainty Index (PFUI). Table 11 below shows the results. The independent variables explain 0.57 and 0.59 of the variation of the PFUI for the models with no year fixed effects and with positive year fixed effects, respectively. 
Table 11. Regression Results, Stringency Model

\begin{tabular}{lcc}
\hline \multicolumn{1}{c}{ STRINGENCY } & $\begin{array}{c}\text { Year } \\
\text { fixed } \\
\text { effects: } \\
\text { no }\end{array}$ & $\begin{array}{c}\text { Year } \\
\text { fixed } \\
\text { effects: } \\
\text { yes }\end{array}$ \\
\hline Years PBF is Present & $0.76^{* *}$ & $0.75^{* *}$ \\
Years PBF is Present Squared & $(0.17)$ & $(0.17)$ \\
\hline Average U.S. News Performance & $-0.02^{*}$ & $-0.02^{*}$ \\
& $(0.01)$ & $(0.01)$ \\
\hline Republican Governor & -0.40 & -0.20 \\
& $(0.60)$ & $(0.68)$ \\
\hline Percent of Republican Legislature & 0.25 & 0.20 \\
Ratio of Neighboring States with PBF over & $(0.28)$ & $(0.28)$ \\
Total No. of States & $4.03^{* *}$ & $3.59^{\wedge}$ \\
Total Number of Legislators & $(1.51)$ & $(1.96)$ \\
\hline Unemployment Rate & 0.41 & -0.59 \\
& $(0.85)$ & $(1.18)$ \\
\hline Personal Income/Total Revenue & 0.00 & 0.00 \\
& $(0.01)$ & $(0.01)$ \\
\hline Sales Tax/Total Revenue & -0.03 & 0.12 \\
\hline Higher Education Total Expenses & $(0.04)$ & $(0.12)$ \\
\hline Midwest & $2.73^{*}$ & 2.14 \\
& $(1.26)$ & $(1.40)$ \\
\hline Northeast & 1.37 & 1.29 \\
& $(2.30)$ & $(2.32)$ \\
\hline & -7.44 & -3.93 \\
& $(5.08)$ & $(5.39)$ \\
\hline & -0.16 & -0.09 \\
& $(0.64)$ & $(0.60)$ \\
\hline & -0.31 & -0.23 \\
& $(0.88)$ & $(0.74)$ \\
\hline & -0.08 & 0.74 \\
& $(0.51)$ & $(0.50)$ \\
\hline & & \\
\hline & & \\
& &
\end{tabular}




\begin{tabular}{lcc}
\hline STRINGENCY & $\begin{array}{c}\text { Year } \\
\text { fixed } \\
\text { effects: } \\
\text { no }\end{array}$ & $\begin{array}{c}\text { Year } \\
\text { fixed } \\
\text { effects: } \\
\text { yes }\end{array}$ \\
\hline R-sq: within & 0.39 & 0.41 \\
R-sq: between & 0.81 & 0.82 \\
R-sq: overall & 0.57 & 0.59 \\
\hline Wald chi2(14) & 531.70 & 5047.43 \\
\hline Prob $>$ chi2 & 0.00 & 0.00 \\
\hline Sigma_u & 0.75 & 0.77 \\
Sigma_e & 1.66 & 1.65 \\
\hline Rho & 0.17 & 0.18 \\
\hline N & 574 & 574 \\
\hline p $<0.10, * p<0.05, * * p<0.01$ & & \\
\hline
\end{tabular}

The number of years the PBF is present is consistently significant with a small coefficient $(<1)$. The coefficient for the squared number of years variable is even smaller $(<0.02)$ and also significant, suggesting that the stringency of the performance system diminishes over time. Figure 6 shows the trajectory of the stringency. The graph is a Stata predication about the anticipated trajectory for the level of stringency as time passes. What is exhibited is an increasingly stringent system as time passes, which reaches a tipping point at the 17-year mark, after which stringency is likely to decrease. Another important aspect to note is that the percent of Republicans in the legislature was positive; that is, Republicans in the legislature result in an increase of 4.03 units on the level of stringency. The other main independent variables were not significant. 
Figure 6. Predictive Margins: Anticipated trajectory of Stringency Level vs. Time

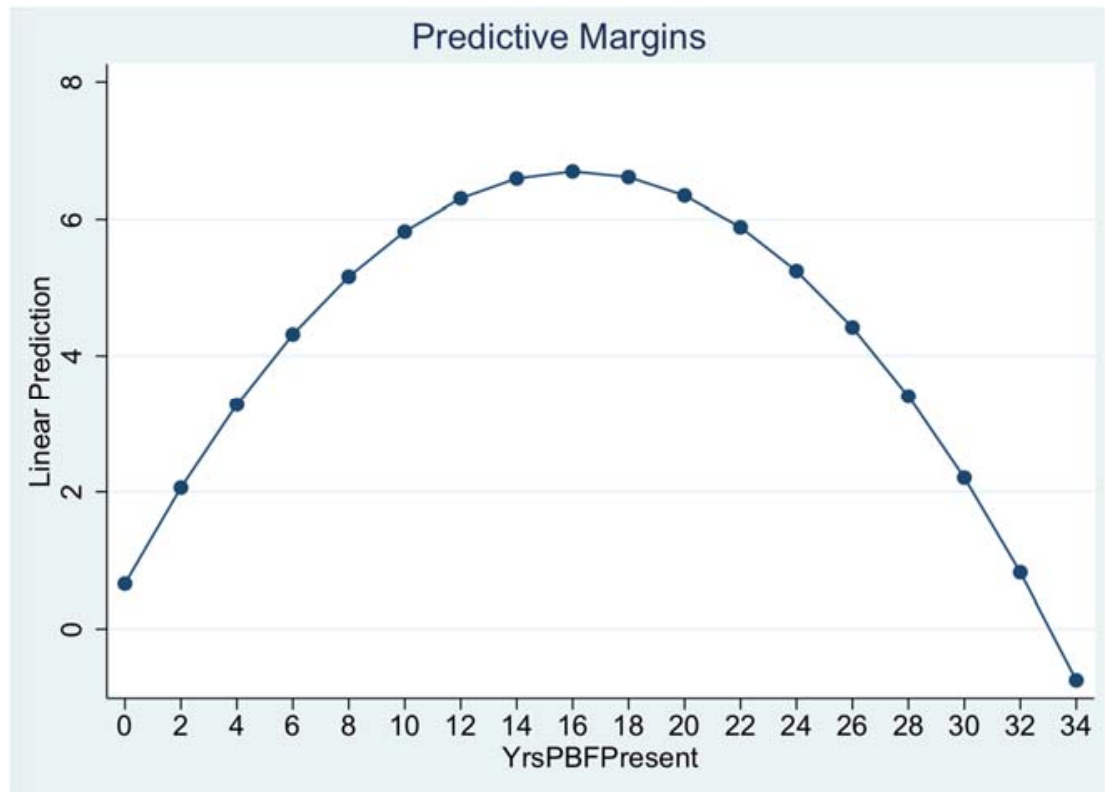

As previously mentioned, the coefficients shown in both models are expressed in terms of random effects, as supported by the Hausman test. For the adoption model, the performance proxy results continue to be significant under fixed effects, as well as the Republican Governor and the percentage of Republicans in the legislature. The effect, however, is much larger using the fixed effects (the coefficient is -13.17 compared to the random effect coefficient of 7.76). In all cases, the coefficients of the significant variables are larger under the fixed effect approach. In the case of the stringency model, the time variable continues to be significant. The size of the coefficient for the squared variable is the same (-0.02). The fixed effect approach results in a significant coefficient for the performance proxy at the $10 \%$ level, with a coefficient of -3.178 . The percentage of Republicans in the legislature continues to be significant under the fixed effect, with a coefficient of 4.37 . 


\section{Regression Diagnostics}

Diagnostic tests were performed for the main regression model. Use of the principal component approach and the additive index yielded the same results - in terms of significance and coefficient—so diagnostics were only run for the model with PCF. When performing a multiple regression, we want the estimators to be BLUE: Best Linear Unbiased Estimators. In order for the estimators to be BLUE, we have to verify that the assumptions of OLS hold. Multiple regression assumes a linear relationship between the variables. To examine this assumption, one method is to plot the standardized residuals of the regression against each independent variable. The graphs have been included under Appendix 2. There is no clear pattern, except that there are more negative residuals observed for higher values of the number of years the PBF model is present. For the degrees/enrollment variable, the residuals are nearly 0 . I did not find any "bowed" pattern, which would indicate that the model made systematic errors.

While normality is not required for the estimates to be BLUE, it is important to test for normality to validate the $\mathrm{t}$ - and p-values. Using the kernel density plot of residuals, we see significant deviation from the theoretical normal one distribution (refer to Appendix 3 for the plots). The normal probability plot reveals sensitivity to nonnormality in several sections of the data. Normality issues are also observed in the normal quantile plot, particularly in the middle section of the graph. The skewness/kurtosis test for normality in the model had a Prob $>$ chi2 $=0.00$ indicating there was an issue because it was less than 0.05 and the null hypothesis is rejected. To further explore the normality of the residuals, a Shapiro-Wilk W test was conducted. This test 
confirmed that there is a normality issue with the residuals in the model, because the $\operatorname{Prob}>\mathrm{z}=0$.

For all tests, there seemed to be issues of normality. There are different ways to deal with normality, such as transformation of central variables. Because of the normality issues that were found, the present results should be used with caution. The normality assumption states that we are as likely to overestimate regression scores as we are to underestimate them. If this assumption is violated, the confidence intervals may be too wide or too narrow.

Researchers at the Duke University Fuqua School of Business have suggested that "technically, the normal distribution assumption is not necessary if you are willing to assume the model equation is correct and your only goal is to estimate its coefficients and generate predictions in such a way as to minimize mean squared error" (n.d., Violations of normality section, paragraph 2). We must therefore, use the estimates from the model with caution, with the understanding that a significant violation of the normal distribution (as seems to be present in this model) suggests that there may be a bigger problem with the data or simply that there is a more appropriate model that better explains the relationship between the variables. In addition, Kroll (2015) suggested that the normality assumption can be relaxed if $n=100$, or if $n=500$. In this case, the sample was 532 observations. Therefore, we could relax this assumption.

The homoscedasticity test in both models, using the residual plotting tool in Stata, revealed that as the PFUI increase, the positive residuals systematically decrease, and negative residuals decrease. Using Cameron \& Trivedi's (1990) test, we obtain a p-value of 0.000 and, therefore, reject the null. To confirm whether these results are accurate, I 
conducted the Bresch-Pagan/Cook-Weisberg test. The prob $>$ chi $2=0.000$, and we therefore reject the null, indicating an issue. To make sure the results address this discrepancy, the regressions were run by using robust standard errors, which will make the significance tests more conservative.

The last test performed aimed at identifying outliers, which may affect regression results. As some of the independent variables increase, the dependent variable stays constant. This is the case for states with no performance funding in place. Finally, I tested for multicollinearity. Both models of adoption and stringency do not have any issues. The average value obtained was 2.25 and 3.34, respectively.

\section{Findings and Discussion}

I estimated the adoption model with logit regression by calculating the effects of each independent variable on the probability of adoption of a performance-based system, while holding the other independent variables constant. It was hypothesized that performance flows and conservative ideology predicted adoption, because low performance requires action and political ideology affects how politicians respond (for example, Republicans are likely to select into PBF practices).

The coefficient of the performance variable is indeed negative and significant at the $1 \%$ level. As suggested in the performance literature, the improvement of performance is a vital goal of a performance system (Rabovsky, 2012). Thus, the present data supports the hypothesis that deficits in achievements, as defined by the entity's goals and mission, will result in the adoption of a performance system. Future research should consider another unit of analysis, other than the state. 
As demonstrated by prior research, a state is more likely to adopt policies that are skeptical of bureaucracy when more Republicans are elected to the state legislature (McLendon et al., 2006). The presumption under the adoption of a performance system is that there is a need for improvement. Thus, elected officials will be likely to implement performance systems to hold the bureaucracy accountable. The present data support our hypothesis that a conservative political ideology is associated with adoption of a performance system, which is aligns with the existing literature. My findings suggest that having a Republican Governor and a higher proportion of Republicans in the legislature increase the likelihood of adoption of performance-based budgeting.

The classic theory of diffusion (Walker, 1969) did not fully explained the adoption of a performance system. The negative coefficient suggests an inverse relationship and fails to achieve statistical significance at the conventional levels.

The stringency model was estimated using an OLS regression, calculating the effect of each independent variable on the PFUI, while holding other independent variables constant. Here, neither the coefficient of the performance variable, nor one of the variables operationalizing political conservatism (having a Republican Governor), were returned as significant. The proportion of Republican legislature is significant and suggests that it is associated with a more stringent system. This finding suggests that performance and political ideology influence adoption but may not be helpful in explaining stringency: they force states to act (e.g., adopt a new policy) but provide little direction regarding the particular configuration of the implemented PBF system. As in the adoption model, the diffusion variable has not been significant here, either. 
A limitation of the stringency model is that the dependent variable is only five dimensions: benchmarking, percentage, impact to base, complexity, and penalty. It is possible that not all aspects of a PBF are captured by the index. Certain factors are difficult to measure and can only be captured through other methods of data collection, such as interviews, case studies, etc. Future research should consider use of qualitative research techniques.

The most significant finding from this analysis is the importance of time. The variable that captures the years of operation for the performance system is consistently significant at the $1 \%$ level. All model iterations returned similar results. The findings can be interpreted as follows: for every additional year the PBF is in place, stringency is expected to increase by 0.76 points. Figure 6 presents an increasingly stringent system over time. The squared term for time was included in the model to evaluate the nonlinear effect of time. The estimators from the analysis are significant. The findings reveal that the stringency reaches a certain plateau, after which it begins to decrease. This finding is novel and constitutes a contribution to the literature. Prior research has mainly addressed this issue from a principal-agent perspective (Heinrich \& Marschke, 2010). The data show that the learning curve initially increases the stringency of the performance model, but then it reaches a tipping point. A plausible explanation is that policymakers become less excited about the PMS model or because their attention is diverted to a more salient issue. A possible explanation is that we may see different generations of PBF systems: early-stage adopters experimented with a soft version of PBF; whereas middle-stage states adopted stricter NPM-style systems. The late-stage adopters do less (perhaps due to 
NPM fatigue). Determining the reasons for this diminishing trend is an important research question for the future.

From these findings, I can deduct that the configuration of the PBF system (i.e., its stringency) changes over time as a result of state learning through use. A plausible explanation is that experience seems more important than original motivation. Systems may become more stringent at first (to address strategic behavior and system errors), but will eventually stagnate. This means that they rarely reach the maximum stringency level: either because state politicians become disillusioned about the performance system and its return on investments, or they are satisfied with the results.

\section{Limitations and Future Research}

Future research might consider the characteristics related to the bureaucracy, such as average number of years in service or level of education of the bureaucracy. This will provide further insight into the factors that affect the performance of the system, including if — and how_- performance relates to elected officials' behavior. In addition, a future research avenue should consider units of analysis other than the state. There were not many suitable options to choose from for higher education performance proxy, which would describe the performance at the state level. Also, the proxy used here, the average U.S. News Ranking, is based on a self -reported survey, which presents issues related to face validity.

In addition, other venues might consider further exploring the effect of time to determine the reasons for stagnation. One aspect to consider is whether the states are satisfied with the system. In other words, were performance systems able to deliver on their promises to improve performance? 
In terms of the diffusion hypothesis, a future analysis should consider grouping states based on factors other than geographical proximity. As alternatives to this grouping, states may be eliminated from the analysis, based on commonalities such as total state budgets, demographics, fiscal state, or political composition. In addition, policy diffusion could be studied in the context of the role of conservative organizations, such as the American Legislative Exchange Council (ALEC) and think tanks. Lastly, the present study explored only two internal factors: organization's performance and the political ideology. There are many other interesting internal factors to consider, such as the fiscal stress and a revenue diversification index.

A limitation worth highlighting is that the sample is specific to R1 institutions of higher education. In terms of generalizing the results to the broader public sector, other factors (e.g., relevant control variables) might also play a role in the decision-making process of a sector. In addition, future research may consider expanding the panel data set to include the years 2015-2018 in order to analyze more years where a performance system was in place and to further explore the effect of time.

\section{Conclusion}

The purpose of this chapter was to examine the factors that determine the adoption of a performance-based system and its stringency, and whether both were influenced by the same factors. I hypothesized that underperformance, conservative political ideology, and regional diffusion were precursors of adoption and that they were positively associated with a more stringent system. The analysis shows that adoption and stringency are not explained by the same factors. While adoption is positively associated with conservative political ideology and underperformance, it is not affected by diffusion. 
Stringency is not significantly associated with either the ideology of the governor or diffusion — only with the Republican legislature. An interesting finding is that PBF systems do not naturally become more stringent over time. Rather, they stop changing at some point, and remain constant or even decrease in stringency.

These results indicate that state legislatures dominated by politically conservative elected officials are more likely to adopt a performance system than legislatures dominated by politically liberal elected officials. In addition, the states whose education systems performed poorly are more likely to adopt a performance system. The findings provide support to states and other governments - motivated by lack of performancethat are considering adopting a performance system.

The development of the stringency index, the PFUI, is an important contribution to the literature. It furthers our understanding of the factors that affect a performance system configuration. It also provides guidance to policymakers with respect to the life of a performance system and the evolution of its stringency.

An important theoretical contribution is the link between the stringency level and time. Performance systems are largely based on the premise that they will be in-place as a long-term policy mechanism. However, the findings reveal that systems are not always adopted with the same level of stringency. The point at which a state decides to join others in policy adoption affects the performance system. In the beginning of the adoption period, during the first wave of adoptions, the systems are softer, but follow an increasing trend toward greater stringency. The trend results in an increasingly more stringent system for those who decide to implement the new PMS in the middle stage. After reaching a tipping point, the systems then follow a decreasingly stringent trend. 
Therefore, states that adopt performance systems long after the first wave of adoptions implement comparatively less stringent systems.

\section{CHAPTER 4}

\section{The Impact of Performance-based Funding in Higher Education}

Universities have an array of goals that are diverse and, at times, not easily quantified; thus, it is often difficult to use performance-based accountability policies in higher education (Rabovsky, 2014a). A small group of experts have advocated for a shift from quantifying the output to considering the outcomes (Van Dooren, 2011) so that important aspects that directly impact society are counted. In higher education, a dimension that has been neglected in PBF is the mission of the institution - primarily because it is difficult to measure. The Carnegie classification system is utilized to classify institutions based on their mission (O'Meara, 2007). The mission of a research university is different from a teaching institution. The level of support and access to funds will significantly vary (Rabovsky, 2014b) from one institution to another. For example, the mission of one is to foster research and development, while the mission of another might be to nurture teaching. In general, PBF models do not capture this aspect in their formulas because they only use key performance indicators (KPIs). KPIs only measure quantifiable indicators; however, a host of other services provided in higher education institutions are unmeasurable (Van Dooren, 2011). The systematic way in which PBF in higher education connects performance information and budget allocations is rare and can pose a threat to the fundamental values of educational institutions (Bischoof \& Blaechke, 2015). 
In the previous chapter, I developed an index based on five dimensions that were identified as common traits of PBF: benchmarking, methodology used to award funds, the impact to the base budget from year-to-year, the complexity of the model and, lastly, the extent to which states may impose penalties for underperformance. Table 7 presents a brief overview of the dimensions. For the second dimension, funding methodology, most states allocate $5 \%$ to $10 \%$ of total state support based on performance (National Conference of State Legislatures, 2016. The third dimension, impact to base, examines the impact to the institution's base budget. The practice of providing a one-time bonus above the base budget (sub-category "a") is considered to be more traditional and is often classified to be the PBF 1.0 Wave; whereas the more contemporary and sophisticated practice of embedding the PBF funds as part of the base (sub-category "b") is deemed PBF 2.0 (Dougherty, Natow, Bork, Jones \& Vega, 2013).

The fourth dimension, which is based on the total number of key performance indicators (KPIs), captures the most important aspects of the PBF. KPIs are used to measure the university's performance. The number of KPIs ranges widely and may even change from year-to-year, depending on the priorities of the governors and legislatures. KPIs in higher education tend to focus on student success measures. The most utilized KPIs are graduation rates, followed by retention, year-to-year retention rates, total degrees awarded, student outcomes for minority or low-income students, and number of degrees produced (Rabovsky, 2012; Li, 2014).

PBF adoption varies across states. Each state typically establishes its own set of indicators to determine each institution's eligibility for performance funding. In general, PBF systems aim to improve outputs (e.g., student retention and graduation rates, as well 
as other student performance indicators). While institutions attempt to meet performance standards, their actions might result in changes in institutional behaviors, system gaming, and lowering admissions of students with lower socio-economic backgrounds.

As presented in Chapter 2, the literature on the impact of PMS is mixed. Most of the evidence leans toward negative, unintended, or no impact at all. For this reason, more research is needed to understand the extent to which PMS models achieve the objectives they set out to fulfill after the model is established. It is also important to understand unintended consequences associated with the system's adoption.

\section{Hypotheses on the Impact of Performance-based Funding}

While there are increased efforts to establish PBF models in higher education across the United States, they often face disapproval. PBF is a policy instrument that is not exempt from potential policy design and implementation problems (Birdsall, 2018). The inability to account for the multifaceted capacities, resources, and missions of target organizations (Heinrich, 1999; Radin, 2006) are some design related issues that have been found in previous research. The way in which PBF has been implemented in higher education creates unique challenges because it establishes "tight, automatic and formulaic" relationships between funding and performance indicators (Burke \& Minassians, 2003, p. 3). These challenges leave no room to accommodate special circumstances, such as a student's socio-economic background or the mission of the institution.

Some unintended consequences that have been linked to PBF adoption are: costs of fulfilment, tightening of institutional missions, control of student admissions, grade inflation, and diminished academic standards management disapproval, and negative 
impact to vulnerable groups (Dougherty \& Reddy, 2013; Patrick \& Rollins, 2015).

Additionally, opponents of the performance-based funding model are concerned that it will adversely influence academic excellence and rigor, and that the efforts to advance diversity and access will be weakened (Huisman \& Currie, 2004). Adoption of PBF has potential consequences, including lower student performance (Andersen, 2008) and gaming behavior following implementation (Gerrish, 2016). In addition, PBF may distract management from other important issues and introduce incentives for attaining performance goals (Birdsall, 2018). The unintended impacts of PBF adoption in higher education are important to consider because PBF may inadvertently provoke a shift away from democratic ideals for higher education institutions, such as broad and equitable access (Dougherty \& Natow, 2019), which were once top priorities of public universities. Because of the heightened focus on the negative implications following PBF adoption, the following hypothesis will be explored:

$\mathbf{H}_{1}$ : The adoption of a performance-based system will negatively impact certain mission-based results.

In general, the overall results of the research regarding the effectiveness of a PBF model have been mixed (e.g., Berman \& Wang, 2000; Melkers \& Willoughby, 2005; Sun \& Ryzin, 2014). In addition to the literature that highlights the negative aspects of PBF, another stream of research has shown that PBF does lead to better performance. After all, performance management systems aim: to enhance effectiveness, efficiency, accountability, and quality in the provision of public goods and services (Birdsall, 2018). When used effectively, performance management systems may result in agencies reevaluating essential principles of their missions, or to make fundamental changes to the 
way the organization functions (Rabovsky, 2014a; Monhiyan, 2005). An effective performance management system will help public managers run their organizations effectively (Angiola \& Bianchi, 2015).

In the case of higher education, increased instructional expenditures have been shown to be closely linked to the adoption of PBF (Rabovsky, 2012). Evidence regarding advancement of student and academic success has been linked to the administrative changes implemented by institutions following the adoption of a PBF model (Dougherty \& Reddy, 2011). In the context of public education, No Child Left Behind advanced stronger accountability for student performance (Heinrich, 2010). Hong (2018) found evidence that organizational changes are in fact driven by performance management systems and that failure to meet performance standards results in adjustments that will drive performance improvement. The adoption of PBF in higher education institutions is typically preceded by support from university personnel, who often trust that the adoption of a performance-based funding may improve outcomes (Dougherty \& Reddy, 2019). The second hypothesis will explore whether a performance-based system results in enhanced effectiveness in terms of outcomes.

\section{$\mathbf{H}_{2}$ : A performance-based system will result in better results.}

The literature on PBF effectiveness is mixed. In addition to the negative and positive results discussed in Chapter 2, prior studies have not found a strong link between a performance management system and performance outcomes (Barnow, 2000; Patrick \& Rollins, 2015; Sanger, 2013). This is concerning due to the high emphasis on adoption of a PMS, yet the systems do not seem to deliver on their promises of improved 
performance (Li \& Kennedy, 2018). A particular concern is that the PMS may be failing because performance information from the system is not being utilized (Moynihan, 2008b). The use of performance information data is a distinct area of research in the performance management literature (e.g., Bischoff \& Blaeschke, 2016; DimitrijevskaMarkoski \& French, 2019; Gerrish, 2016; Kroll, 2017; Moynihan, 2006). The non-use of performance information is, at times, deliberate; managers sometimes use other informal mechanisms to track performance (Angiola \& Banchi, 2015), such as talking to colleagues, customers, and other people instead of sophisticated performance reports (Van Dooren \& Van de Walle, 2008). When performance information is not used, one might argue that the performance management has a null effect because it is not being utilized to make the decisions that will influence the organization.

Outcomes such as improved instruction, higher graduation rates, and enhanced faculty research productivity have been shown to be weakly related to PBF adoption (Dougerty \& Natow, 2019). In the context of a large urban school district, it was found that performance management did not lead to improved performance on its own (Destler, 2016; Heinrich, 2002). Research has also shown no meaningful methodical enhancements in college completion rates (Hillman, Tandberg, \& Gross, 2014). Bischoff and Blaeschke (2016) found that PBF results in substantial social waste from its use, PBF is often as a symbolic tool. Gerrish (2016b) found that performance information alone cannot be attributed to the improvement of performance, and that other factors must be introduced. Ho (2011) found little connection between budget appropriations and performance indicators. For this reason, it is hypothesized that a PBF is not associated with neither better nor worse results; that is, the impact is null. 
$\mathbf{H}_{3}$ : A performance-based system will result in no difference in results.

Institutions of higher education have diverse and complex missions and goals. Some are easier to measure than others (time-to-graduation and retention rates), while some measures (personal growth and development, overall contributions to culture, knowledge, and diversity) are much more difficult to quantify (Rabovsky, 2014a). This relevant area of research should be studied closely. Otherwise, we might be missing an opportunity to cultivate the values that our public institutions were intended to foster. In addition, we might be ignoring less quantifiable impacts that public institutions exert within and beyond their communities.

\section{Research Design}

\section{Estimation Strategy}

A panel dataset for the years 2000 through 2015, using data from the U.S. Department of Education's Integrated Postsecondary Data System (IPEDS), was constructed. The goal was to compare the university performance when it was subject to a performance-based-funding policy to the counterfactual — that is, to a university where performance-based funding is not used. A major concern was that universities that use performance-based-funding policies substantially differ from those that do not, and that these differences may be correlated with performance. For example, PBF may have been implemented in universities with students from high socioeconomic backgrounds. In this case, using a simple cross-section comparison would produce bias, as the correlation between PBF and performance would be confounded by the unobserved effects of families with high socioeconomic status helping their children to perform well. To 
address this problem, a longitudinal approach is used, which considers time-invariant unobserved variables.

The gradual adoption of PBF among universities allows the use of a before and after difference-in-differences estimation. I used diverse sources (e.g., the National Conference of State Legislatures, state legislatures, budget documents) to identify the "adopter" universities and the "non-adopters." The adopter and non-adopter universities were identified based on whether or not the state had adopted a PBF policy during the period of 2000-2015. In the case where states had adopted a PBF before 2000, a group of adopters were classified as pre-adopters before the period of this study. In addition, six states had adopted a PBF, but later became non-adopters. This group of states was excluded from the analysis. The following model was estimated:

$$
\mathrm{y}_{\mathrm{ict}}=\alpha+\beta_{1}(\text { treat })+\beta_{2}(\text { post })+\beta_{3}(\text { treat X post })+\gamma_{\mathrm{i}}+\mu_{\mathrm{t}}+\mathrm{m}_{\mathrm{c}}+\text { controls }_{i t}+\varepsilon_{\mathrm{it}}
$$

where yict is the outcome variable of university $i(\mathrm{i}=1,2, \ldots, N)$ in year $t(t=2000$, $2001, \ldots 2015)$ and part of cohort $c(c=$ Pre-2000, 2000, 2001...2015). The treatment vector $\beta_{1}$ (treat) is a dichotomous variable used to denote universities affected by PBF. It takes the value of 0 prior to PBF adoption and .1 after adoption. The variable $\beta_{2}$ (post) is a binary indicator that equals 1 for institutions when PBF takes place. $\beta_{3}$ is the differencein-differences (DID) estimator, which measures the impact of PBF on treated institutions. The DID estimator is utilized to estimate the effect of a program policy. It is a difference estimator between the actual outcome variable that would occur in the post treatment period for the treatment group had there been no treatment. 
Year fixed-effects $\gamma_{i}$ controls for hypothetical year-specific events that may impact the outcome variable for all universities. For example, these could include national-level policy fluctuations or unpredictable fiscal events. University fixed-effects $\mu_{\mathrm{i}}$ are used to consider unobserved variables at the university level that might confound the effect of using PBF, such as quality of education, quality of the faculty, and mission. These fixed effects helped me account for omitted variable bias, thus improving our model's internal validity, so that I could more closely arrive at causal inference between the policy and the observed outcomes. In addition, my model accounted for cohort adoption dummies $\mathrm{m}_{\mathrm{c}}$ that index the different sets of universities treated by the PBF (e.g., different universities might be affected by PBF at different points in time). Universities affected at one point in time therefore become a "cohort." Although the difference-in-differences model includes year and university fixed effects, the model also controls for key variables of the university and the state because of potential year-to-year volatility in university characteristics. As the university level, I included the total undergraduate enrollment by institution, and the institution's reputation, among other elements. At the state level, I accounted for the total population poverty rate, total state appropriations, etc.

As a result of the hierarchical structure with students, the errors might be correlated within universities. For example, unobserved university variables such as administration quality or faculty quality could include correlation in the errors within universities. To account for this clustering by universities, I used cluster standard errors at the university level with the Stata command VCE. The VCE command stipulates how to estimate the variance-covariance matrix (VCE) corresponding to the parameter estimates, which in this case is the universities (StataCorp, 2013). 
The analysis was based on all public 4-year, doctoral-degree granting universities classified as Carnegie-Highest-Research activity in the U.S, which returned a sample of 82 institutions. The unit of analysis is the university. Universities were coded by cohort, based on adoption year. In each cohort, adopters for that year were compared to the states that never adopted. Thus, there are multiple entries for never-adopters - because they served as the control group for each adoption cohort. To assess a performance-based system's impact on the outcome variables (racial/ethnic minority enrollment, graduation rate, and racial/ethnic minority graduation rate), an ordinary least-squares regression was implemented using the DID technique.

DID is a quasi-experimental tool often used to evaluate the result of a specific change in financial setting or government policy, in combination with a natural experiment in which nature does the randomization (Roberts, 2016). The main assumption underlying the difference-in-differences design is that, in the absence of a PBF intervention, the average change in university performance would have been the same for adopter universities and non-adopter universities. If PBF did enhance performance, universities subject to the policy (i.e., the treatment group) would be expected to produce significantly better performance after the PBF was adopted — as compared with performance before adoption when the treatment was not in place. It is not possible to observe the counter factual (i.e., performance changes at universities subject to the PBF had the PBF not been adopted) (Roberts, 2016). To analyze the policy impact, I compared variations in the outcome within treatment and control groups before and after the PBF. This comparison offered an unbiased estimate of the policy's effect 
because the control group of universities were never subject to the PBF, yet they were exposed to the same unobserved yearly state-level time trends (Li \& Kennedy, 2018).

A key assumption of DID is a parallel trend, which means that average changes in the control and experimental groups would be the same in the absence of treatment (Wang \& Yeung, 2018). To test this assumption, more than one period of data prior to the treatment was needed. I was able to test it based on the cohort years, which accounts for the different adoption years. For example, for a university member of Cohort 14 where PBF was adopted in the year 2012, the panel data includes data before the treatment occurred (i.e., 2000-2012). The control group for this cohort would be, for example, Cohort 15 (adopted in the year 2013). The idea underlying the cohort grouping is that each group controls for each other, which allowed me to follow the parallel trends during non-treatment years. Figures 7, 8, and 9 show a graphical representation of the parallel trends for each of the dependent variables within our study. As shown in the figures, the control and experimental groups demonstrated nearly parallel trends before the adoption year. 
Figure 7. Parallel Trends Minority Enrollment

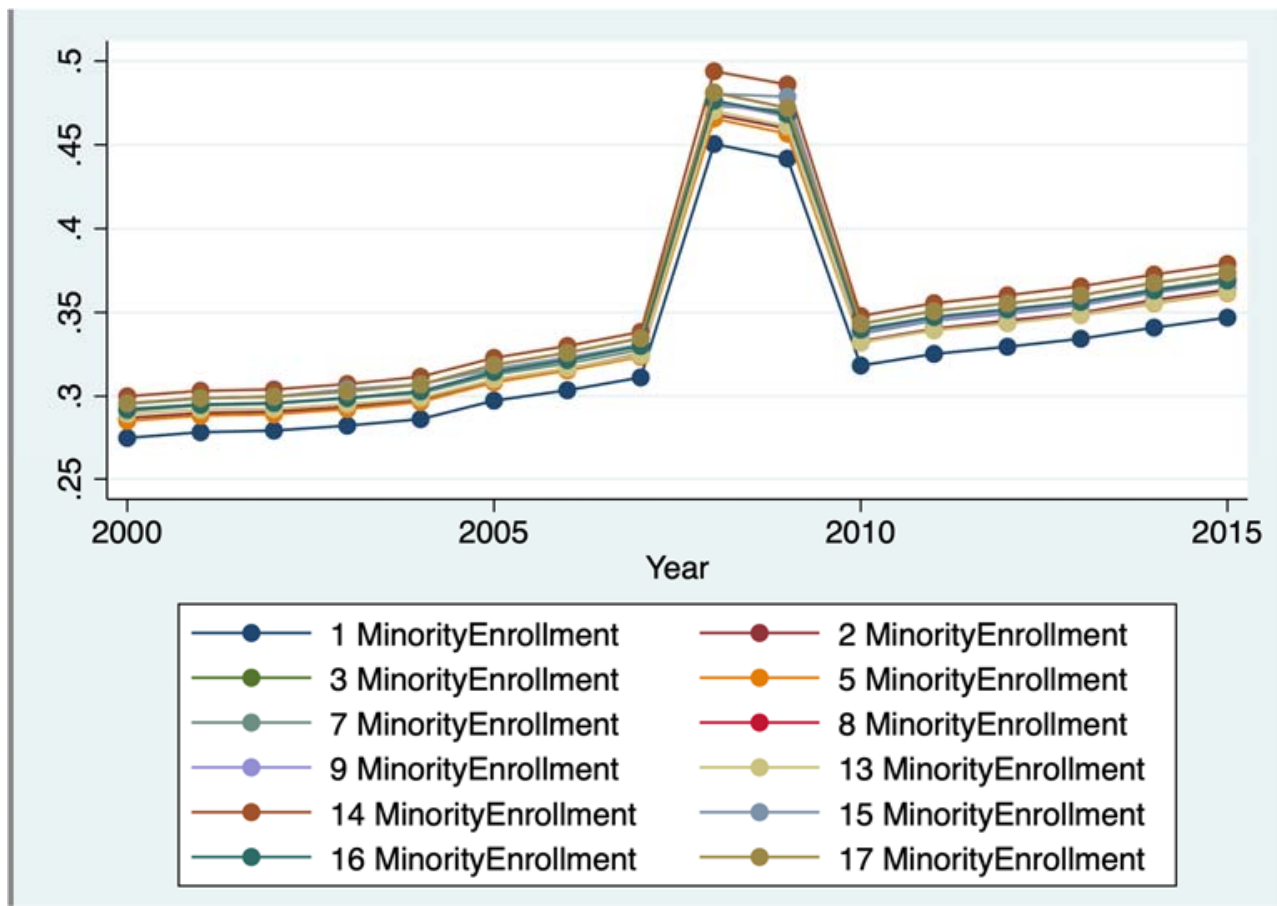

Figure 8. Parallel Trends Graduation Rate within 150\%

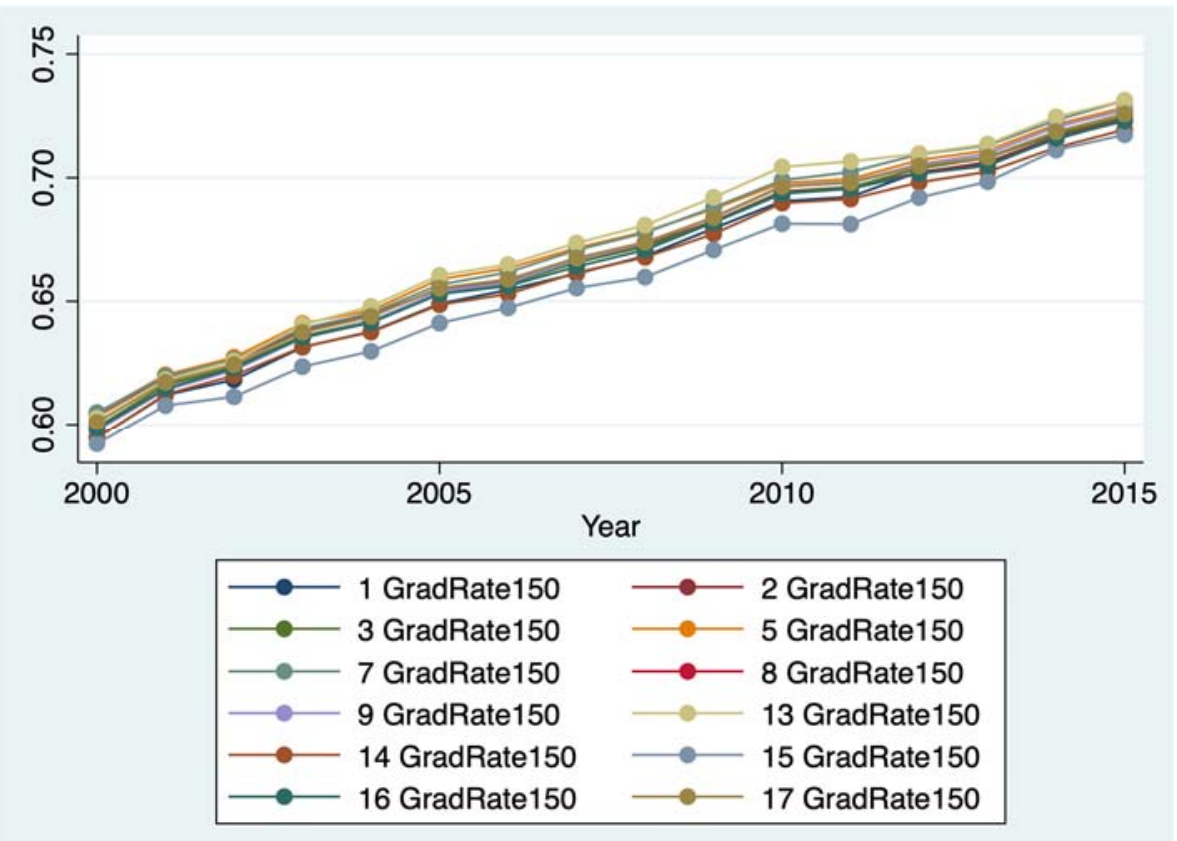


Figure 9. Parallel Trends Hispanic And African American Graduation Rate

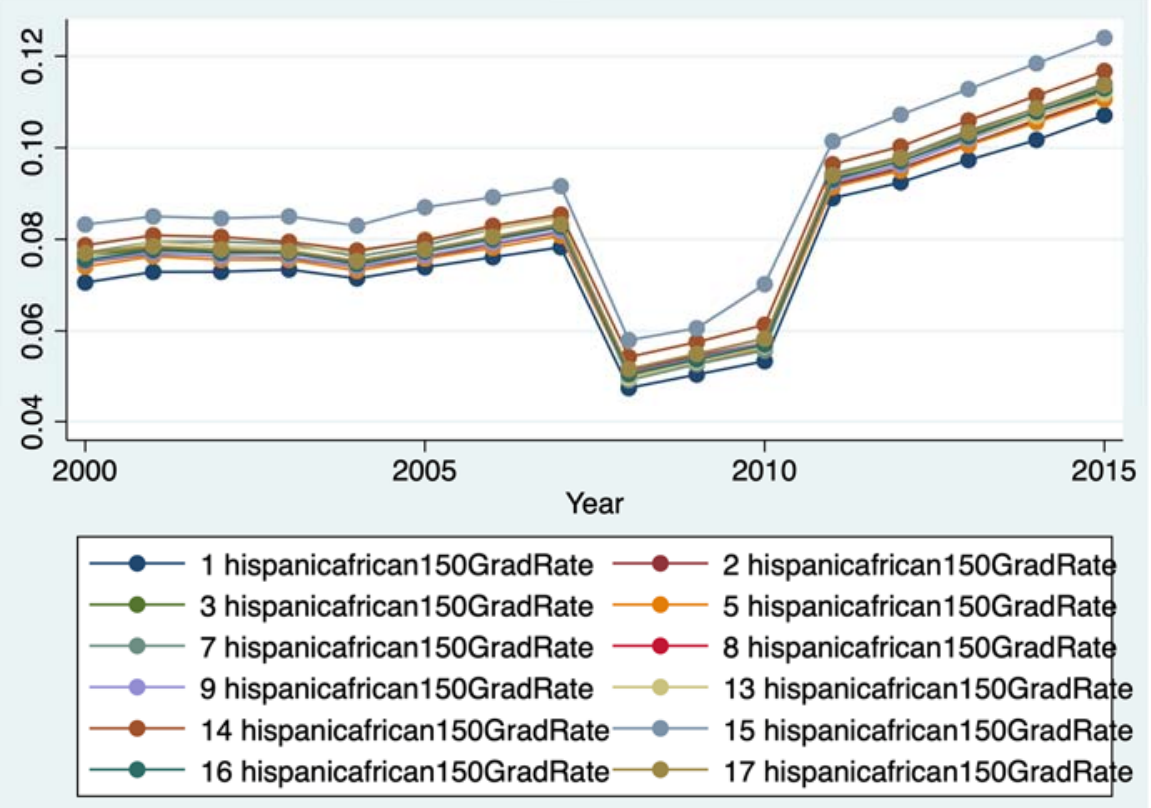

\section{Data and Measures}

I built a university-level panel dataset from 2000-2015, during which the waves of PBF adoptions for universities occurred. I operationalized the policy treatment as the presence of a state performance-based funding policy for state universities, inclusive of the adoption year. The states that had performance-based funding in the dataset enacted legislation by which some or all of the appropriations to state universities were based on performance as measured by KPIs. Several sources were used to determine the exact years during which a state operated under a performance-based-funding mechanism.

For each university that operated under such a performance-based funding policy, I coded a dummy variable as 1 during the adoption year and for each year thereafter. I considered the policy to have potential impacts beginning in the year that the legislation was scheduled to take effect. For example, if a policy was enacted in 2005 but scheduled 
to take effect in 2006 , it was coded as 1 beginning in 2006 . The policy dummy variable that I created was equal to 1 only when the state actually adopted the policy. In the case of states that adopted but later dropped out, they were coded as 0 when the PBF was discontinued. Figure 5 illustrates the states coded as 1 during the year 2015. Universities in the data set were defined in the Integrated Postsecondary Education Data System (IPEDS) as being public, 4-year institutions, and designated as Carnegie Classification Very High Research Universities. This returned a total of 82 institutions in 40 states.

The panel data set also has information regarding the universities. IPEDS offers university-level data on admissions, completions, enrollment, graduation rates, enrollment, financial aid, and finances. In addition, information regarding state appropriations and other financial information was obtained from the website of the National Association of State Budget Officers (NASBO). Other sources included the U.S. News World Report ranking, the State of Higher Education Finance (SHEF), the U.S. Bureau of Labor Statistics (BLS), and the U.S. Census Bureau.

This study models three outcome variables. They include racial/ethnic minority enrollment, overall graduation rate, and racial/ethnic minority graduation rate. Racial/ethnic minority enrollment is defined as the ratio of total enrollment of students that identify as American Indian or Alaskan, Black or African American, Hispanic and or Asian/Native Hawaiian or Other Pacific Islander over the total enrollment by institution, regardless of ethnicity. The $150 \%$ graduation rate measure was used for the overall graduation rate, which was calculated as the total number of completers within $150 \%$ of normal time divided by the adjusted cohort size. Racial/ethnic minority graduation is a measure calculated by dividing the total racial/ethnic minority graduates over the total 
number of graduates within $150 \%$ of normal time. Graduation rates and enrollment have previously been used to study the impact of PBF (Birdsall, 2018; Hillman, 2014; Rabovsky, 2012; Rutherford \& Rabovsky, 2014; Tandberg \& Hillman, 2014; McKinney \& Hagedon, 2015). Table 12 presents the descriptive statistics, as well as the correlation among all variables.

I selected these variables because they capture the unintended consequences that are associated with PBF adoption. In the case of public education in the United States, educational opportunity is as important as educational attainment-where opportunity encompasses issues such as justice, fairness, and an equal chance for students and their families (Frederickson, 2010). However, educational opportunities and attainment could present conflicting goals. For instance, providing opportunities to all students, regardless of their likelihood of success, could lead to lower rates of attainment. Potential factors that affect students' abilities to perform well are ethnicity, unequal access to key educational resources (e.g., skilled teachers), and quality curriculum and income levels (Darling-Hammond, 2007). In other words, the combination of factors linked to students' social backgrounds could have a significant negative impact on their academic performance. For these reasons, I chose racial/ethnic minority enrollment and graduation rates of Hispanic and African-American students as proxies to measure unintended consequences. The rationale is that the emphasis on student success metrics (e.g., graduation, retention, and employment) may negatively impact the enrollment of certain populations, which have been previously shown to negatively affect students' abilities to succeed. 
To better segregate the effects of PBF, I included a series of time-varying university and state level variables from IPEDS and other sources. A number of variables that have previously been verified or used in other studies were included, such as enrollment intensity of students. This measures the percentage of part-time students among the overall student headcount (Hillman et al., 2015). Racial divide was also included as an independent variable of interest. This accounts for the factor of race; it has been previously demonstrated that racial minorities tend to perform lower than their White counterparts in education (Woodridge \& Gooden, 2014). Control variables were used for the analysis: total undergraduate enrollment, the performance of the University as measured by the U.S. News Ranking system, enrollment intensity, poverty rate, unemployment rate, total state appropriations, tuition, and fee revenues, as well as total revenues. The use of these variables aligns with prior studies that analyze performancebased mechanisms (Birdsall, 2018; Hillman et al., 2015). The appendix includes additional information regarding the measures and their sources.

\section{Results}

Table 13 presents the parameter estimates from the model formalized in this paper. Results are presented for the models of the three outcome variables of interest: racial/ethnic minority enrollment, graduation rate for all, and graduation rate for racialethnic minorities. On average, none of the three outcomes exhibited significant changes in response to performance-based funding. Had universities not been subject to PBF, they would have performed at the same level as the other institutions in terms of racial/ethnic minority enrollment, graduation rate for all students, and graduation rate for racial/ethnic minorities. The overall graduation rate coefficient (model 2B) shows some significance at 
the $10 \%$ level, but the effect is very small, nearly 0 . Therefore, is a small positive association between adopting a PBF and the increase of graduation rates for all students. These models did not include six states that adopted a PBF model but that later discontinued use of PBF. The effects including these states are comparable. The results are not surprising.

These findings contribute to the mixed body of literature regarding the effect of PBF systems (Gerrish, 2016; Kroll, 2017; Moynihan \& Pandey, 2016). However, the results seem to align more closely with research that argues that performance-based funding policies produce no results (Destler, 2016; Heinrich, 2002). 
Table 12. Descriptive Statistics, Impact Model

\begin{tabular}{|c|c|c|c|c|c|c|c|c|c|c|c|c|c|c|c|c|c|c|c|c|c|}
\hline Name & Obs & Mean & Std. Dev. & Min & $\operatorname{Max}$ & 1 & 2 & 3 & 4 & 5 & 6 & 7 & 8 & 9 & 10 & 11 & 12 & 13 & 14 & 15 & 16 \\
\hline $\begin{array}{l}\text { 1. Racial-Ethnic } \\
\text { Minority } \\
\text { Enrollment }\end{array}$ & 7,526 & 0.343 & 0.200 & 0.07 & 0.98 & 1.000 & & & & & & & & & & & & & & & \\
\hline $\begin{array}{l}\text { 2. Graduation } \\
\text { Rate } 150 \%\end{array}$ & 7,334 & 0.669 & 0.147 & 0.27 & 0.95 & 0.206 & 1.000 & & & & & & & & & & & & & & \\
\hline $\begin{array}{l}\text { 3. Minority } \\
\text { Graduation Rate } \\
150 \%\end{array}$ & 7,334 & 0.082 & 0.510 & 0.01 & 0.46 & 0.639 & 0.230 & 1.000 & & & & & & & & & & & & & \\
\hline 4. Treat & 7,648 & 0.035 & 0.184 & 0 & 1 & -0.112 & -0.010 & -0.05 & 1.000 & & & & & & & & & & & & \\
\hline 5. Post & 7,648 & 0.542 & 0.498 & 0 & 1 & 0.027 & 0.103 & 0.085 & 0.170 & 1.000 & & & & & & & & & & & \\
\hline 6. UG Enrollment & 7,588 & 21433 & 7495 & 8 & 59382 & 0.0618 & 0.202 & 0.192 & 0.101 & 0.077 & 1.000 & & & & & & & & & & \\
\hline $\begin{array}{l}\text { 7. US News } \\
\text { Average }\end{array}$ & 7,456 & 3.064 & 0.366 & 2.2 & 3.9 & 0.182 & 0.426 & -0.007 & -0.092 & -0.047 & -0.171 & 1.000 & & & & & & & & & \\
\hline 8. Racial Divide & 7,588 & 0.574 & 0.226 & 0 & 0.91 & -0.807 & -0.273 & -0.550 & 0.101 & -0.068 & -0.019 & -0.270 & 1.000 & & & & & & & & \\
\hline $\begin{array}{l}\text { 9. Enrollment } \\
\text { Intensity }\end{array}$ & 7,588 & 0.133 & 0.125 & 0.02 & 1 & -0.002 & -0.750 & -0.048 & 0.030 & -0.064 & 0.053 & -0.461 & 0.099 & 1.000 & & & & & & & \\
\hline 10. Poverty Rate & 7,648 & 13.66 & 2.898 & 5.7 & 23.1 & 0.284 & -0.174 & 0.285 & -0.051 & 0.062 & 0.063 & -0.483 & -0.158 & 0.194 & 1.000 & & & & & & \\
\hline $\begin{array}{l}11 . \\
\text { Unemployment } \\
\text { Rate }\end{array}$ & 7,456 & 6.282 & 2.023 & 2.2 & 13.09 & 0.386 & 0.242 & 0.072 & -0.050 & 0.018 & -0.010 & 0.133 & -0.372 & -0.186 & 0.389 & 1.000 & & & & & \\
\hline $\begin{array}{l}\text { 12. State } \\
\text { Appropriations }\end{array}$ & 6,443 & $2.68^{\wedge} 8$ & $1.31^{\wedge}$ & 0 & $7.02^{\wedge} 8$ & 0.035 & 0.651 & 0.072 & -0.061 & 0.018 & 0.330 & 0.152 & -0.103 & -0.434 & -0.103 & 0.154 & 1.000 & & & & \\
\hline $\begin{array}{l}\text { 13. Tuition and } \\
\text { Fees }\end{array}$ & 6,443 & $2.24^{\wedge} 8$ & $1.39^{\wedge} 8$ & $1.13^{\wedge} 7$ & & 0.141 & 0.537 & 0.207 & 0.148 & 0.250 & 0.609 & 0.085 & -0.203 & -0.265 & 0.016 & 0.180 & 0.357 & 1.000 & & & \\
\hline 14. All Revenues & 6,443 & $1.46^{\wedge} 9$ & $1.09^{\wedge} 9$ & $1.08^{\wedge} 8$ & & 0.203 & 0.659 & 0.158 & 0.013 & 0.119 & 0.409 & 0.287 & -0.254 & -0.379 & -0.017 & 0.2162 & 0.629 & 0.751 & 1.000 & & \\
\hline $\begin{array}{l}\text { 15. Proportion of } \\
\text { State App over } \\
\text { All Revenues }\end{array}$ & 6,443 & .240 & 0.113 & 0 & 0.77 & -0.252 & -0.346 & -0.161 & -0.109 & -0.177 & -0.288 & -0.184 & 0.217 & 0.133 & -0.102 & -0.168 & -0.009 & -0.608 & -0.650 & 1.000 & \\
\hline 16. Population & 7,636 & $16 / 15$ & 1.065 & 13.56 & 17.48 & 0.771 & 0.233 & 0.661 & -0.124 & 0.016 & 0.118 & 0.095 & -0.647 & -0.053 & 0.442 & 0.307 & 0.042 & 0.084 & 0.136 & -0.118 & 1.000 \\
\hline
\end{tabular}


Table 13. Regression Results, Impact Model

\begin{tabular}{|c|c|c|c|c|c|c|}
\hline \multirow[t]{2}{*}{ IMPACT } & \multicolumn{2}{|c|}{$\begin{array}{c}\text { RACIAL/ETHNIC } \\
\text { MINORITY } \\
\text { ENROLLMENT }\end{array}$} & \multicolumn{2}{|c|}{$\begin{array}{c}\text { GRADUATION } \\
\text { RATE | ALL } \\
150 \%\end{array}$} & \multicolumn{2}{|c|}{$\begin{array}{c}\text { GRADUATION } \\
\text { RATE | } \\
\text { MINORITY } 150 \%\end{array}$} \\
\hline & (1a) & (1b) & (2a) & (2b) & (3a) & (3b) \\
\hline Treat x Post & $\begin{array}{l}-0.02 \\
(0.02)\end{array}$ & $\begin{array}{l}-0.00 \\
(0.01)\end{array}$ & $\begin{array}{l}-0.00 \\
(0.02)\end{array}$ & $\begin{array}{l}0.02^{\wedge} \\
(0.01)\end{array}$ & $\begin{array}{c}0.00 \\
(0.01)\end{array}$ & $\begin{array}{c}0.00 \\
(0.01)\end{array}$ \\
\hline Post & $\begin{array}{c}0.00 \\
(0.00)\end{array}$ & $\begin{array}{c}0.00 \\
(0.00)\end{array}$ & $\begin{array}{l}0.00^{\wedge} \\
(0.00)\end{array}$ & $\begin{array}{c}0.00 \\
(0.00)\end{array}$ & $\begin{array}{c}0.00 \\
(0.00)\end{array}$ & $\begin{array}{c}0.00 \\
(0.00)\end{array}$ \\
\hline UG Enrollment & $\begin{array}{l}-0.00 \\
(0.00\end{array}$ & $\begin{array}{c}0.00 \\
(0.00)\end{array}$ & $\begin{array}{l}-0.00 \\
(0.00\end{array}$ & $\begin{array}{l}-0.00^{*} \\
(0.00)\end{array}$ & $\begin{array}{c}0.00 \\
(0.00\end{array}$ & $\begin{array}{c}0.00 \\
(0.00)\end{array}$ \\
\hline US News Average & $\begin{array}{c}0.01 \\
(0.04)\end{array}$ & $\begin{array}{l}0.14^{*} \\
(0.06)\end{array}$ & $\begin{array}{l}-0.01 \\
(0.03)\end{array}$ & $\begin{array}{c}0.04 \\
(0.03)\end{array}$ & $\begin{array}{l}-0.03^{\wedge} \\
(0.01)\end{array}$ & $\begin{array}{l}0.06^{\wedge} \\
(0.04)\end{array}$ \\
\hline Racial Divide & $\begin{array}{c}-0.40 * * \\
(0.08)\end{array}$ & $\begin{array}{c}0.04 \\
(0.03)\end{array}$ & $\begin{array}{c}0.03 \\
(0.04)\end{array}$ & $\begin{array}{l}-0.01 \\
(0.01)\end{array}$ & $\begin{array}{c}- \\
0.09^{* *} \\
(0.03)\end{array}$ & $\begin{array}{r}-0.03 * \\
(0.01)\end{array}$ \\
\hline $\begin{array}{l}\text { Enrollment } \\
\text { Intensity }\end{array}$ & $\begin{array}{l}0.37 * * \\
(0.11)\end{array}$ & $\begin{array}{l}-0.07 \\
(0.06)\end{array}$ & $\begin{array}{l}-0.75 \\
(0.11)\end{array}$ & $\begin{array}{l}-0.06 \\
(0.13)\end{array}$ & $\begin{array}{l}-0.05 \\
(0.05)\end{array}$ & $\begin{array}{l}-0.00 \\
(0.07)\end{array}$ \\
\hline Poverty Rate & $\begin{array}{l}-0.00 \\
(0.01)\end{array}$ & $\begin{array}{l}-0.00^{\wedge} \\
(0.00)\end{array}$ & $\begin{array}{c}- \\
0.01 * * \\
(0.00)\end{array}$ & $\begin{array}{c}0.00 \\
(0.00)\end{array}$ & $\begin{array}{l}-0.00 \\
(0.00\end{array}$ & $\begin{array}{l}-0.00 \\
(0.00)\end{array}$ \\
\hline $\begin{array}{l}\text { Unemployment } \\
\text { Rate }\end{array}$ & $\begin{array}{c}0.01 \\
(0.01)\end{array}$ & $\begin{array}{c}0.01 \\
(0.01)\end{array}$ & $\begin{array}{c}0.00 \\
(0.01)\end{array}$ & $\begin{array}{l}-0.00 \\
(0.00)\end{array}$ & $\begin{array}{c}0.00 \\
(0.00)\end{array}$ & $\begin{array}{c}0.00 \\
(0.00)\end{array}$ \\
\hline $\begin{array}{l}\text { State } \\
\text { Appropriations }\end{array}$ & $\begin{array}{c}0.00 \\
(0.00)\end{array}$ & $\begin{array}{c}0.00 \\
(0.00)\end{array}$ & $\begin{array}{l}0.00^{* *} \\
(0.00)\end{array}$ & $\begin{array}{l}0.00^{* *} \\
(0.00)\end{array}$ & $\begin{array}{c}0.00 \\
(0.00)\end{array}$ & $\begin{array}{c}0.00 \\
(0.00)\end{array}$ \\
\hline Tuition and Fees & $\begin{array}{c}0.00 \\
(0.00)\end{array}$ & $\begin{array}{l}-0.00^{*} \\
(0.00)\end{array}$ & $\begin{array}{l}0.00^{* *} \\
(0.00)\end{array}$ & $\begin{array}{l}0.00^{\wedge} \\
(0.00)\end{array}$ & $\begin{array}{l}-0.00 \\
(0.00)\end{array}$ & $\begin{array}{l}-0.00 \\
(0.00)\end{array}$ \\
\hline All Revenues & $\begin{array}{l}-0.00 \\
(0.00)\end{array}$ & $\begin{array}{l}-0.00 \\
(0.00)\end{array}$ & $\begin{array}{l}-0.00^{*} \\
(0.00)\end{array}$ & $\begin{array}{l}-0.00^{\wedge} \\
(0.00)\end{array}$ & $\begin{array}{l}-0.00 \\
(0.00)\end{array}$ & $\begin{array}{l}-0.00 \\
(0.00)\end{array}$ \\
\hline $\begin{array}{l}\text { Proportion of State } \\
\text { App over All } \\
\text { Revenues }\end{array}$ & $\begin{array}{l}-0.31^{\wedge} \\
(0.16)\end{array}$ & $\begin{array}{l}-0.01 \\
(0.09) \\
\end{array}$ & $\begin{array}{c}0.41 * * \\
(0.13)\end{array}$ & $\begin{array}{c}0.04 \\
(0.05)\end{array}$ & $\begin{array}{l}-0.03 \\
(0.09)\end{array}$ & $\begin{array}{c}0.00 \\
(0.03)\end{array}$ \\
\hline Population & $\begin{array}{l}0.10^{* *} \\
(0.01)\end{array}$ & $\begin{array}{l}0.56^{*} \\
(0.11)\end{array}$ & $\begin{array}{l}0.04 * * \\
(0.01)\end{array}$ & $\begin{array}{c}0.09 \\
(0.06)\end{array}$ & $\begin{array}{l}0.02^{* *} \\
(0.00)\end{array}$ & $\begin{array}{l}0.25 * * \\
(0.04)\end{array}$ \\
\hline Year Fixed Effects & Yes & Yes & Yes & Yes & Yes & Yes \\
\hline $\begin{array}{l}\text { University Fixed } \\
\text { Effects }\end{array}$ & Yes & Yes & Yes & Yes & Yes & Yes \\
\hline $\begin{array}{l}\text { Adoption Cohort } \\
\text { Dummies }\end{array}$ & Yes & No & Yes & No & Yes & No \\
\hline Cons & $\begin{array}{c}-1.00^{* *} \\
(0.27)\end{array}$ & $\begin{array}{l}-9.19 * * \\
(1.82)\end{array}$ & $\begin{array}{c}0.20 \\
(0.16)\end{array}$ & $\begin{array}{l}-0.91 \\
(0.92)\end{array}$ & $\begin{array}{l}-0.15 \\
(0.10)\end{array}$ & $\begin{array}{c}-4.15^{* *} \\
(0.63)\end{array}$ \\
\hline $\mathbf{N}$ & 6,009 & 6,009 & 5,927 & 5,927 & 5,927 & 5,927 \\
\hline
\end{tabular}




\begin{tabular}{|c|c|c|c|c|c|c|}
\hline \multirow[t]{2}{*}{ IMPACT } & \multicolumn{2}{|c|}{$\begin{array}{c}\text { RACIAL/ETHNIC } \\
\text { MINORITY } \\
\text { ENROLLMENT }\end{array}$} & \multicolumn{2}{|c|}{$\begin{array}{c}\text { GRADUATION } \\
\text { RATE | ALL } \\
\mathbf{1 5 0 \%}\end{array}$} & \multicolumn{2}{|c|}{$\begin{array}{c}\text { GRADUATION } \\
\text { RATE | } \\
\text { MINORITY } 150 \%\end{array}$} \\
\hline & (1a) & (1b) & (2a) & (2b) & (3a) & (3b) \\
\hline Within R-Sq & 0.817 & 0.775 & 0,836 & 0.688 & 0.631 & 0.612 \\
\hline
\end{tabular}

\section{Limitations and Future Research}

These estimations indicate no significant average policy effects; however, it is possible that the models are omitting consequences by assuming that there is a uniform effect from the PMS for each year the policy has functioned. The null policy effects found might be attributed to lagged reactions to the policy that appear in the years after initial adoption (Li \& Kennedy, 2018). Future avenues of research should consider accounting for this lag.

My model has some basic assumptions. For example, I assume that the tendencies would have been the same for adopter universities and non-adopter universities in the absence of the PBF. In addition, I expect that these tendencies would be violated if group-specific interventions that also affect performance occur (Hvidman \& Andersen, 2013). Specifically, the model would be violated if more interventions, aside from PBF, were introduced at adopter universities than at non-adopter universities during the period of 2000-2015, particularly if these interventions also affect performance. For example, during this period, the American Recovery and Reinvestment Act of 2009 (ARRA) was enacted. The ARRA provided an opportunity for states to use this one-time federal investment to incentivize their performance, such as degree production (The American Recovery and Reinvestment Act of 2009). Examining this aspect would have strengthened the present study; it is an avenue for future research. 
Future research might consider an in-depth exploration of the relationship between the independent variables that are statistically significant in this model. These variables could include the U.S. News Average, a proxy of the institution's performance, the racial divide, enrollment intensity, and the proportion of state appropriations over total revenue. In addition, further research is needed to account for other actions occurring at the campus level that lead to enhanced performance. The fact that universities adopted a PBF system at different times addresses variable overlap. However, I suggest future investigations on the impact of other policy interventions to better isolate the effect of PBF policies. Lastly, considerations regarding the lag effect should be incorporated into a future study.

Another limitation is that this sample is specific to R1 institutions of higher education. In terms of generalizing the results to the broader public sector, one should be cautious about considering factors that might also play a role in the decision-making process of the sector such as relevant control variables. In addition, future research may consider expanding the panel data set to include the years 2015-2020; more years of performance system data will help researchers further explore the effect of time.

Despite these limitations, the study provides further evidence that PBF systems result in window dressing, or simply a symbol to denote that something is being done. That is, the systems remain somewhat controversial: the general public is made to believe that policy makers care about higher education; however, there is little evidence of tracking to ensure that systems yield the promised results. 


\section{Conclusion}

In conclusion, this analysis expands the literature on performance management systems by studying an essential area of government: higher education. Specifically, the study is helpful because there is a limited number of quantitative, empirical studies in this area. Only 59 were found. The study of the performance-based funding policies is important due to the increased adoption of these types of policies, not only in higher education, but in the overall public sector. Higher education is significant because of the role universities and colleges have in the overall development of society. The findings are concerning because they provide further evidence that there might be too much ado about nothing and that, in fact, these policies might be used as smoke and mirrors and not truly with the intent to exert change.

In this study, I address the research question on whether PBF models impact racial/ethnic minority enrollment, graduation rates for all students, and graduation rates for racial/ethnic minority students at R1 state universities. As a whole, the results suggest that performance-based funding is not generally associated with changes in racial/ethnic minority enrollment, graduation rates, or graduation rates for racial/ethnic minorities. The findings suggest that performance-based funding models do not produce significant results on their own. Universities were hypothesized to experience positive performances after the introduction of a PBF. However, I found little support for this - in only one of the models. I also hypothesized that the universities would experience negative results from the PBFs, and found no support. Lastly, it was hypothesized that there was no effect. In other words, the adoption of a PBF did not produce enhanced performance or 
unintended consequences (negative or positive). There is overwhelming support for this last hypothesis based on the results.

William Bruce Cameron said "not everything that counts can be counted, and not everything that can be counted counts" (Cullis, 2017). PBF, like other performance management policies inspired by NPM principles, emphasizes the measurement of performance. In the case of higher education, several meaningful dimensions are not properly measured and, when counted, are not counted in a meaningful way. The results from this research led me to ask the following questions: Are we truly counting what should be counted? Perhaps what is being counted does not count? Are we leaving out what we should be counting? More importantly, how do we account for what should be counted, or should we stop counting altogether? Have we lost sight of what truly counts by counting what is easy to count? Is this a diversion from what truly counts?

Each of these questions could constitute avenues for future research. Some of these questions can be better assessed with qualitative research tools. From this research alone, based on quantitative analysis, we cannot derive many conclusions - aside from the urgent need for mixed-method analyses to consider all states that have adopted some kind of PBF policy. The number of studies in this area is limited and, when done on a large scale, they do not consider multiple analyzing techniques. 


\section{CHAPTER 5}

\section{Discussion, Implications, and Conclusions}

This dissertation compiled three essays on the topic of performance management systems in public administration. In the two empirical essays, which focused on the adoption and stringency of performance management systems (Chapter 3) and the impact of PMS (Chapter 4), I used the context of higher education to investigate the research questions. The primary link between the three essays was the search for answers - to help us understand the dynamics of PMS. Specifically, in Chapter 2, I conducted a systematic review of the literature to find gaps, themes, goals, and overall limitations of existing research. In Chapter 3, I explored the factors that led to the adoption of a PMS, as well as factors that affected the stringency of the system. Then, in Chapter 4, I focused on the specific case of higher education by exploring the type of impact that occurs after the introduction of a PMS.

The systematic literature review sets the foundation for the two empirical studies in this dissertation. This study uncovered a significant gap in the literature relating to factors affecting adoption (and stringency) and the impact of the PMS. The latter is primarily due to the mixed evidence that is heavily skewed toward non-positive results. Chapter 3 examined this issue from the perspective of the advocates to engage in some accountability mechanism such as PMS. Chapter 4 investigated the other side of the equation-aiming to confirm or refute the mixed findings reported in the literature.

The central goal of this dissertation was to contribute to the literature on performance management systems. Each chapter provides conclusions and a recap of the research questions. The first section of this conclusion will provide a set of limitations of 
this study. Then, I provide a comprehensive summary of the research questions, which is followed by my findings. Because detailed conclusions have already been presented in previous chapters, in this final chapter, I reflect on the major findings of each chapter and discuss how they address the central goal. In addition, I discuss how this dissertation contributes to the literature and the practical implications of these contributions.

\section{Key Findings}

This dissertation examined three interrelated research questions. The first question investigated why some states implement PBF while others do not. The second question investigated why some states adopt more stringent PBF models than others. There has been a lack of research on the impact of PMS. The third research question investigated whether the advertised goals of PMS have been realized in practice.

Utilizing the theoretical frameworks of New Public Management, diffusion (Walker, 1969), and political ideology, I hypothesized that political ideology, underperformance, and geographical diffusion are positively related to the adoption of a performance management system. This model was tested using a logit estimation. As found in the literature, I found evidence that Republicans in office (both Governor and state legislature) are associated with the adoption of a PMS. Moreover, performance was found to be negatively associated with adoption. However, the geographical diffusion hypothesis was not supported.

Utilizing the principal-agent framework, I analyzed the factors that affect stringency. The stringency model was tested using an OLS regression. In this model, the only variable that is significant is the proportion of Republicans in the state legislature. An interesting finding in this model is the effect of time. I find that stringency reaches a 
certain level of plateau, after which it begins to decrease. The model reveals a level of stagnation that could be attributed to issue-fatigue from the principals, or because the associated benefit of the PMS decreases as times passes. This is a novel finding and a contribution to the literature, and it serves as an avenue for future research.

These findings provide evidence that adoption and stringency are not affected by the same factors. While states might act by adopting a PMS, the same factors do not affect the system's configuration.

To explore the impact of the performance management system, three hypotheses were formulated: PMS produces positive outcomes, PMS produces negative outcomes, and PMS produces null outcomes. This model was tested using the DID approach and an OLS regression. The research provides evidence that PMS adoption produces no specific results. This finding expands our knowledge on the impact of these policies. It raises concerns regarding the ongoing debate about accountability mechanisms that are possibly used primarily for symbolic purposes.

The findings from both empirical studies allow us to draw a unified conclusion. Many factors contribute to PMS adoption. In this dissertation, I identify political ideology and performance. Once the PMS is installed, there is an initial, rapid tightening of the system. Next, a tipping point is reached and, at this point, stringency begins to decrease. A plausible cause might be that PMS was adopted to convince constituencies that politicians were acting to solve a problem (i.e., for symbolic purposes). The impact analysis supports this view, because the impact of the PMS is null. 


\section{Measurement and Goal Setting}

In Chapter 2, I found measurement, goal setting, and use of performance information to be critical aspects of a performance management system. A PMS is a multi-dimensional, complex policy mechanism that requires sophisticated mechanisms to function well. The absence of one of these aspects does not negate the PMS. However, the poor design in either one of these aspects will hinder its ability to succeed. Measurement-related factors, in particular, contributed to PMS failure to deliver promises. Measurement is a problem for two reasons: inability to capture intangible outcomes, and inability to fully capture outcomes that are quantifiable.

The literature highlighted two critical factors of a performance system that relate to system configuration: measurement and goal setting. A primary contribution of Chapter 3 is the development of the Performance Funding Uncertainty Index (PFUI). This index aims to capture system configurations to standardize how systems are compared. Because no method had existed to perform such comparisons, I developed the PFUI. The PFUI provides a novel way to assess the level of stringency for PMS in higher education. However, we are still unable to utilize it as a mechanism to assess PMS configurations across sectors (e.g., higher education vs. federal government, etc.). This is an area where we might benefit from future research to holistically assess the stringency level of performance management systems.

PMS is a multidimensional, sophisticated policy tool. However, the presence of a PMS alone is not a decisive factor to effect changes in performance. Equally important to consider is how the system is configured. System configuration directly impacts how organizations subject to the performance system will respond. This is a significant 
finding, because, previously, little attention has been directed toward the specifications of the system. Most of the focus has been on adoption and/or implementation.

Lack of incentives (which are linked to the system configuration) are also found to be a common "scapegoat" to explain why the system fails to deliver. These two are connected to the themes we find in Chapter 3 related to the system stringency.

\section{Time}

Time is a recurring theme. It was cited in the literature as a cause for the system's inability to be effective. The findings in Chapter 3, however, present the time concept from another perspective: to a certain extent, time debilitates the PMS. Time is also a factor in the longitudinal analysis presented in Chapter 4.

Therefore, we should consider time as a common theme in the analysis of this policy tool. First, time should be considered from the perspective of agents. This refers to the amount of time needed for performance to respond to the interventions that emerge from PMS adoption. Second, analysis should be conducted from the perspective of principals. In this case, we see the stringency level of the PMS follows an increasing trajectory. A tipping point is eventually reached, which signals that the initial enthusiasm for PMS has begun to diminish. The increasing trajectory in stringency results in systems that are soft for the initial-stage of adopters; stringency increases as the principals learn through it. The middle-stage adopters face a system that might be reaching its highest level of stringency, and late-stage adopters face a system that is stagnant.

Finally, the third lens through which we can view time is analytical. The time in which adoption occurs matters, not only from the level of stringency perspective, but also from the point of view of evaluating the systems' effectiveness. If institutions adopt the 
same PMS configuration in one state at different points in time, the results might differ. There may be other factors at play (e.g., organizational characteristics might change; implementation strategies might be different).

From the perspective of the agent, how much time is needed before the effectiveness of a PMS can be assessed? From the time the PMS is adopted, to the moment when it is implemented at the organizational level, there are many steps in between. Therefore, it is unrealistic to expect that a PMS will produce yearly impacts beginning with the first year it was adopted. This is an area of future research that can provide best practices to practitioners, policymakers, and agents. It will also provide realistic expectations.

PMS can be viewed as decoration; PMS has been utilized as a symbolic mechanism by policymakers - who must demonstrate action to bolster their re-election hopes - and proponents of PMS - who may view the PMS as a way to validate their decision-making. Having a PMS also gives the impression that something is being done to guarantee results. It will be key to identify the point at which the enthusiasm is lost.

\section{Are we willing to engage in the trade-off between PMS and values?}

The evidence from Chapter 4 indicates that PMS adoption does not produce enhanced outcomes. Concerns have been raised that through PMS adoption, public organizations sacrifice their fundamental democratic values. The field should reach consensus on how to achieve the unfulfilled promise of PMS - to enhance performance.

The reality is that performance management systems are here to stay. Dr. Mark B. Rosenberg, President of Florida International University — an R1 institution and the fourth largest university in terms of enrollment in the United States, described his views 
of PMS as: "we have to make it work, it has to be a win-win." We each have a responsibility to come to the right balance in terms of accounting for intangible outcomes that are not being measured by the PBF. In addition, agents and policymakers must remain true to the mission of their institutions and to the democratic values of their organizations.

Perhaps the benefits associated to PMS are not the enhanced performance effects that one might expect but rather the associated benefits from giving the impression to the constituencies that there are controls in place to keep entities accountable, and these are being verified. In addition to enhancement of performance, changes to the organizational culture, awareness of performance, and a desire to produce results are other benefits associated with a PMS that should not be ignored.

This research contributes to the body of literature in multiple ways. First, it challenges the current knowledge which equates the factors explaining adoption and stringency of performance systems. I argue that these are two separate processes are only loosely connected. Second, I provide a new theoretical explanation for how adopted performance systems evolve over time. Third, I develop a new measure to assess the stringency of performance systems in higher education. Lastly, this dissertation examined the impact of PMS in a specific policy area—-higher education—across the nation.

\section{Implications for Public Policy Making and Management}

As researchers, one of the main goals of embarking in a research venture is to be able to provide meaningful policy advice. The empirical evidence reported in this study shows that performance management systems fail to fulfill their objective (see Chapter 4). The results suggest that PMS do not produce significant results on their own. In this 
sense, policy makers should exercise caution in adoption and implementation of such a costly policy tool such as PBF given its inability to enhance the key performance indicators of public universities mandated by state legislatures.

One could argue that enhancing performance of state universities has not been the real intent behind the adoption of PBF. Rather the goal was more symbolic, seeking to give an impression for change but instead aiming at keeping the status quo. There is no doubt that the decision to adopt PBF for public universities came as a response to the pressures to address the underperformance of state education systems. In this sense, the PBF adoption does serve symbolic purposes- to show constituencies and the general public that system underperformance is a major concern and it has been acted upon. Yet, whether the PBF adoption was mainly a symbolic action or it coincided with legislators' sincere preferences is beyond the scope of this dissertation. Future research could delve into the motivation of individual legislators to provide a better understanding of the politics surrounding the adoption of performance systems, especially those already known for not producing intangible results.

One of the assumptions of this dissertation, underlying the analysis of the PBF systems' stringency, is that agents (i.e., universities) seek to game the system in order to enhance the performance indicators (see chapter 3 under the stringency section). Anecdotal evidence suggest that universities employ various tactics to score better on KPIs. However, this dissertation detects no real improvement in the universities' performance such as graduation rates, which in turns indicates that either there is no significant gaming taking place or, if there are some efforts in this direction, they have not produced much discernible changes. 
From my position of an administrator in a public university, I can attest to the fact that the presence of a performance management system has changed the way we make decisions. In this sense, there might be intangible changes that are not easily quantifiable. For example, in the past, we only focused on the inputs (e.g., number of students enrolled, total number of fundable student credit hours) and paid little attention to student success. The reality is now different. Funding from a performance-based system is the only source of incremental funding we can aspire to have. The eligibility to receive this funding is determined on how well we perform in a set of indicators. In addition, our funding is also jeopardized for underperforming, i.e. our funding is taken away if we fall behind the goal. We, therefore, do not have any other option but to pay attention to student success. Future research should dig deeper into the behavior of individual administrators to better understand the type of changes that are actually taking place, as the changes in institutions' behavior, suggested by the principal-agent theory, do not appear to be supported by the evidence presented in this dissertation.

Further, the introduction of PBF has coincided with aggressive prestige-seeking by public universities. Achieving better rankings, like performance-based funding, requires the attainment of certain performance targets related to student success. In fact, such prestige-seeking activities were in place well before the adoption of a performancebased funding system. It is possible then that these prestige-related efforts have started producing results in terms of student outcomes, thus, wiping out the impact of the adoption of performance-based funding mechanism on the institution's performance. It is a challenge to differentiate between such effects and understand what is truly happening through quantitative tools. Future research could benefit from pursuing a case study that 
will allow to understand the context and the underlying motivation of administrators for pursuing performance improvement: to qualify for funding from the PBF or to enhance the university's ranking.

\section{Limitations}

I will briefly summarize limitations that have previously been cited in the literature, as well as limitations to my own analyses. The systematic literature review, Chapter 2, identified limitations related to the data, including limited population and small samples, measurement of performance, as well as missing important variables. Other limitations are related to statistical techniques, such as reverse causality, and history threats, that is, other events influencing performance at the time of PBF adoption.

The analysis of factors affecting PBF adoption and stringency faced some additional limitations. For example, organizational factors (e.g., characteristics of the bureaucracy) may affect performance. From chapter 3, an important limitation to consider is how diffusion was measured. It seems that regional proximity did not determine whether states would attempt to follow policy trends.

The most important limitation in Chapter 4, which analyzes the impact of a PMS, is related to our inability to determine whether other factors are at play. This is true, however, for any analysis of policy impact. To address this potential flaw, the models control for various alternative explanations, including for fixed effects by year and state. However, this limitation is noteworthy because it was cited in the literature review.

For all analyses presented in this dissertation, the sample population was limited to states with R1 institutions. This might affect our ability to generalize findings to other states and institutions that may not emphasize research as central to their missions. 


\section{Future Research}

In this section, I aimed to develop a future research agenda based on the findings of the present dissertation. I encourage researchers to undertake research efforts that would address the concerns surrounding measurement. Measurement, as I have discussed, is an important aspect of PMS. Measurement affects the system's ability to function. The focus in measurement should be on utilizing the most appropriate indicators to capture the organization's performance. Studies in measurement will also benefit policy makers and governing boards who devise PMS.

In addition, analyzing the effect of time is important. I propose three different perspectives from which future research should study time in PMS. First, time should be evaluated from the perspective that different entry times might affect the level of stringency decided by agents. Which entry point is ideal? Second, time should be studied from the perspective of understanding which factors contribute to the system's stagnation. Lastly, time should be evaluated to understand when it is reasonable to study the impact of a PMS (i.e., after PMS adoption, how much time is needed before a fair evaluation can occur?).

One of the aspects briefly discussed in this dissertation is the high cost associated with the implementation of PMS. I recommend that researchers conduct a thorough study to explore how much PMS costs at each institution and, at the aggregate level, per state. This will allow a true assessment of benefit-cost analysis and provide additional information regarding the trade-offs associated with PMS adoption. In general, the information about cost-effectiveness of PMS implementation is limited (Frank \& D'Souza, 2004). For this reason, a cost-benefit study would be significant. A mixed- 
methods approach would be helpful in order to consider context and intangible aspects of a PMS, which may be neglected if only quantitative approaches are used. Specifically, a case study of a particular institution, or set of institutions, would be useful. In addition, conducting interviews with key stakeholders would provide more information about the context and circumstances surrounding the adoption and implementation of PMS, which would allow for a fair assessment of the benefits and costs associated with a PMS.

This dissertation has discussed the landscape of performance-based funding in higher education. However, the discussion did not include net tuition revenue. It would be irresponsible for me to not mention the serious stress universities are facing due to the consistently decreased growth in tuition revenue. In the case of public institutions, tuition revenue alone does not fully cover the cost of education. Tuition revenue is a critical financial barometer as it is the backbone of most college and university budgets (Seltzer, 2019). Declining tuition revenue has resulted in an increased reliance on state appropriations and performance funding. For this reason, researchers should examine the relationship between PMS adoption and tuition revenue. This would require gathering information from each university. This dissertation uses the state as the unit of measure for the adoption analysis.

Not relevant to this dissertation, but pertinent and timely to higher education, is the topic of student loans. In the United States, total student debt at the end of 2017 was $\$ 1.31$ trillion. The total student debt increases by approximately $\$ 4,000$ per second. A 2016 college graduate for 2016 had an average student debt of $\$ 37,172$ (Fay, n.d.). These are concerning statistics, yet they are not captured by any of the PMS dimensions. Future research should investigate the impact of PMS on student debt levels. Such an 
investigation would reconcile two salient issues: the alarming levels of student debts versus the need to hold institutions of higher education accountable.

This dissertation does not consider the role of organizations which play an important role in the shaping of policies at the state level (such as the American Legislative Exchange Council (ALEC) and other local and national think tanks). A future study may benefit from accounting for how these players affect adoption, in order to map out all possible factors at play when the decision to adopt is made. Lastly, another important factor to consider in the future is the role of rankings. Trends towards prestige pursuing actions have significantly affected the landscape of higher education and, like performance-based funding, some of the ranking criteria requires the achievement of certain levels of performance on student performance indicators. While this study considers the U. S. News Ranking as an independent variable as a proxy of university performance, a study that uses a proxy for ranking as a dependent variable in order to see how it affects adoption of a performance-based funding will be useful. 


\section{REFERENCES}

Adriano, M.N.I. (2014). Quality of governance and local development: The case of top nine performing local government units in the Philippines. Asia Pacific Journal of Multidisciplinary Research, 2(4).

Ammons, D. N. (2001). Performance measurement in North Carolina cities and towns. Popular Government, 67(1), 11-17.

Andersen, S. C. (2008). The impact of public management reforms on student performance in Danish schools. Public Administration, 86(2), 541-558.

Angiola, N., \& Bianchi, P. (2015). Public managers' skills development for effective performance management: Empirical evidence from Italian local governments. Public Management Review, 17(4), 517-542.

Barnow, B. S. (2000). Exploring the relationship between performance management and program impact: A case study of the Job Training Partnership Act. The Journal of the Association for Public Policy Analysis and Management, 19(1), 118-141.

Bashir, M., \& Verma, R. (2019). Internal factors \& consequences of business model innovation. Management Decision.

Battaglio, R. P., \& Hall, J. L. (2018), A Fistful of Data: Unpacking the Performance Predicament. Public Admin Review, 78, 665-668.

Berman, E., \& Wang, X. (2000). Performance measurement in US counties: Capacity for reform. Public Administration Review, 60(5), 409-420.

Berry, F. (1994). Innovation in Public Management: The Adoption of Strategic Planning. Public Administration Review, 54(4), 322-330.

Berry, F. S., \& Berry, W. (1990). State lottery adoptions as policy innovations: An event history analysis. American Political Science Review, 84, 395-416.

Birdsall, C. (2018). Performance management in public higher education: Unintended consequences and the implications of organizational diversity. Public Performance \& Management Review, 41(4), 669-695.

Birdsall, C. (2019). Policy Adoption, Innovation, and Performance Management: The Case of Performance-funding Policies in State Postsecondary Education. State and Local Government Review, 51(1), 34-45.

Bischoff, I., \& Blaeschke, F. (2016). Performance budgeting: Incentives and social waste from window dressing. Journal of Public Administration Research and Theory, 26(2), 344-358. 
Bourdeaux, C., \& Chikoto, G. (2008). Legislative influences on performance management reform. Public Administration Review, 68(2), 253-265.

Burke, J. C. (2002). Funding Public Colleges and Universities for Performance: Popularity, Problems, and Prospects. Albany, NY: Rockefeller Institute Press.

Burke, J. C., \& Henrik, P. M. (2003). Performance reporting: "Real” accountability or accountability "lite": Seventh annual survey 2003. New York City: Nelson A. Rockefeller Institute of Government, State University of New York.

Butler, D., Volden, C., Dynes, A., \& Shor, B. (2017). Ideology, Learning, and Policy Diffusion: Experimental Evidence. American Journal of Political Science, 61(1), $37-49$.

Cameron, A. C., \& Trivedi, P. K. (1990). Regression-based tests for overdispersion in the Poisson model. Journal of econometrics, 46(3), 347-364.

Cavalluzzo, K. S., \& Ittner, C. D. (2004). Implementing performance measurement innovations: evidence from government. Accounting, organizations and society, 29(3-4), 243-267.

Chressanthis, G., Dahan, N., \& Fandl, K. (2015). The Effects of State Pharmacy Drug Product Selection Laws on Statin Patient Generic-To-Branded Drug SwitchBacks. The American Economist, 60(1), 26-51.

Compagni, A., \& Tediosi, F. (2012). Implementing performance-based funding for health research: when governance and procedural fairness matter. Public Administration, 90(2), 313-334.

Cooper, Harris. 2010. Research synthesis and meta-analysis: A step-by-step approach. Thousand Oaks, CA: SAGE Publications.

Courty, P., \& Marshchke, G. (2003). Dynamics of Performance-Measurement Systems. Oxford Review of Economic Policy, 19(2), 268-284. Retrieved from http://www.jstor.org.ezproxy.fiu.edu/stable/23606767

Creswell, J.W., \& Plano Clark, V. L. (2007). Designing and conducting mixed methods research. Thousand Oaks, CA: Sage Publications.

Crow, M., \& Shangraw, R. (2016). Revisiting "public administration as a design science" for the twenty-first century public university. Public Administration Review, 76(5), 762-763.

Cummins, J. (2011). Party Control, Policy Reforms, and the Impact on Health Insurance Coverage in the U.S. States. Social Science Quarterly, 92(1), 246-267. Retrieved from http://www.jstor.org.ezproxy.fiu.edu/stable/42956483 
Cullis, J. O. (2017). Not everything that can be counted counts.... British journal of haematology, 177(4), 505-506.

Darling-Hammond, L., \& Bransford, J. (Eds.). (2007). Preparing teachers for a changing world: What teachers should learn and be able to do. John Wiley \& Sons.

Department of Higher Education and Workforce Development. (2016). State of Missouri Performance Funding for Higher Education. Retrieved from https://dhewd.mo.gov/documents/PerformanceFundingPublicationVo32016.pdf

Destler, K. N. (2016). Creating a performance culture: Incentives, climate, and organizational change. The American Review of Public Administration, 46(2), 201-225.

DiMaggio, P. J., \& Powell, W. W. (2000). The iron cage revisited institutional isomorphism and collective rationality in organizational fields. Economics meets sociology in strategic management, 17, 143-166.

Dimitrijevska-Markoski, T., \& French, P. E. (2019). Determinants of Public Administrators' Use of Performance Information: Evidence from Local Governments in Florida. Public Administration Review, 79(5), 699-709.

Dougherty, K. J., Natow, R. S., Bork, R. H., Jones, S. M., \& Vega, B. E. (2013). Accounting for higher education accountability: Political origins of state performance funding for higher education. Teachers College Record, 115(1), n1.

Dougherty, K. J., \& Natow, R. S. (2019). Analyzing neoliberalism in theory and practice: The case of performance-based funding for higher education.

Dougherty, K. J., \& Reddy, V. T. (2011). The impacts of state performance funding systems on higher education institutions: Research literature review and policy recommendations.

Duke University, Fuqua School of Business. (n.d.). Regression Diagnostics: Testing the Assumptions Of Linear Regression. Retrieved from http://people.duke.edu/ rnau/testing.htm

Durant, R. (2009). Getting dirty-minded: Implementing presidential policy agendas administratively. Public Administration Review, 69(4), 569-585.

Eremin, D. V., Wolf, J. F., \& Woodard, C. A. (2010). Systemic Bias in Federal Performance Evaluations: Does Hierarchy Trump a Performance Management Process? Public Performance \& Management Review, 34(1), 7-21.

Favero, N., \& Rutherford, A. (2019). Will the Tide Lift All Boats? Examining the Equity Effects of Performance Funding Policies in US Higher Education. Research in Higher Education, 61(1), 1-25. 
Fay. (n.d.). Managing Student Loan Debt. Debt.org. Retrieved from https://www.debt.org/students/debt/

Feldman, M., \& March, J. (1981). Information in Organizations as Signal and Symbol. Administrative Science Quarterly, 26(2), 171-186.

Ferlie, E., Musselin, C., \& Andresani, G. (2008). The Steering of Higher Education Systems: A Public Management Perspective. Higher Education, 56(3), 325-348.

Ferris, J. (1992). School-Based Decision Making: A Principal-Agent Perspective. Educational Evaluation and Policy Analysis, 14(4), 333-346. Retrieved from http://www.jstor.org.ezproxy.fiu.edu/stable/1164279.

Florida Board of Governors. Performance-Based Funding. Retrieved from https://www.flbog.edu/finance/performance-based-funding/

Folz, D., Abdelrazek, R., \& Chung, Y. (2009). The Adoption, Use, and Impacts of Performance Measures in Medium-Size Cities: Progress Toward Performance Management. Public Performance \& Management Review, 33(1), 63-87.

Frank, H. A., \& D’Souza, J. (2004). Twelve Years into the Performance Measurement Revolution: Where We Need to Go in Implementation Research. International Journal of Public Administration, 27(8-0), 701-718.

Frederickson, H.G. (2010). Social Equity and Public Administration: Origins, Developments, and Applications. Armonk, NY: M.E. Sharpe

Frølich, N. (2011). Multi-layered accountability. Performance-based funding of universities. Public administration, 89(3), 840-859.

Gerrish, E. (2016). The impact of performance management on performance in public organizations: A meta-analysis. Public Administration Review, 76(1), 48-66.

Gerrish, E. (2017). The effect of the child support performance and incentive act of 1998 on rewarded and unrewarded performance goals. Journal of Policy Analysis and Management, 36(1), 65-96.

Gerrish, E., \& Spreen, T. L. (2017). Does benchmarking encourage improvement or convergence? Evaluating North Carolina's fiscal benchmarking tool. Journal of Public Administration Research and Theory, 27(4), 596-614.

Gill, D., Kengmana, L., \& Laking, R. G. (2012). Statistical Analysis of the Managing for Organizational Performance Survey. Victoria University of Wellington, Institute for Governance and Policy Studies. 
Gilmour, J. B., \& Lewis, D. E. (2005). Assessing performance budgeting at OMB: The influence of politics, performance, and program size. Journal of Public Administration Research and Theory, 16(2), 169-186.

Gilmour, J. B., \& Lewis, D. E. (2006). Does performance budgeting work? An examination of the office of management and budget's PART scores. Public Administration Review, 66(5), 742-752.

Gladwell, M., \& Point, T. (2000). How little things can make a big difference.

Glick, H., \& Hayes, S. (1991). Innovation and reinvention in state policy making: Theory and the evolution of living wills. Journal of Politics, 53(3), 835-850.

Gooden, S. (2014). Race and social equity: A nervous area of government. New York, NY: Routledge.

Gordon, G. (2010). Case studies: Pittsburgh: rebuilding without steel. In E. Berman (Ed.), The formula for Economic Growth on Main Street America (pp. 65-83). Boca Raton, FL: CRC Press.

Guthrie, J., \& Neumann, R. (2007). Economic and non-financial performance indicators in universities: the establishment of a performance-driven system for Australian higher education. Public Management Review, 9(2), 231-252.

Hall, J. L., \& Handley, D. M. (2011). City adoption of federal performance measurement requirements: Perspectives from community development block grant program administrators. Public Performance \& Management Review, 34(4), 443-466.

Hanes, C. M. (2017). Institutional Characteristics that Lead to Increased Student Success Points for Community Colleges in Texas (Doctoral dissertation, Texas A\&M University-Commerce).

Harris, R. (2015). State responses to biotechnology: Legislative action and policymaking in the U.S., 1990-2010. Politics and the Life Sciences, 34(1), 1-27.

Heeks, R. \& Santos, R. (2009). Understanding Adoption of e-Government: Principals, Agents and Institutional Dualism. iGovernment Working Paper Series, No.19/2009. Manchester: Institute for Development Policy and Management. Retrieved from http://www.sed.manchester.ac.uk/idpm/research/publications/wp/di/documents/di -wp36.pdf

Heinrich, C. J. (1999). Do government bureaucrats make effective use of performance management information?. Journal of Public Administration Research and Theory, 9(3), 363-394. 
Heinrich, C. J. (2002). Outcomes-based performance management in the public sector: implications for government accountability and effectiveness. Public Administration Review, 62(6), 712-725.

Heinrich, C. J. (2009). Third-party governance under No Child Left Behind: Accountability and performance management challenges. Journal of Public Administration Research and Theory, 20(suppl_1), i59-i80.

Heinrich, C. J., \& Good, A. (2017). Sustaining a Research Partnership to Improve Educational Outcomes. Researcher-Policymaker Partnerships: Strategies for Launching and Sustaining Successful Collaborations, 132.

Heinrich, C., \& Marschke, G. (2010). Incentives and their dynamics in public sector performance management systems. Journal of Policy Analysis and Management 29(1), 183-208.

Hillman, N. W., Tandberg, D. A., \& Fryar, A. H. (2015). Evaluating the impacts of "new" performance funding in higher education. Educational Evaluation and Policy Analysis, 37(4), 501-519.

Hillman, N. W., Tandberg, D. A., \& Gross, J. P. (2014). Market-based higher education: does Colorado's voucher model improve higher education access and efficiency? Research in Higher Education, 55(6), 601-625.

Ho, A.T.K. (2011). PBB in American local governments: it's more than a management tool. Public Administration Review, 71(3), 391-401.

Holm, J. M. (2018). Successful problem solvers? Managerial performance information use to improve low organizational performance. Journal of Public Administration Research and Theory, 28(3), 303-320.

Hong, S. (2018). A behavioral model of public organizations: Bounded rationality, performance feedback, and negativity bias. Journal of Public Administration Research and Theory, 29(1), 1-17.

Hsiao, C. (2007). Panel data analysis — advantages and challenges. Test, 16(1), 1-22.

Huisman, J., \& Currie, J. (2004). Accountability in higher education: Bridge over troubled water? Higher Education, 48(4), 529-551.

Hvidman, U., \& Andersen, S. C. (2013). Impact of performance management in public and private organizations. Journal of Public Administration Research and Theory, 24(1), 35-58.

IPEDS Data Center. University specific data. Retrieved from https://nces.ed.gov/ipeds/use-the-data 
Jacobides, M., \& Croson, D. C. (2001). Information Policy and Shaping the Value of Agency Relationships. Academy of Management Review, 36(2), 202-223.

Jensen, J. (2003). Policy Diffusion through Institutional Legitimation: State Lotteries. Journal of Public Administration Research and Theory: J-PART, 13(4), 521-541. Retrieved from http://www.jstor.org.ezproxy.fiu.edu/stable/3525660

Julnes, P. D. L., \& Mixcóatl, G. (2006). Governors as agents of change. A comparative study of performance measurement initiatives in Utah and Campeche. Public Performance \& Management Review, 29(4), 405-432.

Kansas Board of Regents. (2011). Performance Agreements: Funding Guidelines. Retrieved from https://www.kansasregents.org/resources/PDF/2441Revised_funding_guidelines_Sept 21 2017.pdf.

Kettl, D. F. (2005). The Global Public Management Revolution. $2^{\text {nd }}$. Washington: Brookings Institution.

King, D., Zeckhauser, R., \& Kim, M. (2002). The management performance of the U.S. states. KSG working paper no. RWP04-028. Retrieved from http://ksghome.harvard.edu

Kioko, S., Marlowe, J., Matkin, D., Moody, M., Smith, D., \& Zhao, Z. (2011). Why Public Financial Management Matters. Journal of Public Administration Research and Theory: J-PART, 21, I113-I124.

Kroll, A. (2015). Lecture title [Regression Diagnostics]. Florida International University, PAD 7705, Applied Quantitative Analysis I.

Kroll, A. (2017). Can performance management foster social equity? Stakeholder power, protective institutions, and minority representation. Public Administration, 95(1), 22-38.

Lam, W. F., \& Wang, X. (2014). The Cognitive Foundation of A Co-Production Approach to Performance Measurement: How Do Officials and Citizens Understand Government Performance in China? Public Administration and Development, 34(1), 32-47.

Lapenta, A., Fattore, G., \& Dubois, H. (2012). Measuring New Public Management and Governance in Political Debate. Public Administration Review, 72(2), 218-227. Retrieved from http://www.jstor.org.ezproxy.fiu.edu/stable/41433296

Lavertu, S., \& Moynihan, D. P. (2012a). Agency political ideology and reform implementation: Performance management in the Bush administration. Journal of Public Administration Research and Theory, 23(3), 521-549. 
Lavertu, S., \& Moynihan, D. P. (2012b). To motivate managers to better use performance data. Journal of Public Administration Research and Theory. 23.

Layne, K., \& Lee, J. (2001). Developing fully functional E-government: A four stage model. Government information quarterly, 18(2), 122-136.

Lee, C., -P., Chang, K., \& Berry, F. S. (2011). Testing the development and diffusion of e-government and e-democracy: A global perspective. Public Administration Review, 71, 444-454.

Legge, C. (2016, May). Gaming Performance Management and Pay. OE Cam. Retrieved from https://www.oecam.com/articles/gaming-performance-management-andpay/

Li, A. Y. (2017). Covet by the Neighbor or "Reverse Policy Diffusion"? State Adoption of Performance Funding 2.0. Research in Higher Education, 58(7), 746-771.

Li, A. Y., \& Kennedy, A. I. (2018). Performance funding policy effects on community college outcomes: Are short-term certificates on the rise? Community College Review, 46(1), 3-39.

Long, J. S., \& Freese, J. (2014). Regression models for categorical dependent variables using Stata. ( $3^{\text {rd }}$ edition ed.) College Station, TX: US: Stata Press.

Lu, Y., Willoughby, K., \& Arnett, S. (2009). Legislating results: Examining the legal foundations of PBB systems in the states. Public Performance \& Management Review, 33(2), 266-287.

Lupton, R., Myers, W., \& Thornton, J. (2017). Party Animals: Asymmetric Ideological Constraint among Democratic and Republican Party Activists. Political Research Quarterly, 70(4), 889-904.

Mansfield University. (2012). Pennsylvania State System of Higher Education 20112017 Performance Funding Program. Retrieved from https://www.mansfield.edu/academic-affairs/upload/PBF-Conceptual-FrameworkDocument-3-30-12-Final-4.pdf

Martin, J. L. (2015). What is ideology?. Sociologia, Problemas e Práticas, (77), 9-31.

Marvel, M. K., \& Marvel, H. P. (2007). Outsourcing oversight: A comparison of monitoring for in-house and contracted services. Public Administration Review, 67(3), 521-530.

Massachusetts Department of Higher Education. (2015). Board of Higher Education Approves Performance Funding Plan for State Universities. Retrieved from https://www.mass.edu/about/newsreleases/nr-20150616.asp. 
Matisoff, D. (2008). The adoption of state climate change policies and renewable portfolio standards: regional diffusion or internal determinants? Review of Policy Research, 25, 527-546.

McKinney, L., \& Hagedorn, L. S. (2015). Performance-based funding for community colleges in Texas: Are colleges disadvantaged by serving the most disadvantaged students? Bryan, TX: Greater Texas Foundation. Chicago.

McLendon, M., Hearn, J., \& Deaton, R. (2006). Called to Account: Analyzing the Origins and Spread of State Performance-Accountability Policies for Higher Education. Educational Evaluation and Policy Analysis, 28(1), 1-24. Retrieved from http://www.jstor.org.ezproxy.fiu.edu/stable/3699540

Meier, L. J., \& Laurence J. O’Toole, Jr. (2006). Bureaucracy in a Democratic State: A Governance Perspective. Baltimore: Johns Hopkins University Press.

Melkers, J. (2006). On the road to improved performance. Public Performance \& Management Review, 30(1), 73-95.

Melkers, J., \& Willoughby, K. (2001). Budgeters' Views of State Performance-Budgeting Systems: Distinctions across Branches. Public Administration Review, 61(1), 5464.

Mintrom, M., \& Vergari, S. (1998). Policy networks and innovation diffusion: The case of state education reforms. The Journal of Politics, 60, 126-148.

Mooney, C. (2001). Modeling regional effects on state policy diffusion. Political Research Quarterly, 54, 103-124.

Moynihan, D. (2005). Goal-Based Learning and the Future of Performance Management. Public Administration Review, 65(2), 203-216.

Moynihan, D. P. (2006). What Do We Talk about When We Talk about Performance? Dialogue Theory and Performance Budgeting. Journal of Public Administration Research and Theory, 16(2), 151-168.

Moynihan, D. (2008). The Dynamics of Performance Management: Constructing Information and Reform. Georgetown University Press.

Moynihan, D. P., \& Kroll, A. (2016). Performance management routines that work? An early assessment of the GPRA Modernization Act. Public Administration Review, 76(2), 314-323.

Moynihan, D. P., \& Lavertu, S. (2012). Does involvement in performance management routines encourage performance information use? Evaluating GPRA and PART. Public Administration Review, 72(4), 592-602. 
Moynihan, D. P., \& Pandey, S. K. (2005). Testing how management matters in an era of government by performance management. Journal of Public Administration Research and Theory, 15, 421-439.

Moynihan, D. P., \& Pandey, S. K. (2010). The big question for performance management: Why do managers use performance information? Journal of Public Administration Research and Theory, 20(4), 849-866.

Moynihan, D., Fernandez, S., Kim, S., LeRoux, K., Piotrowski, S., Wright, B., \& Yang, K. (2011). Performance Regimes Amidst Governance Complexity. Journal of Public Administration Research and Theory: J-PART, 21, I141-I155.

NASBO. National Performance Management Advisory Commission. A Performance Management Framework for State and Local Government. (2010). Retrieved from:

http://www.gfoa.org/sites/default/files/APerformanceManagementFramework.pdf

National Conference of State Legislatures. (2016). Performance-based funding for higher education. Retrieved from http://www.ncsl.org/research/education/performancefunding.aspx

Newcomer, K., \& Caudle, S. (2011). Public Performance Management Systems: Embedding Practices for Improved Success. Public Performance \& Management Review, 35(1), 108-132.

Nisar, M. (2015). Higher education governance and performance-based funding as an ecology of games. Journal of Higher Education, 69, 289-302.

Norris, D. F., \& Moon, J. (2005). Advancing e-government at the grassroots: tortoise or hare? Public Administration Review, 65, 64-75.

O'meara, K. (2007). Striving for what? Exploring the pursuit of prestige. In Higher education: Handbook of theory and research (pp. 121-179). Springer, Dordrecht.

Office of the Washington State Auditor. (2014). Performance Audit. Higher Education Performance-Based Funding. A prospective analysis of performance funding in other states to inform options for public four-year higher education institutions in Washington. Retrieved from https://portal.sao.wa.gov/ReportSearch/Home/ViewReportFile?isFinding=false\&a $\underline{\mathrm{rn}=1011502}$

Oklahoma State Regents for Higher Education. (2018). Report on the Future of Higher Education. Retrieved from https://www.okhighered.org/future/docs/finalreport.pdf. 
Onesti, T., Angiola, N., \& Bianchi, P. (2016). Learning by using performance measures in local governments: The perspective of public managers. Public Administration Quarterly, 842-881.

Ozdem, G. (2011). An analysis of the mission and vision statements on the strategic plans of higher education institutions. Educational Sciences: Theory and Practice, 11(4), 1887-1894.

Pasha, O. (2018). Can performance management best practices help reduce crime? Public Administration Review, 78(2), 217-227.

Patrick, B., \& Rollins, A. (2015). Assessing Public Sector Performance Reforms and the Plight of Disadvantaged Citizens. Public Administration Quarterly, 39(4), 697733.

Perrow, C. (1986). Complex Organizations: A Critical Essay. New York: Random House.

Pew Research Center (2019). Two Decades of Change in Federal and State Higher Education Funding. Recent trends across levels of government. Retrieved from https://www.pewtrusts.org/en/research-and-analysis/issue-briefs/2019/10/twodecades-of-change-in-federal-and-state-higher-education-funding

Poister, T. H. (2003). Measuring performance in public and nonprofit organizations. San Francisco, CA: Jossey-Bass.

Poister, T. H., Pasha, O. Q., \& Edwards, L. H. (2013). Does performance management lead to better outcomes? Evidence from the US public transit industry. Public Administration Review, 73(4), 625-636.

Poister, T. H., Pasha, O., DeGroff, A., \& Royalty, J. (2018). The impact of performancebased grants management on performance: The Centers for Disease Control and Prevention's national breast and cervical cancer early detection program. The American Review of Public Administration, 48(5), 444-457.

Pollitt, C. (2000) 'Is the Emperor in His Underwear?' An Analysis of the Impacts of Public Management Reform. Public Management, 2(2), 181-199.

Rabovsky, T. (2012). Accountability in Higher Education: Exploring Impacts on State Budgets and Institutional Spending Patterns. Journal of Public Administration Research and Theory: J-PART, 22(4), 675-700.

Rabovsky, T. (2014a). Support for performance-based funding: The role of political ideology, performance, and dysfunctional information environments. Public Administration Review, 74(6), 761-774. 
Rabovsky, T. M. (2014b). Using data to manage for performance at public universities. Public Administration Review, 74(2), 260-272.

Rabovsky, T., \& Rutherford, A. (2016). The Politics of higher education: University president ideology and external networking. Public Administration Review, 76(5), 764-777.

Radin, B. A. (2006). Challenging the performance movement: Accountability, complexity, and democratic values. Georgetown University Press.

Rivenbark, W. C., Fasiello, R., \& Adamo, S. (2019). Exploring Performance Management in Italian Local Government: The Necessity of Outcome Measures and Citizen Participation. The American Review of Public Administration, 49(5), $545-553$.

Roberts, M. (2016). Differences in Differences (DD) Empirical Methods [Power Point Slides]. Retrieved from http://finance.wharton.upenn.edu/ mrrobert/resources/Teaching/CorpFinPhD/Dif$\underline{\text { In-Dif-Slides.pdf }}$

Rutherford, A., \& Rabovsky, T. (2014). Evaluating student outcomes in higher education. The ANNALS of the American Academy of Political and Social Science, 655(1), (185-208).

Sanger, M. B. (2013). Does Measuring Performance Lead to Better Results? Journal of Policy Analysis and Management, 185-203.

Seltzer, R. (2019, November 12). Tuition Revenue Growth Expected to Slow. Retrieved from https://www.insidehighered.com/quicktakes/2019/11/12/tuition-revenuegrowth-expected-slow

Selviaridis, K., \& Norrman, A. (2015). Performance-based contracting for advanced logistics services: Challenges in its adoption, design and management. International Journal of Physical Distribution \& Logistics Management, 45(6), $592-617$.

SHEEO State Higher Education Finance (SHEF) Data for expenditures and educational appropriations. Retrieved from http://www.sheeo.org/resources

Shin, J. C. (2010). Impacts of performance-based accountability on institutional performance in the U.S. Higher Education, 60(1), 47-68

Shipan, C. R., \& Volden, C. (2006) Bottom-up federalism: The diffusion of antismoking policies from U.S. cities to states. American Journal of Political Science, 50, 825843. 
Shipan, C., \& Volden, C. (2012). Policy Diffusion: Seven Lessons for Scholars and Practitioners. Public Administration Review, 72(6), 788-796.

Shulman, L. S. (2001). The Carnegie classification of institutions of higher education. Menlo Park: Carnegie Publication.

Sohn, H., \& Bae, K. B. (2018). Do public employees “Game” performance budgeting systems? Evidence from the program assessment rating tool in Korea. The American Review of Public Administration, 48(5), 458-475.

Soiferman, L. K. (2010) Compare and Contrast Inductive and Deductive Research Approaches. Online Submission. Retrieved from: https://files.eric.ed.gov/fulltext/ED542066.pdf

Soss, J., Fording, R., \& Schram, S. F. (2011). The organization of discipline: From performance management to perversity and punishment. Journal of Public Administration Research and Theory, 21(suppl_2), i203-i232.

StataCorp. 2019. Stata Statistical Software: Release 16. College Station, TX: StataCorp LLC.

StataCorp. 2013. Stata 13 Base Reference Manual. College Station, TX: Stata Press.

State of Arkansas. (2017). Arkansas Department of Higher Education Outcomes-Based Funding 'Report Card' for Arkansas Public Colleges and Universities Fiscal Year 2017-18. Retrieved from https://static.ark.org/eeuploads/adhe/3 Performance Funding Outcomes (Combined).pdf

Sun, R., \& Van Ryzin, G. G. (2014). Are Performance Management Practices Associated with Better Outcomes? Empirical Evidence From New York Public Schools. The American Review of Public Administration, 44(3), 324-338.

Tabachnick, B. G., Fidell, L. S., \& Ullman, J. B. (2007). Using multivariate statistics (Vol. 5). Boston, MA: Pearson.

Tandberg, D., \& Hillman, N. (2014). State Higher Education Performance Funding: Data, Outcomes, and Policy Implications. Journal of Education Finance, 39(3), $222-$ 243.

The American Recovery and Reinvestment Act of 2009: Saving and Creating Jobs and Reforming Education. (2009, March 11). Retrieved from https:/www2.ed.gov/policy/gen/leg/recovery/implementation.html

The Carnegie Classification of Institutions of Higher Education. (2018). News \& Announcements 2018 Classification Update. Retrieved from https://carnegieclassifications.iu.edu 
Thomas, V. L. (2001). Restoring Government Integrity through Performance, Results, and Accountability. In D. Forsythe (Ed.), Quicker, Better, Cheaper? Managing Performance in American Government (pp.113-142). Albany, NY: Rockefeller Institute Press.

Todd, K., \& Anderson, D. (2016). The Multidimensional Consequences of Disruption in Higher Education. Public Administration Review, 76(5), 821-822.

Treier, S., \& Hillygus, D. (2009). The Nature of Political Ideology in the Contemporary Electorate. The Public Opinion Quarterly, 73(4), 679-703.

U.S. Bureau of Labor Statistics. Data for unemployment. Retrieved from https://www.bls.gov/sae/tables.htm

U.S. Census Bureau. Data for population. Retrieved from https://www.census.gov/programs-surveys/popest/data/tables.html

U.S. Department of Education, National Center for Education Statistics, Common Core of Data (CCD). (2018). "Public Elementary/Secondary School Universe Survey," 1989-90 through 2015-16; Private Schools in American Education; Statistics of Public Elementary and Secondary Day Schools, 1980-81; Schools and Staffing Survey (SASS), "Private School Data File," 1990-91; Private School Universe Survey (PSS), 1995-96 through 2015-16; Higher Education General Information Survey (HEGIS), "Institutional Characteristics of Colleges and Universities" survey, 1980-81; Integrated Postsecondary Education Data System (IPEDS), "Institutional Characteristics Survey" (IPEDS-IC:90-99); and IPEDS Fall 2001 through Fall 2015, Institutional Characteristics component. Retrieved from https://nces.ed.gov/programs/digest/d17/tables/dt17 105.50.asp

Utah Foundation. (2014). Steps Forward in Higher Ed: Success Measures, Game Changers, and Performance-Based Funding in Utah. Retrieved from http://www.utahfoundation.org/reports/performance-based-funding-in-utahshigher-education/.

Van Dooren, W. (2011). Better performance management: Some single-and double-loop strategies. Public Performance \& Management Review, 34(3), 420-433.

Van Dooren, W., \& Van de Walle, S. (2008). Reality is merely an illusion, albeit a persistent one: introduction to the performance measurement symposium.

Vogel, R., \& Hattke, F. (2018). How is the use of performance information related to performance of public sector professionals? Evidence from the field of academic research. Public Performance \& Management Review, 41(2), 390-414.

Walker, J. L. (1969). The diffusion of innovations among the American states. American Political Science Review, 63(3), 880-889. 
Walker, R. M., Damanpour, F., \& Devece, C. A. (2011). Management innovation and organizational performance: The mediating effect of performance management. Journal of Public Administration Research and Theory, 21(2), 367-386.

Walker, R. M., Jung, C. S., \& Boyne, G. A. (2013). Marching to different drummers? The performance effects of alignment between political and managerial perceptions of performance management. Public Administration Review, 73(6), 833-844.

Walker, R., Boyne, G., Brewer, G., \& Avellaneda, C. (2011). Market Orientation and Public Service Performance: New Public Management Gone Mad? Public Administration Review, 71(5), 707-717.

Wang, W., \& Yeung, R. (2019). Testing the Effectiveness of "Managing for Results": Evidence from an Education Policy Innovation in New York City. Journal of Public Administration Research and Theory, 29(1), 84-100.

Wooldridge, B., \& Gooden, S. (2009). The Epic of Social Equity. Administrative Theory \& Praxis, 31(2), 222-234. doi:10.2753/ATP1084-1806310205

Yang, K., \& Hsieh, J. Y. (2007). Managerial effectiveness of government performance measurement: testing a middle-range model. Public Administration Review, 67(5), 861-879.

Yang, K., \& Kassekert, A. (2010). Linking management reform with employee job satisfaction: Evidence from federal agencies. Journal of Public Administration Research and Theory, 20(2), 413-436.

Yi, H., Berry, F., \& Chen, W. (2019). Management Innovation and Policy Diffusion through Leadership Transfer Networks: An Agent Network Diffusion Model. Journal of Public Administration Research and Theory, 28(4), 457-474. 


\section{APPENDICES}

TABLE A1. Other Measures, Chapter 3

\begin{tabular}{|c|c|}
\hline Measure (source) & Description \\
\hline $\begin{array}{l}\text { Number of years PBF Present } \\
\text { (NCLS Database) }\end{array}$ & $\begin{array}{l}\text { Measures the number of years the PBF is present } \\
\text { for each state }\end{array}$ \\
\hline $\begin{array}{l}\text { Average U.S. News Ranking (U.S. } \\
\text { News Survey) }\end{array}$ & $\begin{array}{l}\text { U.S. News surveys top academics - presidents, } \\
\text { provosts and deans of admissions - asking them to } \\
\text { rate the academic quality of peer institutions with } \\
\text { which they are familiar on a scale of } 1 \text { (marginal) } \\
\text { to } 5 \text { (distinguished). Academic reputation matters } \\
\text { because it factors things that cannot easily be } \\
\text { captured elsewhere. For example, an institution } \\
\text { known for having innovative approaches to } \\
\text { teaching may perform especially well on this } \\
\text { indicator, whereas a school struggling to keep its } \\
\text { accreditation will likely perform poorly. }\end{array}$ \\
\hline $\begin{array}{l}\text { Governor's party affiliation } \\
\text { (Election Yearbook for the United } \\
\text { States) }\end{array}$ & $\begin{array}{l}\text { Binary variable coded as } 1 \text { if the governor's party } \\
\text { is Republican and } 2 \text { if it is Democrat. }\end{array}$ \\
\hline $\begin{array}{l}\text { Percent of republicans in state } \\
\text { legislature (Election Yearbook for } \\
\text { the United States) }\end{array}$ & $\begin{array}{l}\text { Total number of Republican legislators divided by } \\
\text { the total numbers of seats in the legislature. }\end{array}$ \\
\hline $\begin{array}{l}\text { Diffusion (Election Yearbook for } \\
\text { the United States) }\end{array}$ & $\begin{array}{l}\text { Ratio of Neighboring States with PBF over Total } \\
\text { number of Neighboring States }\end{array}$ \\
\hline
\end{tabular}


Appendix A2. Regression Diagnostics

\section{Linearity}
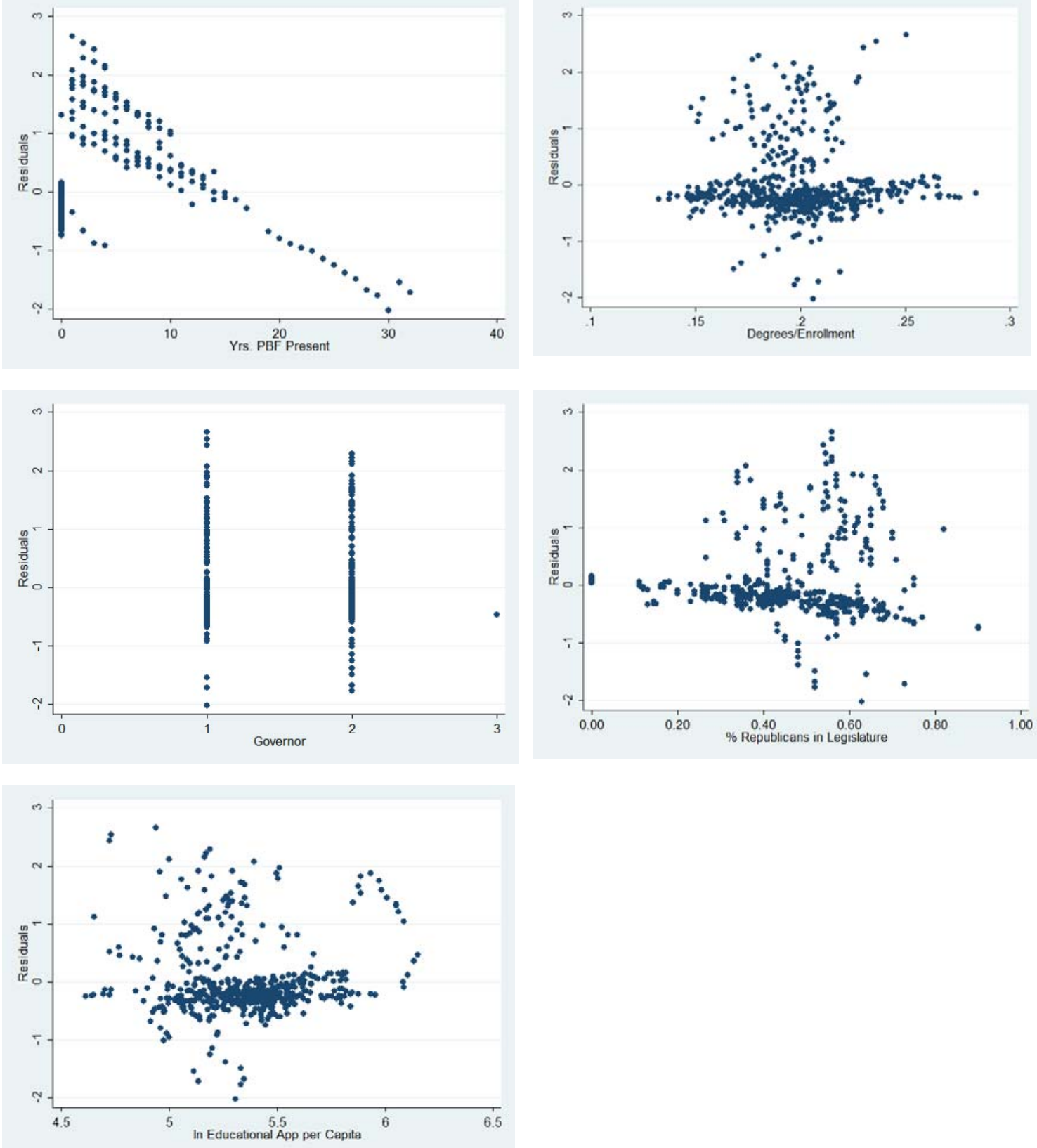


\section{Normality}

Kernel Density Estimate

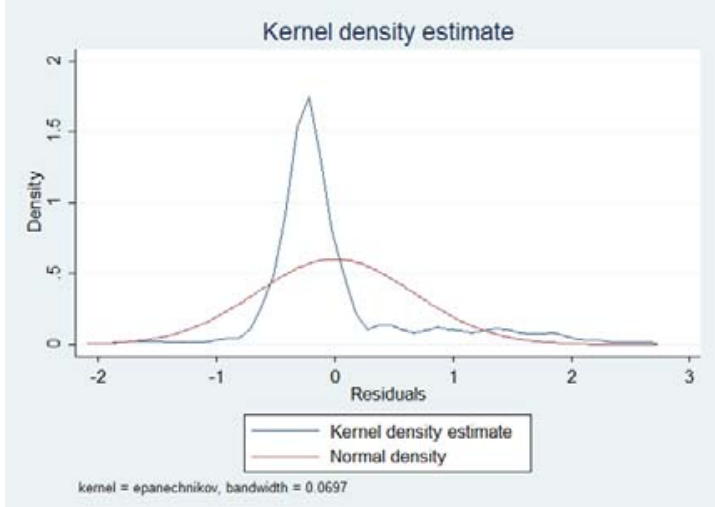

Normal Quantile Plot

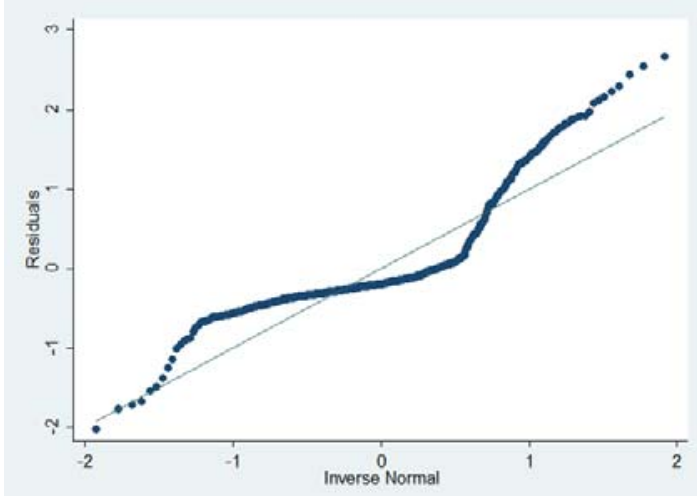

\section{Homoscedasticity}

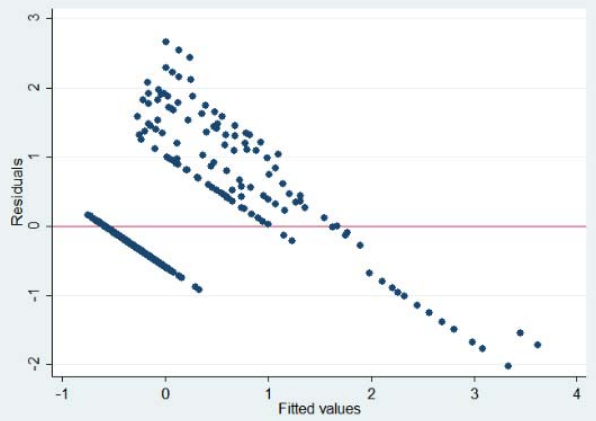

Normal Probability Plot

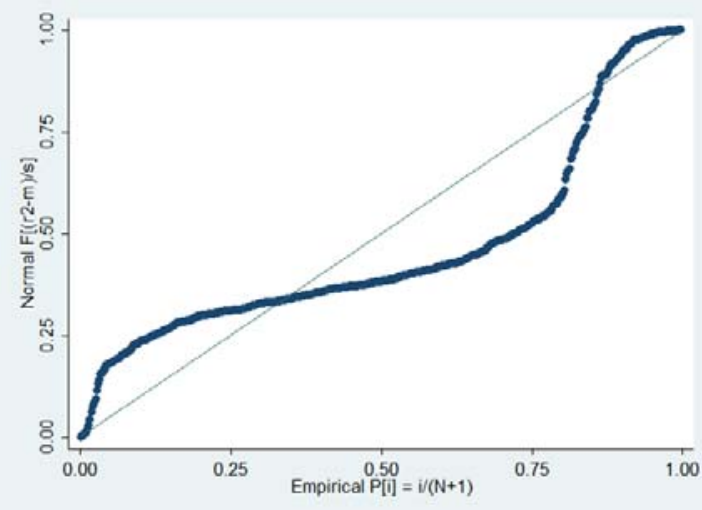




\section{Outlier}
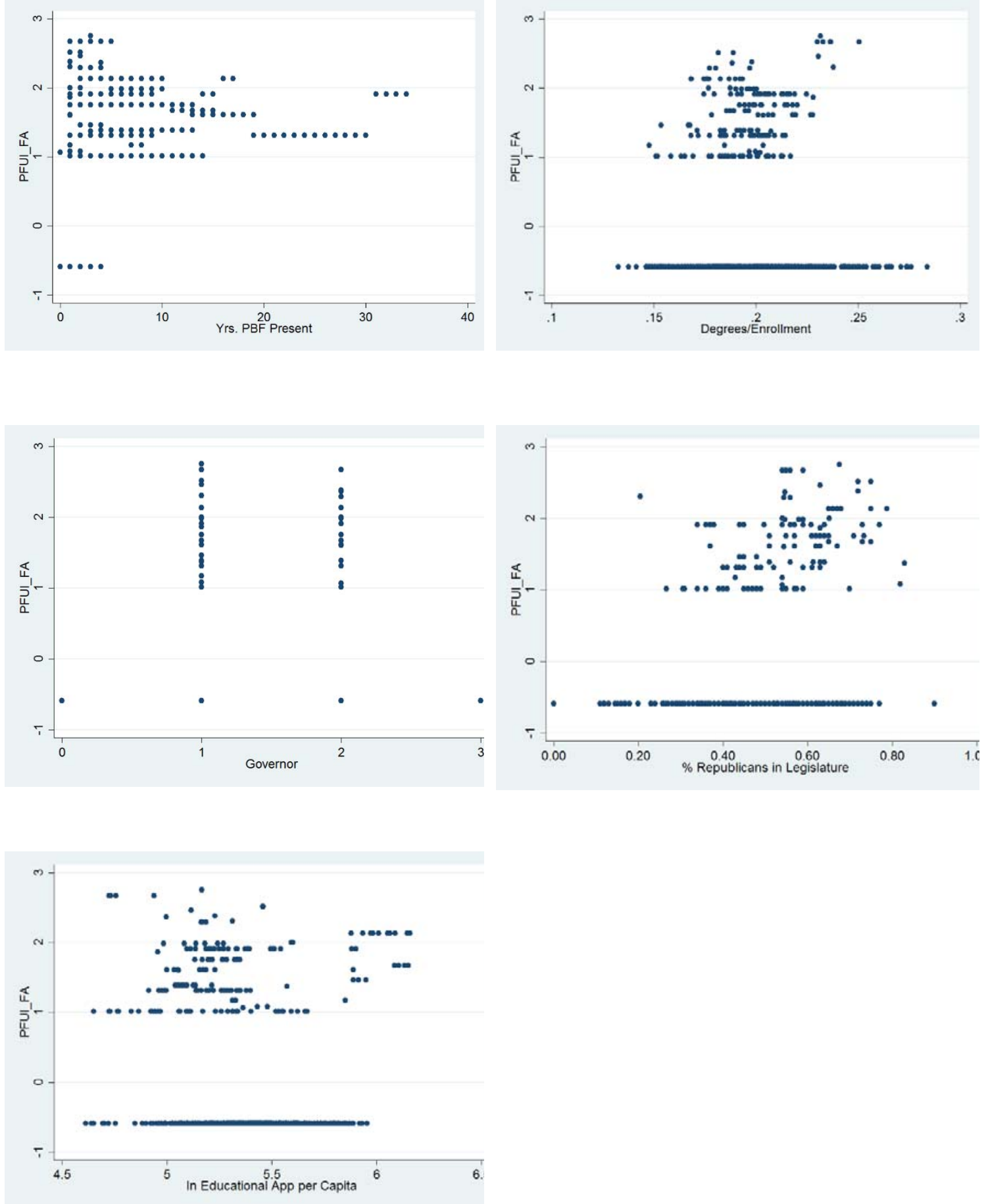


\section{Multicollinearity}

Adoption Model

. vif

\begin{tabular}{|c|c|c|}
\hline Variable & VIF & $1 / \mathrm{VIF}$ \\
\hline USNewsPeer e & 1.48 & 0.673993 \\
\hline ofNeighbor F & 1.62 & 0.618328 \\
\hline Republican e & 1.60 & 0.623436 \\
\hline Governor & 1.25 & 0.801671 \\
\hline TotalNumbe s & 1.73 & 0.576982 \\
\hline Unemp loyme e & 3.42 & 0.292467 \\
\hline PITotalRev e & 1.68 & 0.595051 \\
\hline SalesTaxRe e & 1.69 & 0.593235 \\
\hline HighEdExpT s & 2.38 & 0.420876 \\
\hline Midwest & 2.30 & 0.435393 \\
\hline Northeast & 3.24 & 0.309016 \\
\hline $\begin{array}{r}\text { South } \\
\text { Year }\end{array}$ & 2.76 & 0.361810 \\
\hline 2001 & 2.00 & 0.501016 \\
\hline 2002 & 2.07 & 0.483513 \\
\hline 2003 & 2.01 & 0.498654 \\
\hline 2004 & 2.01 & 0.496973 \\
\hline 2005 & 1.96 & 0.510290 \\
\hline 2006 & 1.94 & 0.516777 \\
\hline 2007 & 1.94 & 0.515526 \\
\hline 2008 & 2.42 & 0.414051 \\
\hline 2009 & 3.53 & 0.283281 \\
\hline 2010 & 3.23 & 0.309488 \\
\hline 2011 & 2.84 & 0.352200 \\
\hline 2012 & 2.68 & 0.372692 \\
\hline 2013 & 2.41 & 0.414620 \\
\hline 2014 & 2.26 & 0.443274 \\
\hline 2015 & 2.24 & 0.446458 \\
\hline Mean VIF & 2.25 & \\
\hline
\end{tabular}

Stringency Model

. vif

\begin{tabular}{r|rr} 
Variable & VIF & $1 /$ VIF \\
\hline YrsPBFPres t & $\mathbf{8 . 4 8}$ & 0.117985 \\
c. & & \\
YrsPBFPres t\# & & \\
c. & & \\
YrsPBFPres t & 12.46 & 0.080281 \\
USNewsPeer e & 1.60 & 0.626574 \\
ofNeighbor F & 1.24 & 0.807297 \\
Republican e & 1.51 & 0.663484 \\
Governor & 1.20 & 0.834389 \\
Unemployme e & 1.07 & 0.938101 \\
PITotalRev e & 1.91 & 0.524824 \\
SalesTaxRe e & 5.59 & 0.178982 \\
HighEdExpT s & 2.10 & 0.475611 \\
Midwest & 1.84 & 0.542431 \\
Northeast & $\mathbf{2 . 1 9}$ & 0.456900 \\
South & $\mathbf{2 . 2 3}$ & 0.448440 \\
\hline Mean VIF & $\mathbf{3 . 3 4}$ &
\end{tabular}


TABLE A1: Other Measures, Chapter 4

\begin{tabular}{|l|l|}
\hline \multicolumn{1}{|c|}{ Measure (source) } & \multicolumn{1}{|c|}{ Description } \\
\hline Racial Diversity & Percent of undergraduates who are White. \\
\hline Enrollment Intensity of Students & Percent of part-time students. \\
\hline $\begin{array}{l}\text { Average U.S. News Ranking (U.S. } \\
\text { News Survey) }\end{array}$ & $\begin{array}{l}\text { U.S. News surveys top academics - presidents, } \\
\text { provosts and deans of admissions - asking them } \\
\text { to rate the academic quality of peer institutions } \\
\text { with which they are familiar on a scale of 1 } \\
\text { (marginal) to 5 (distinguished). Academic } \\
\text { reputation matters because it factors things that } \\
\text { cannot easily be captured elsewhere. For } \\
\text { example, an institution known for having } \\
\text { innovative approaches to teaching may perform } \\
\text { especially well on this indicator, whereas a } \\
\text { school struggling to keep its accreditation will } \\
\text { likely perform poorly. }\end{array}$ \\
\hline
\end{tabular}


VITA

\section{LILIA SILVERIO MINAYA}

Born, Santiago, Dominican Republic

2001-2005

2005-2007

$2007-2008$

2007-2012

B.A., Economics

Florida International University

Miami, Florida

Coordinator, Administrative Services

Florida International University, College of Engineering Miami, Florida

M.S., Finance

Florida International University

Miami, Florida

Assistant Director, Research Programs

Florida International University, College of Engineering Miami, Florida

2008-2009

Member, Educational Leadership Enhancement Program Florida International University

Miami, Florida

2012-2016

Director, Finance and Human Resources

Florida International University, CARTA

Miami, Florida

2015

Member, FIUBeyondPossible2020, Build Financial Base and Operational Efficiencies Committee

Florida International University

Miami, Florida

2015-2017

Doctoral Candidate, Public Affairs

Florida International University

Miami, Florida

2016-2018

Executive Director, Operations

Florida International University, CARTA

Miami, Florida

2017

Student Representative, PhD Committee, Department of

Public Policy and Administration 
Florida International University

Miami, Florida

2018

Member, FIU's Next Horizon 2025 Strategic Plan, Course

Planning Working Group

Florida International University

Miami, Florida

2018-2019

Elected Board Member

American Society of Public Administration

Miami, Florida

2018-2019

Member, Search and Screen Committees

Tenure Earning Faculty, Department of Public Policy and Administration; Executive Director, College of Business;

Executive Director Miami Urban Futures Initiative, Florida International University

Miami, Florida

2018-Present

Assistant Dean of Student Services and Strategic Planning and Executive Director of Finance and Human Resources Florida International University, CARTA Miami, Florida

2020

Member, Presidential Leadership Program

Florida International University

Miami, Florida

\section{PUBLICATIONS AND PRESENTATIONS}

Silverio-Minaya, L. (March, 2019). Determinants of Adoption and Stringency of Performance-based Funding in the United States: The Case of Higher Education. Paper presented at the conference of the American Society of Public Administration. Washington, D. C.

Silverio-Minaya, L. (November, 2018). Budget Uncertainty and Access to Higher Education: Implications of Performance-based Funding in U.S. States. Paper presented at the conference of the Association for Budgeting and Financial Management. Denver, Colorado.

Silverio-Minaya, L. (March, 2017). Assessing Performance Funding in Higher Education. Paper presented at the conference of the American Society of Public Administration. Atlanta, Georgia. 